Georgetown University Law Center

Scholarship @ GEORGETOWN LAW

2000

Restoring What's Environmental About Environmental Law in the Supreme Court

Richard J. Lazarus

Georgetown University Law Center, lazarusr@law.georgetown.edu

This paper can be downloaded free of charge from:

https://scholarship.law.georgetown.edu/facpub/157

47 U.C.L.A. L. Rev. 703-812 (2000)

This open-access article is brought to you by the Georgetown Law Library. Posted with permission of the author.

Follow this and additional works at: https://scholarship.law.georgetown.edu/facpub

Part of the Environmental Law Commons, and the Jurisprudence Commons 


\section{GEORGETOWN LAW Faculty Publications}

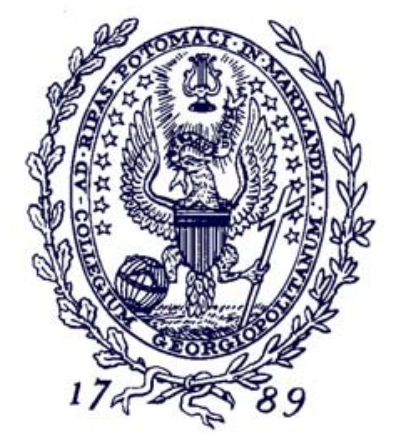

January 2010

\section{Restoring What's Environmental About Environmental Law in the Supreme Court}

47 U.C.L.A. L. Rev.703-812 (2000)

Richard J. Lazarus

Professor of Law

Georgetown University Law Center

lazarusr@law.georgetown.edu

This paper can be downloaded without charge from:

Scholarly Commons: http://scholarship.law.georgetown.edu/facpub/157/

SSRN: $\underline{\text { http: } / / \text { ssrn.com/abstract }=216433}$

Posted with permission of the author 


\title{
RESTORING WHAT'S ENVIRONMENTAL ABOUT ENVIRONMENTAL LAW IN THE SUPREME COURT
}

\author{
Richard J. Lazarus*
}

In this Article, Professor Richard Lazarus examines the votes of the individual Justices who have decided environmental law cases before the United States Supreme Court during the past three decades. The Article reports on a number of interesting statistics regarding the identity of those Justices who have most influenced the Court's environmental law jurisprudence and the sometimes curious patterns in voting exhibited by individual Justices. Lazarus's thesis is that the Supreme Court's apparent apathy or even antipathy towards environmental law during that time results from the Justices' failure to appreciate environmental law as a distinct area of law. The Justices have instead tended to view environmental protection as merely an incidental factual context for the presentation of legal issues that share no unique environmental dimension.

Lazarus posits that this view of environmental law is misguided and that it has resulted in poorer Court decisions. Missing from the Court's analysis has been sufficient emphasis on the nature and normative weightiness of environmental protection concerns and their import both for judicial construction of relevant legal rules and for the Court's understanding of the workings of relevant laumaking institutions. Finally, Lazarus describes how the environmental dimension to environmental law might be restored to the nation's highest Court. This discussion includes a description of how the ecological character of the problem addressed by environmental law affects legal doctrine and lawmaking institutions and how current and future Justices might be made better aware of that relationship.

INTRODUCTION

I. THREE DECADES OF ENVIRONMENTAL LAW IN THE SUPREME COURT:

A SCORECARD OF WHO WROTE, WHOSE VIEWS PREVAILED, AND HOW, IF AT ALL, DID THE ENVIRONMENT INFLUENCE

THE VOTES OF INDIVIDUAL JUSTICES

* John Carroll Research Professor of Law, Georgetown University Law Center. Special thanks are owed to Georgetown University law students Staci Krupp, Tom Shebar, Alex Steffan, and Stephanie Tai, who provided excellent research assistance in the preparation of this Article, and to Jeannette Austin and Professors Hope Babcock, Peter Byrne, Lisa Heinzerling, Maxine Lipeles, Christopher Schroeder, Dan Tarlock, and Mark Tushnet, who commented on earlier drafts. Thanks are also owed to Professor David Sive of the Pace Law School, who first prompted me to undertake this inquiry in response to his invitation to deliver the 1999 Lloyd K. Garrison Lecture at Pace, to be published in the Pace Environmental Law Review, as well as the law faculties of both Pace and Washington University who commented on prior versions. To the extent that the Article discusses Supreme Court decisions in several cases in which I served as counsel for parties involved in the litigation, the views expressed are my own and do not necessarily reflect the views of those parties 1 represented. 
A. The Justices Who Wrote the Most Environmental Decisions for the Court. 708

B. The Justices Who Were Most Often in the Majority in Environmental Cases

C. Scoring the Justices on Environmental Protection 715

1. For Most of the Justices the Environmental Protection Dimension of a Case Before the Court Does Not Influence Their Vote.

2. The Voting Records of a Few Justices Suggest that the Environmental Protection Dimension of a Case Affected Their Resolution of the Legal Issue Before the Court

3. The Individual Voting Records of the Justices in Environmental Cases Suggest an Overall Trend Towards Environmental Concerns' Being Less Favored by the Court

II. THE JUSTICES' APATHY AND POSSIBLE ANTIPATHY TOWARDS

ENVIRONMENTAL PROTECTION: REFLECTIONS ON THE NATURE OF ENVIRONMENTAL LAW

III. RESTORING WHAT'S ENVIRONMENTAL ABOUT

ENVIRONMENTAL LAW

A. What Is Environmental About Environmental LawThe Nature of Environmental Injury

B. Challenges for Law and Lawmaking. 748

1. Legal Doctrine 749

2. Lawmaking Institutions and Processes ................................................... 759

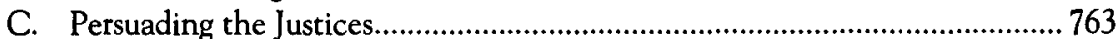

CONCLUSION 771

APPENDIX A 773

APPENDIX B. 784

APPENDIX C 786

APPENDIX D .812

\section{INTRODUCTION}

The United States Supreme Court's treatment of environmental law presents a puzzle. Few would likely dispute the historical thesis that the judiciary's active promotion of environmental protection in the 1960s and early 1970 s played a major role in the emergence of that remarkable series of far-reaching statutory enactments that constitute modern environmental law. Nor would there be much dispute regarding the assertion that those statutory enactments, whatever one's views of their efficacy, represent one of the most ambitious legislative and executive branch undertakings of the past half-century. 
The puzzle nonetheless presented concerns the sharply contrasting role played by the Supreme Court during this remarkable period of legal evolution. In other comparable legal transformations, such as those that occurred during the twentieth century in antitrust, civil rights, labor, and securities law, the Court has been actively engaged in the law's development. The Court's docket reflects its willingness and interest in addressing the host of legal issues invariably raised by the introduction of a wholly new field of law. And, at least since the New Deal, the Court has generally been more responsive than openly hostile to the new values and priorities reflected in these statutory enactments in other areas of law, notwithstanding that their translation and application to specific contexts may engender much disagreement and controversy between the Justices.

The Court's response to environmental law during the past three decades, however, has been decidedly different. One commentator, based on his review of the Court's environmental rulings, recently concluded that "the Court has either stayed on the sidelines or participated ineffectually in the making of environmental law." Two other commentators, upon reviewing sixty-seven Court rulings from 1960 to 1988 , found that the Court, rather than exhibiting any receptivity to environmental law's basic precepts, had been openly and actively hostile in its rulings. ${ }^{2}$

The purpose of this Article is to explore the Supreme Court's apparent apathy or antipathy towards environmental law. The data set of cases considered is much larger - by a factor of almost four-than those of prior academic inquiries. This is partly because those inquiries were each performed several years ago and the Court has since decided many more cases. But it is also much larger because it includes as environmental cases the Court's natural resource cases and not simply the classic pollution control cases.

What most distinguishes this inquiry from those conducted in the past is that this Article deliberately declines to entertain the traditional analytic fiction that the Court is a monolithic institution, the actions of which commentators must therefore strive to explain presuming the existence of a single unified, coherent lawmaking entity. The Article seeks instead to understand the role of the Supreme Court in environmental law by piercing that fictitious judicial veil surrounding the Court's decision making to consider the votes and possible motivations of the nineteen individual Justices who have

1. Daniel A. Farber, Is the Supreme Court Irrelevant?: Reflections on the Judicial Role in Environmental Law, 81 MINN. L. REV. 547, 569 (1997).

2. See Richard E. Levy \& Robert L. Glicksman, Judicial Activism and Restraint in the Supreme Court's Environmental Law Decisions, 42 VAND. L. REV. 343, 421 (1989) (stating that the Court "demonstrates ... a consistent pro-development pattern ... since 1976," and that "these decisions reflect policy activism by the Court"). 
served on the Court since October Term 1969 and who have formed the shifting majority coalitions underlying its environmental rulings.

Environmental protection is far more challenging for law than it might seem. The very nature of the ecological injuries being avoided in the first instance or redressed after the fact poses substantial problems for lawmaking institutions attempting to construct a legal regime for environmental protection. These include serious tensions created between environmental protection goals and legal doctrine in areas of law governing behavior that may cause ecological injury. Lawmaking institutions must strive to resolve these tensions, many of which resist easy answers. Because, moreover, the distributional stakes of alternative resolutions are so great, any institutional efforts to fashion environmental protection rules are invariably plagued by competition both between sovereign authorities and between branches of government within any one sovereign, which raises another array of legal issues.

The Article's thesis is that, unlike some lower court judges, the Justices have never fully appreciated environmental law as a distinct area of law. They perceive environmental law instead as merely an incidental factual context, in which environmental protection concerns are at stake, but there is nothing uniquely environmental about the legal issues being raised. The Justices, accordingly, fail to appreciate how the nature of the environmental concerns being addressed can sometimes be relevant to their resolution of those legal issues.

Nor have the Justices (with one distinct exception) embraced either environmental law's ends or the importance of the values it emphasizes. These values should be entitled to substantial weight in the balancing of competing considerations that the Justices invariably undertake in deciding how to vote on a host of legal issues presented to the Court. The Justices' attitudes towards environmental law, moreover, have become increasingly skeptical over time. This result has occurred notwithstanding the tenacity with which the public, in general, and the legislative and executive branches, in particular, have during this same time period maintained and expanded the nation's commitment to environmental protection through an increasingly comprehensive and demanding set of legal rules. ${ }^{3}$

There are, moreover, significant costs and risks associated with the Justices' apparent indifference and occasional hostility towards environmental

3. To be sure, it would seem odd to characterize either the executive branch during the first term of the Reagan Administration or the House of Representatives during the 104th Congress, or even since, as favoring that federal environmental protection laws be "maintained and expanded," but the characterization would be accurate nonetheless. Notwithstanding substantial misgivings, they responded to public opinion by abandoning plans to limit or repeal existing laws and ultimately ended up enacting even stronger environmental protection laws in their place. See Richard J. Lazarus, Faimess in Environmental Law, 27 ENVTL. L. 705, 707-10 (1997). 
law. Environmental protection goals are frustrated, resulting in substantial losses in environmental quality and public health and welfare. Also lost are important lessons that environmental law teaches about existing legal doctrine and lawmaking processes and institutions that are necessary for their proper evolution.

As a result, the Court sometimes fails to modify a particular area of law in its application to an environmental context. Other times, the cost is the Court's failure to appreciate that an entire area of law warrants rethinking because of the broader repercussions of the problems in existing law that environmental issues serve to highlight. In the former circumstance, the change in legal rule is relatively confined (to the environmental setting), but in the latter the legal change applies more broadly.

Exploring this thesis, the Article is divided into three parts. The first undertakes a detailed analysis of votes of the Justices in each of the Supreme Court's environmental cases during the past three decades (1969-1999) that can be fairly said to establish the current temporal boundaries of the modern era of environmental law. The analysis and related findings are both qualitative and quantitative, although the latter's effort to "score" numerically each of the Justices on their promotion of environmental protection is riddled with caveats to guard against its potential foolish misuse.

The second part of the Article strives both to explain these findings and to comment upon their significance. The former undertaking includes discussion of what the findings suggest about the nature of environmental law. Included in this explanation is how environmental law relates to other areas of law with which it inevitably and repeatedly intersects. The latter commentary extends to what may be the most important conclusion emerging from the overall analysis of the Court's environmental case law, which is that the Justices themselves are misapprehending the relationship of environmental law to these other intersecting areas of law. What is increasingly absent from the Court's analysis is an adequate appreciation of the distinctively environmental dimension of environmental law. Too few, if any, members of the Court seem to grasp how that environmental dimension is relevant to the law's evolution and, therefore, should be relevant to the Court's own rulings.

The third and final part of the Article considers how to restore what is environmental about environmental law. This requires, in the first instance, discussion of what is environmental about environmental law. This necessarily includes identifying both the central features of environmental law that make it somehow distinctive and the significance of those features for both legal doctrine and lawmaking institutions and processes. Finally, the Article discusses how the Justices, including future Justices, might be better persuaded of this broader view of environmental law and the importance of its ends. 


\section{THREE DECADES OF ENVIRONMENTAL LAW IN THE SUPREME COURT: A SCORECARD OF WHO WROTE, WHOSE VIEWS PREVAILED, AND HOW, IF AT ALL, DID THE ENVIRONMENT INFLUENCE THE VOTES OF INDIVIDUAL JUSTICES}

Commencing with the Supreme Court's October Term 1969, the Court has decided over 240 environmental law cases. ${ }^{4}$ The sample is sufficiently large to support a host of intriguing statistical inquiries. This Article, however, focuses on only three: (1) which Justices wrote the most decisions for the Court during the past thirty years; (2) which Justices have been in the majority the most frequently; and (3) which Justices have tended to vote for outcomes that are more rather than less protective of the environment, and which Justices have tended to do the converse (that is, less rather than more).

\section{A. The Justices Who Wrote the Most Environmental Decisions for the Court}

Speculation regarding the identity of the Justice who has written the most environmental opinions for the Court during the past thirty years would likely begin with Chief Justice Rehnquist. The Chief Justice has served on the Court the longest of anyone presently there and his tenure virtually spans the relevant time period. He joined the Court as a Justice in 1971, just as the modern era of environmental law was commencing. He has, accordingly, participated in 213 of the 243 environmental cases decided by the Court during the past three decades, which is significantly more than any other Justice. ${ }^{5}$

But in fact, neither is it the Chief Justice leading the pack nor is it even a close question as to who has written the most environmental opinions for

4. A full listing of the cases is included infra in Appendix A to this Article. Whether a case is considered "environmental" for the hroader purposes of this threshold inquiry turns on whether environmental protection or natural resources matters are at stake. The legal issue before the Court need not independently have an environmental character to it. The stakes themselves are sufficient to invoke the label. One reason why the data set for this Article is so large is that I have included all the "original action" cases decided by the Court that involve disputes over natural resources (a few also involve pollution control). These cases range from quite significant disputes between states over water allocation, see, e.g., Texas v. New Mexico, 462 U.S. 554 (1983); Arizona v. California, 460 U.S. 605 (1983); Colorado v. New Mexico, 459 U.S. 176 (1982), to more rarified boundary disputes between states and between states and the United States, see, e.g., Louisiana v. Mississippi, 466 U.S. 96 (1984). Even when such seemingly mundane boundary disputes are at issue, however, they may mask natural resource disputes of enormous environmental significance. See, e.g., United States v. Alaska, 521 U.S. 1 (1997).

5. His closest competitors are Justices Blackmun, White, and Stevens, who heard 201, 196, and 186 cases respectively. See infra Appendix B. 
the Court. Nineteen Justices have served on the Court during the relevant time period, ${ }^{6}$ and Justice White, who left the Court in 1993, is the leading opinion writer for the Court by a large margin.

Justice White has written thirty-six environmental opinions. The next closest is Justice O'Connor, with twenty-two opinions for the Court. What is revealing about Justice White's identity as the most prolific opinion writer for the Court in environmental cases is that, as far as can be discerned, White harbored no particular interest in environmental law. His opinions are dispassionate, dry, and formalistic, with little effort to elaborate any particular philosophical vision.

In this respect, moreover, Justice White's environmental law opinions do not differ from his opinions for the Court generally. Perhaps not unlike the Justice himself, a recent biography is matter of fact and dispassionate in its assessment of White's opinion writing as evidencing little "elaboration of a philosophical vision" and "never aspir[ing] beyond plain, workmanlike prose." "He wrote to get the job done, no more." "Being non-ideological and non-doctrinaire [was] clearly very important to White, ${ }^{10}$ and he displayed "disdain for ideological enthusiasms."1

Justice White's opinions, consistent with his pattern, certainly do not exhibit any environmental ethic. Nor do they express an anti-environmental ethic. In fact, White's opinions fail to suggest that the environmental dimension of the cases played any independent role in the Court's decision or reasoning. ${ }^{12}$

Justice White's controlling philosophy (or lack thereof) is exemplified by his votes in three cases during the 1986 October Term. The Supreme Court that term handed down the so-called Takings Trilogy, three cases raising Fifth Amendment regulatory takings challenges to environmental

6. The Justices are Harlan, Black, Douglas, Stewart, Brennan, White, Marshall, Blackmun, Powell, Stevens, O'Connor, Scalia, Kennedy, Souter, Thomas, Ginsburg, and Breyer, and there have been two Chief Justices, Burger and Rehnquist.

7. DeNNis J. HutChINSON, THE MAN Who ONCE WAS WhizZER WhITE 451 (1998) (quoting Kate Stith, Byron R. White, Last of the New Deal Liberals, 103 YALE L.J. 19, 19 (1993)).

8. Id. at 454 .

9. Id. at 454 (quoting Frank Allen, former co-clerk to Justice White).

10. Id. at 457 (quoting David Frederick, former clerk to Justice White).

11. Id. at 446 (quoting Vincent Blasi, Columbia Law School professor).

12. Justice White's general neutrality on the environmental protection dimension of cases is also consistent with his general voting pattern in those cases, at least as reflected in a score of 36.3 out of a possible 100, with the latter representing a "perfect" score favoring environmental protection in all votes cast. See infra text accompanying note 114 . To that same effect it is noteworthy that Hutchinson's recent biography of the Justice includes virtually no mention of any environmental cases in discussing White's opinions for the Court, even though White was the Court's leading opinion writer in environmental law cases. See generally HUTCHINSON, supra note 7. 
restrictions. ${ }^{13}$ In its first ruling, Keystone Bituminous Coal Ass'n v. DeBenedictis ${ }^{14}$ the Court by a slim five-to-four vote rejected a takings challenge brought against a Pennsylvania law that sharply limited surface coal mining because of the associated risks to the environment and public safety. ${ }^{15}$ What made the ruling especially remarkable was the Court's narrow reading of its seminal regulatory takings precedent, Pennsylvania Coal Co. v. Mahon, ${ }^{16}$ written by Justice Holmes ${ }^{17}$ and from which Justice Brandeis famously dissented. ${ }^{18}$

In its second relevant decision that same term, the Court in First English Evangelical Lutheran Church v. County of Los Angeles ${ }^{19}$ rejected the arguments of the United States and of state and local governments nationwide by ruling that the Fifth Amendment's Just Compensation Clause mandated a remedy in money damages (presumably measured by just compensation) for regulatory takings, including temporary takings. ${ }^{20}$ But it was the Court's third decision, Nollan v. California Coastal Commission ${ }^{21}$ that, juxtaposed with Keystone Bituminous Coal, presented a true jurisprudential paradox. It was not simply because the Court held unconstitutional a state restriction on development that conditioned the development on the landowner's providing the public with access to his privately owned beach immediately in front of his home. ${ }^{22}$ It was because, in Nollan, the Court both resurrected and substantially reinvigorated the very Pennsylvania Coal regulatory takings opinion by Holmes that the Court had a few weeks earlier seemed, remarkably, to bury.

Only one Justice was in the majority in all three cases: Justice White. White, however, offered no hint as to how he reconciled the three votes. He did not author any of the three opinions. Nor did he choose to elaborate on his views in any separately filed concurring opinions. He simply voted. In the absence of any discernible explanation, express or implied, it seems fair to state that Justice White was not basing his vote in these three cases on any overarching theory of the relationship of private property to environmental protection in the Fifth Amendment regulatory takings context.

Even more broadly, based on his opinions for the Court, it is equally fair to say that the leading opinion writer for the Court in environmental

13. See Frank Michelman, Takings, 1987, 88 COLUM. L. REV. 1600, 1600-01 (1988).

14. 480 U.S. 470 (1987).

15. See id. at 474 .

16. 260 U.S. 393 (1922).

17. See id. at 412 .

18. See id. at 416 (Brandeis, J., dissenting).

19. 482 U.S. 304 (1987).

20. See id. at 321 .

21. 483 U.S. 825 (1987).

22. See id. at 831-37. 
cases during the past three decades was not someone possessing any distinct vision of the role of law in environmental protection. His opinions for the Court do not reflect any deliberation regarding the special demands that environmental protection may place on law and lawmaking institutions. White expressed no thoughts concerning the possible impact of scientific uncertainty or irreversible impacts on standards of judicial review. Nor, similarly, do his opinions display any discernible effort to discern and consider how the interests of future generations in environmental protection may warrant consideration in the law's evolution.

The official papers of Justice Thurgood Marshall, which are publicly available through the Library of Congress, provide a surprisingly illuminating example of Justice White's thinking and its impact on both his vote and the Court's rulings. In Chemical Manufacturers Ass'n v. Natural Resources Defense Council, Inc., ${ }^{23}$ the issue before the Court was the validity of the EPA's construction of section 301 of the Clean Water Act to allow for the agency to grant so-called fundamentally different factor variances for discharges of toxic pollutants. ${ }^{24}$ Justice White wrote an opinion for the Court's slim five-Justice majority that upheld the EPA's construction of the Clean Water Act, thereby rejecting the Natural Resource Defense Council's (NRDC's) contention that the statutory language precluded allowing such a variance for toxic discharges.

The Marshall papers disclose that at the Court's conference Justice White, in his own words, initially "waffl[ed]" on whether he would write in favor or in opposition to the EPA's toxic variance policy. Somewhat paradoxically, the Chief Justice assigned the opinion of the Court to him regardless of his ultimate vote, apparently because whichever way White voted would be the fifth vote and therefore constitute the majority view. Justice White ultimately decided to vote in favor of the EPA and to write the opinion to that effect. ${ }^{25}$

In internal correspondence to Justice Marshall, who wrote the dissent for himself and three other Justices, White revealed his rationale. ${ }^{26} \mathrm{He}$ stated that he saw "little or no difference in principle between us, and administrative law will not be measurably advanced or set back however this case

23. 470 U.S. $116(1985)$.

24. See id. at 118 n.2 (citing EPA requirements under the Clean Water Act $\$ 307,33$ U.S.C. $\$ 1317$ ). Congress has since amended section 301 to include a fundamentally different factor variance expressly applicable to toxic pollutant discharges. See Clean Water Act $\S 301,33$ U.S.C. $\$ 1311(\mathrm{n})(1994)$.

25. See Letter from Justice Byron R. White to Chief Justice Warren E. Burger 1 (Nov. 13, 1984) (on file with the Manuscript Division, Library of Congress).

26. See Letter from Justice Byron R. White to Justice Thurgood Marshall 1 (Feb. 13, 1985) (on file with the Manuscript Division, Library of Congress). 
is decided. ${ }^{27}$ In effect, because no overarching principles of administrative law were at stake, White did not see the case, whichever way it was decided, as being of significant import. The case presented only a narrow, fact-bound issue whether there was sufficient basis in the administrative record to support this one administrative rule. The environmental protection aspects of the case played no apparent role of independent significance.

In contrast, Justice Marshall's dissenting opinion emphasized the relevancy of the environmental protection context to the issues of statutory construction before the Court. The dissent discussed how factors such as scientific uncertainty, possible "irreversible or catastrophic results,",28 and the presence of "thresholds" in environmental problems should influence the Court's legal analysis. ${ }^{29}$ The dissent also explained how "when Congress has attached great importance to certain environmental goals, [the Court] $\mathrm{ha}[\mathrm{s}]$ disallowed exceptions even in the absence of an explicit statutory ban." ${ }^{30}$ Marshall's dissent, in short, responded to the environmental context within which the administrative law issue arose and discerned how that context should affect the issue's resolution. White's opinion for the Court in Chemical Manufacturers Ass'n, like his environmental and natural resource opinions in general, evinced no such contextual awareness and drew no such readily available connections.

\section{B. The Justices Who Were Most Often in the Majority in Environmental Cases}

Another revealing factual inquiry concerns the frequency with which individual Justices were in the majority in environmental cases during the past thirty years. ${ }^{31}$ In evaluating the frequency, however, one must place the results in context, because the Justices actually are unanimous in their views far more often than is realized in all cases, not just in environmental cases. During the Court's four most recent October Terms (1995-98), for instance, the Court reached a unanimous result in $38.7,37.2,43$, and 29.6 percent of all cases. ${ }^{32}$ The overall percentages for unanimous opinions

27. Id.

28. Chemical Mfrs. Ass'n, 470 U.S. at 159 (Marshall, J., dissenting).

29. See id. at 159 n.19.

30. Id. at 160 .

31. The results of this analysis are compiled infra in Appendix B.

32. See The Supreme Court, 1998 Term-The Statistics, 113 HARV. L. REV. 400, 404 (1999); The Supreme Court, 1997 Term-Leading Cases, 112 HARV. L. REV. 122, 370 (1998); The Supreme Court, 1996 Term-Leading Cases, 111 HARV. L. REV. 197, 433 (1997); The Supreme Court, 1995 Term-Leading Cases, 110 HARV. L. REv. 135, 369 (1996). Historically, however, the proportion of Supreme Court opinions with a dissenting opinion has been much higher since about 1940 . Between 1800 and 1940, with rare exceptions, no more than 20 percent of the opin- 
are similarly high for environmental and natural resources cases during the past three decades, although lower than these generally applicable percentages for the four most recent terms. Out of the 243 environmental cases decided on the merits since October Term 1969, the Court decided eighty-six without any dissent, or 35.4 percent of the cases. Fifty-seven ( 23.5 percent) of these cases were decided by a unanimous vote.

Consequently, the percentage differences between the Justices in their joining the majority in environmental cases are relatively small. The lowest percentage out of the nineteen Justices whose votes were surveyed is 64.5 percent and belongs to Justice Douglas. ${ }^{33}$ The highest score belongs to Justice Kennedy, who voted with the majority over 96 percent of the time. ${ }^{34}$

Not surprisingly, Justice White's percentage for being in the majority is very high; he voted with the majority 86.9 percent of the time. There is, of course, at least one neutral explanation for why he wrote so many opinions for the Court. He had more opportunities because of his lengthy tenure on the Court. But opportunities and opinions do not necessarily go hand-inhand. Chief Justice Burger, for instance, had an even higher percentage for being in the majority and wrote far fewer opinions. The Chief Justice was in the majority in over 90 percent of the relevant cases. Yet, he wrote only eight opinions for the Court.

The explanation for this phenomenon is likely different from that for White. Burger had a reputation for changing or otherwise manipulating his vote in order to retain the power to assign the opinion. ${ }^{35}$ The Chief Justice's prerogative was to vote first, but Burger frequently either voted last or changed his initial "tentative" vote after the others had voted in order to be in the majority. ${ }^{36}$ Some view his doing so as deriving from a desire to be ideologically manipulative. If in the majority, the Chief Justice would, as the most senior Justice, have the power of assigning the opinion and could therefore

ions generally included a dissent, and the percentage was often lower than 10 percent. See LEE EPSTEIN \& JACK KNIGHT, THE CHOICES JUSTICES MAKE 24 fig.2-1(1998).

33. Justice Douglas's percentages, however, provide an especially tenuous basis for drawing conclusions, because the sample of cases was so small. Notwithstanding Justice Douglas's notoriety on environmental matters, he voted in only 18 environmental cases before the Court. If, moreover, one included in his vote tallies two cases in which he did not side clearly with either the dissent or the majority and counted those as dissents, Justice Douglas's percentage for being in the majority would fall even lower.

34. The broader significance of Justice Kennedy's role in environmental cases before the Court is discussed infra text accompanying notes $42-48$.

35. See EPSTEIN \& KNIGHT, supra note 32, at 125-35; EDWARD LAZARUS, ClOSED CHAMBERS 350 (1998) ("The other Justices had fumed over past instances where the Chief had usurped the assignment power ...."); BOB WOODWARD \& SCOTT ARMSTRONG, THE BRETHREN 64-69 (1979).

36. See WOODWARD \& ARMSTRONG, supra note 35, at 66-67. 
simply assign the case either to himself or to someone likely to draft an opinion in a way he found most sympathetic. ${ }^{37}$

When Chief Justice Burger authored the opinion in one of the most celebrated environmental cases during the past thirty years, the snail darter case, Tennessee Valley Authority v. Hill, ${ }^{38}$ there was contemporaneous speculation that he had done just that: changed his vote so that he could assign the opinion to himself and then write an opinion that questioned rather than embraced the very result the Court reached, in order to promote congressional revisions of the Endangered Species Act. ${ }^{39}$ The Chief Justice's opinion for the Court certainly includes some rhetoric seemingly skeptical of the policy implications of its own ruling. ${ }^{40}$ Perhaps further buttressing the veracity of that initial speculation, the official papers of Justice Marshall have since revealed that the Chief Justice initially voted with the dissenters. ${ }^{41}$

The most telling fact about the tendency of Justices to vote in the majority in environmental cases, however, does not relate to either Chief Justice Burger or Justice White. The Justice with the most astounding record for being in the majority is Justice Kennedy. Kennedy has participated in fifty-seven environmental cases to date. Yet, other than in an original action concerning an interstate water compact, ${ }^{42}$ the Justice has dissented

37. See id. at 64-65. Another possibility is that Chief Justice Burger was adhering to a traditional parliamentary format in which the chair of a proceeding votes last. This possibility was suggested to me by a former clerk to the Chief Justice, who disputed the thesis that Burger was deliberately manipulative. Adhering to the traditional practice of many clerks not to speak on the record about their clerkship experiences, he preferred to speak without attribution.

38. 437 U.S. 153 (1978).

39. See Endangered Species Act of 1973, 16 U.S.C. $\$ \$ 1531-1544$ (1994).

40. See, e.g., Tennessee Valley Authority, 437 U.S. at 159 ("Until recently the finding of a new species of animal life would hardly generate a cause célèbre."); id. at 172 ("It may seem curious to some that the survival of a relatively small number of three-inch fish among all the countless millions of species extant would require the permanent halting of a virtually completed dam for which Congress has expended more than $\$ 100$ million."); id. at 194 ("Our individual appraisal of the wisdom or unwisdom of a particular course consciously selected by the Congress is to be put aside in the process of interpreting a statute.").

41. See Robert V. Percival, Environmental Law in the Supreme Court: Highlights from the Marshall Papers, [1993 News] 23 Envtl. L. Rep. (Envtl. L. Inst.) 10606, 10610-11 (Oct. 1993). My own view is that the power of opinion assignment likely prompted Chief Justice Burger to vote last or to change his vote to be in the majority, but not necessarily based on some ideological motivation. It may well have been simply an effort to maximize his bureaucratic authority within the Court. The more often he was in the majority, the more often he could disburse the wealth of the Court: the assigning of opinions in the more interesting cases. See WOODWARD \& ARMSTRONG, supra note 35, at 64-65. Or more neutrally stated, the more often the Chief Justice possessed the assignment power, the more able he would be to ensure rough equity amongst the Justices in his opinion assignments. Such rough equity is significantly harder to accomplish if the identity of the Justice assigning the opinion frequently changes.

42. See Oklahoma v. New Mexico, 501 U.S. 221, 242 (1991) (Kennedy, J., joining in a concurring and dissenting opinion by Rehnquist, C.J.). 
only once: Pennsylvania ข. Union Gas $\mathrm{Co}^{43}$ The Court, moreover, has since overruled its Eleventh Amendment decision in Union Gas." So, in effect, Justice Kennedy's record is almost 100 percent (putting aside a few somewhat qualified concurring or partially concurring opinions). ${ }^{45}$

But how many opinions for the Court has Justice Kennedy written? Based solely on the ratios for other Justices comparing number of cases in the majority to Court opinions, one might expect as many as ten but certainly no fewer than six. But, in fact, until the Court's most recent term, Kennedy had written only two opinions for the Court. ${ }^{46}$ This past term, he added two more. ${ }^{47}$ Kennedy supplied, moreover, the deciding fifth vote in three out of those four cases.

This is a striking result. The most significant vote has had little to no direct expression in the Court's opinion writing. Justice Kennedy is the key to the majority in environmental protection and natural resources law cases today. Yet he almost never writes an opinion for the Court on these issues.

The upshot is the exacerbation of the Court's longstanding lack of environmental voice. Justice White, who wrote most of the opinions, did not provide it. Justice Kennedy, who now appears to reflect the controlling philosophy for the Court in these cases, has similarly not yet expressed an overarching view of the environmental law field. He has instead mostly just joined opinions that, because they are the product of shifting majority coalitions, lack any coherent or consistent theme. ${ }^{48}$

\section{Scoring the Justices on Environmental Protection}

The last categorical inquiry concerns the voting patterns of individual Justices based on the relationship of their votes to environmental protection and natural resource conservation objectives. For this purpose, the Article undertakes two different kinds of inquiries. The first is more qualitative and impressionistic. The second is more quantitative. The former reviews the votes of the Justices in each of the environmental cases decided during the

43. 491 U.S. 1, 29 (1989) (Kennedy, J., joining in a dissenting opinion by Scalia, J.).

44. See Seminole Tribe v. Florida, 517 U.S. 44, 63-73 (1996).

45. During the October 1991 Term, Justice Kennedy filed a concurring opinion in Lujan $v$. Defenders of Wildlife, 504 U.S. 555, 579 (1992) (Kennedy, J., concurring), which joined Justice Scalia's majority opinion with some qualifications, and a concurring opinion in Lucas v. South Carolina Coastal Council, 505 U.S. 1003, 1032 (1992) (Kennedy, J. concurring), which joined only in the judgment.

46. See Idaho v. Coeur d'Alene Tribe, 521 U.S. 261, 263 (1997); C\&A Carbone, Inc. v. Town of Clarkstown, 511 U.S. 383, 385 (1994).

47. See Amoco Prod. Co. v. Southern Ute Indian Tribe, 119 S. Ct. 1719, 1721 (1999); City of Monterey v. Del Monte Dunes at Monterey, Ltd., 119 S. Ct. 1624, 1631 (1999).

48. A few isolated opinions of Justice Kennedy, however, suggest the possibility of his developing his own distinct vision of environmental law. See infra text accompanying notes 177-181. 
past three decades to discern whether their votes exhibited a clear and discernible pattern of either promoting or not promoting environmental protection. The second inquiry examines each case and labels one possible outcome as the environmentally favored outcome and the other as the environmentally disfavored result, for the ultimate purpose of assigning each Justice a "score" based on the extent to which their votes favored more rather than less environmental protection.

Three mutually compatible hypotheses emerge from these qualitative and quantitative reviews of the votes of the individual Justices in environmental cases. The first is that most of the votes of most of the Justices suggest that the environmental protection dimension of the case was not an influential factor one way or the other. The second hypothesis is that, notwithstanding this initial finding, the votes of a very few Justices over the past three decades do reveal enough of a disproportionate tendency to vote one way rather than another in environmental cases to suggest that the environmental context was, for them, a substantial factor influencing their votes. For some, this led them to vote for the more environmentally protective outcome. And for some others, the contrary is true.

The third hypothesis is that environmental protection concerns are receiving an increasingly disinterested or unappreciative audience before the Court. Historically, those responding to the environmental concerns included Justices seemingly sympathetic to the kinds of restrictions being imposed by environmental law, including the kind of evolutionary pressure those concerns place on existing legal doctrine and lawmaking institutions and processes. Increasingly, however, those on the Court responding to the environmental context seem to be dominated by Justices who are affirmatively unsympathetic to such environmental concerns and who seem more interested in resisting and reversing those evolutionary pressures on the law. Each of these three hypotheses is discussed in more detail below.

1. For Most of the Justices the Environmental Protection Dimension of a Case Before the Court Does Not lnfluence Their Vote

The strongest evidence supporting the first hypothesis, which is that for most of the Justices in most cases the environmental protection dimension was not a factor affecting their votes, is the paradoxical nature of the voting patterns if assessed exclusively from an environmental protection perspective. The more qualitative review of the voting patterns of a few Justices in selected cases is illustrative.

Chief Justice Rehnquist, for instance, has a reputation in the environmental communiry for being unsympathetic to environmental protection 
concerns. There is some basis for that reputation in many of his votes. Representative examples include his votes in favor of narrowly reading the scope of federal reserved water rights in national forests in United States $v$. New Mexico; ${ }^{49}$ against enhanced procedural rights for environmentalists in Vermont Yankee Nuclear Power Corp. v. NRDC; $;^{50}$ against an interpretation of the Endangered Species Act in Tennessee Valley Authority ${ }^{51}$ that barred the construction of a virtually completed multimillion-dollar dam; ${ }^{52}$ and in favor of a more aggressive application of the Fifth Amendment Takings Clause in a host of cases, including, for example, both Penn Central Transportation Co. v. New York City ${ }^{53}$ and Keystone Bituminous Coal. ${ }^{54}$

But labeling the Chief Justice as somehow "anti-environmental" becomes more problematic and inappropriate if one considers many of his other votes that strongly favor environmentaily protective outcomes. Examples include his votes favoring the government's contention in United States $v$. Fuller ${ }^{55}$ that it need not compensate a fee owner in an eminent domain proceeding for the value of the land attributable to the Taylor Grazing Act permits applicable to adjacent property; upholding criminal convictions under section 13 of the Rivers and Harbors Act in United States v. Pennsylvania Industrial Chemical Corp. ${ }^{56}$ rejecting federal preemption claims in favor of sustaining stricter local noise controls in City of Burbank ข. Lockheed Air Terminal, Inc.; ${ }^{57}$ construing section 118 of the Clean Air Act to require federal installations to comply with state air pollution control requirements in Hancock $v$. Train; ${ }^{58}$ dissenting in Japan Whaling Ass' $n$ v. American Cetacean Society ${ }^{59}$ along with Justices Marshall, Blackmun, and Brennan, contending that the secretaty of commerce was required to "certify" Japan for failing to comply with International Whaling Convention whaling quotas; ${ }^{60}$ and providing the critical fifth pro-environmental vote in California Coastal Commission v. Granite Rock Co., ${ }^{61}$ in favor of imposition of state restrictions on federal mining patentees.

\footnotetext{
49. 438 U.S. $696,718(1978)$.

50. 435 U.S. $519,548(1978)$.

51. 437 U.S. 153 (1978).

52. See id. at 211 (Rehnquist, J., dissenting).

53. 438 U.S. 104, 152-53 (1978) (Rehnquist, J., dissenting).

54. 480 U.S. $470,520-21$ (1987) (Rehnquist, J., dissenting).

55. 409 U.S. $488,488,490-94$ (1973).

56. 411 U.S. 655, 675-76 (1973) (Rehnquist \& Black, JJ., dissenting in part).

57. 411 U.S. 624, 650-54 (1973) (Rehnquist, J., dissenting).

58. 426 U.S. 167,199 (1976) (Rehnquist, J., dissenting).

59. 478 U.S. $221(1986)$.

60. See id. at 241, 246 (Marshall, J., dissenting).

61. 480 U.S. $572,579-94$ (1987).
} 
Indeed, several of Chief Justice Rehnquist's opinions (unlike those of Justice Whit ${ }^{62}$ ) stress the importance of the environmental protection goals as an affirmative reason for upholding the challenged governmental action. The Chief Justice has, for instance, dissented in a series of dormant commerce clause cases, including City of Philadelphia v. New Jersey, ${ }^{63}$ Chemical Waste Management, Inc. v. Hunt, ${ }^{64}$ and Oregon Waste Systems, Inc. v. Department of Environmental Quality, ${ }^{65}$ in favor of the constitutionality of states' discriminating against interstate commerce to protect their environments from solid and hazardous wastes originating in other states. Apart from Justice Douglas, whose environmentalist tendencies were infamous, ${ }^{66}$ Rehnquist's opinions are among the few during the past three decades to emphasize the pressing nature of environmental problems. ${ }^{67} \mathrm{He}$ is certainly the only Justice to suggest any appreciation of the roots of claims of environmental injustice. ${ }^{68}$

Justice Stevens, on the other hand, is generally considered sympathetic to environmental protection concerns, based on several opinions that he has authored and joined. These include his opinion for the Court in Keystone Bituminous Coal, ${ }^{69}$ sustaining a surface mining law challenged as a regulatory taking; ${ }^{70}$ his dissents in both Nollan v. California Coastal Commission ${ }^{71}$ and Lucas v. South Carolina Coastal Council, ${ }^{72}$ opposing regulatory takings challenges to state regulation of development on the coastal zone; and his

62. See supra text accompanying note 12.

63. 437 U.S. 617, 629 (1978) (Rehnquist, J., dissenting).

64. 504 U.S. 334, 349 (1992) (Rehnquist, C.J., dissenting).

65. 511 U.S. 93, 108 (1994) (Rehnquist, C.J., dissenting).

66. See infra note 305 and accompanying text.

67. See, e.g., Chemical Waste Management, Inc., 504 U.S. at 349-50 (Rehnquist, C.J., dissenting) (stating that "States may take actions legitimately directed at the preservation of the State's natural resources," and that "hazardous waste ... presents risks to the public health and environment that a State may legitimately wish to avoid"); City of Philadelphia, 437 U.S. at 629 (Rehnquist, J., dissenting) ("A growing problem in our Nation is the sanitary treatment and disposal of solid waste.").

68. The Chief Justice's dissents in the dormant commerce clause cases suggest awareness that technological advances are leading to the siting of waste treatment facilities based on market dynamics rather than on geographic differences between sites, and the possible unfairness to those communities that the market, left unchecked, will repeatedly choose. See Oregon Waste Sys., Inc., 511 U.S. at 112-16 (Rehnquist, C.J., dissenting) (permitting the fee differential because "[t]he availability of environmentally sound landfill space and the proper disposal of solid waste strike me as justifiable 'safety or health' rationales for the fee," and because "nothing in the Commerce Clause ... compels less densely populated States to serve as the low-cost dumping grounds for their neighbors"); Fort Gratiot Sanitary Landfill, Inc. v. Michigan Dep't of Natural Resources, 504 U.S. 353, 372 (1992) (Rehnquist, C.J., dissenting) (stating that because of technological advances, "siting a modern landfill can now proceed largely independent of the landfill location's particular geological characteristics").

69. Keystone Bituminous Coal Ass'n v. DeBenedictis, 480 U.S. 470, 473 (1987).

70. See id. at 481-502.

71. 483 U.S. 825, 866, 866-67 (1987) (Stevens, J., dissenting).

72. 505 U.S. 1003, 1061, 1075-76 (1992) (Stevens, J., dissenting). 
dissents in Weinberger v. Romero-Barcelo, ${ }^{73}$ arguing for injunctive remedies for environmental violations, ${ }^{74}$ and Secretary of the Interior v. California, ${ }^{75}$ in support of enhanced environmental restrictions on oil and gas leasing on the outer continental shelf. ${ }^{76}$

But, as with Chief Justice Rehnquist, a more complicated image emerges if one considers other Stevens votes, in which he displays no special sympathy towards environmental protection concerns. These include both his dissent in Granite Rock, ${ }^{77}$ in which he would have held preempted state environmental regulation of mining activities on federal land, and Penn Central, in which, joining then-Justice Rehnquist's dissenting opinion, ${ }^{78}$ Stevens would have ruled against the constitutionality under the Fifth Amendment Takings Clause of a state historic landmark designation law's application to Grand Central Terminal, ${ }^{79}$ as well as his dissent in City of Chicago v. Environmental Defense Fund, ${ }^{80}$ in which he would have rejected the Environmental Defense Fund's claim that a federal hazardous waste rule was insufficiently protective of the environment. ${ }^{81}$

Justice Stevens's votes in many environmental cases have not only often been unsympathetic to environmental protection goals but have also frequently been dispositive of the outcome in the case before the Court. Stevens supplied the critical fifth votes in United States v. New Mexico, ${ }^{82}$ in which the Court ruled that a reservation of public lands for national forests did not include the reservation of water rights necessary for aesthetics and wildlife preservation; ${ }^{83}$ Industrial Union Department v. American Petroleum Institute, ${ }^{84}$ in which he also wrote the plurality opinion invalidating the secretary of labor's benzene rule ${ }^{85}$ and Japan Whaling Ass' $n,{ }^{86}$ in which the

73. 456 U.S. 305,322 (1982) (Stevens, J., dissenting).

74. See id. at 322-23.

75. 464 U.S. 312, 344 (1984) (Stevens, J., dissenting).

76. See id. at 344-45.

77. California Coastal Comm'n v. Granite Rock Co., 480 U.S. 572, 606 (1987) (Powell, J., dissenting)

78. See Penn Cent. Transp. Co. v. New York City, 438 U.S. 104, 138 (1978) (Rehnquist, J., dissenting).

79. Strictly speaking, the Court's decision in Penn Central does not neatly fit into the "environmental" category. It is a case concerning historic preservation in an urban setting. I have included the case in the Article's data set, however, simply because the case's regulatory takings analysis has served as one of the leading opinions applicable to similar takings challenges brought against environmental regulations.

80. 511 U.S. 328, 340 (1994) (Stevens, J. dissenting).

81. See id. at 348-49.

82. 438 U.S. 696 (1978).

83. See id. at 718.

84. 448 U.S. 607, 611 (1980).

85. See id. at $652-62$.

86. Japan Whaling Ass'n v. American Cetacean Soc'y, 478 U.S. 221, 223 (1986). 
Court ruled that the secretary of commerce was not required to certify Japan for refusing to abide by the International Whaling Convention whaling quotas. ${ }^{87}$ Finally, during the Court's most recently completed term, Justice Stevens provided the decisive fifth vote in favor of the properry owner's position in City of Monterey v. Del Monte Dunes at Monterey, $L t d{ }^{88}$ that it was entitled under the Seventh Amendment to a jury trial of its regulatory takings claim based on the city's repeated denials of a development permit, and that the jury had properly sustained the takings claim. ${ }^{89}$

A similar pattern emerges with Justice Brennan, who, while generally considered sympathetic to environmental concerns, authored the environmentalist's nightmare of a dissent in San Diego Gas $\mathbb{E}$ Electric Co. v. City of San Diego, ${ }^{90}$ which subsequently became the Court's holding in First English ${ }^{91}$ in favor of a constitutionally compelled remedy of money damages for regulatory takings. ${ }^{92}$ Brennan also provided the fifth vote for upholding the EPA's variance policy for toxic effluent discharges in Chemical Manufacturers Ass'n v. NRDC, ${ }^{93}$ and he dissented in 1986 in Dow Chemical Co. v. United States, ${ }^{94}$ in favor of greater Fourth Amendment limitations on the government's ability to enforce environmental restrictions through airborne surveillance techniques. ${ }^{95}$

Justice O'Connor's and Justice Marshall's voting histories are susceptible to a seemingly similar diagnosis. Despite Justice O'Connor's reputation for generally being less sympathetic to environmental protection concerns, she joined Justice Blackmun's impassioned dissent in Lujan v. Defenders of Wildlife, ${ }^{96}$ in favor of environmental citizen suit standing; ${ }^{97}$ and she dissented both in First English, ${ }^{98}$ in favor of a government's ability to restrict develop-

87. See id. at 231-41.

88. 119 S. Ct. 1624,1630 (1999)

89. The ruling in favor of the property owner in City of Monterey is especially significant because it represents the first occasion that the Court has ever upheld a regulatory takings claim based just on the so-called first prong of the regulatory takings test announced in Agins v. City of Tiburon, 447 U.S. 255, 260 (1980), which considers whether the challenged regulation "substantially advance[s] legitimate state interests." Id.

90. 450 U.S. 621, 636 (1981) (Brennan, J., dissenting).

91. First English Evangelical Lutheran Church v. County of L.A., 482 U.S. 304, 315 (1987).

92. See CHARLES M. HAAR \& JeROLD S. KA YDEN, LANDMARK JUSTICE: THE INFLUENCE OF WILLIAM J. BRENNAN ON AMERICA'S COMMUNITIES 39-43 (1989) (describing Justice Brennan's dissent in San Diego Gas \& Electric Co. ).

93. 470 U.S. 116, 117, 125-34 (1985).

94. 476 U.S. 227, 240 (1986) (Brennan, J., joining a concurring and dissenting opinion by Powell, J.).

95. See id. at 252.

96. 504 U.S. 555, 589 (1992) (O'Connor, J., joining a dissenting opinion by Blackmun, J.).

97. See id. at 594-606.

98. First English Evangelical Lutheran Church v. County of L.A., 482 U.S. 304, 322 (1987)

(O'Connor, J., joining in part a dissenting opinion by Stevens, J.). 
ment in a floodplain, ${ }^{99}$ and in Chemical Manufacturers, ${ }^{100}$ in which she (unlike Justice Brennan) supported the NRDC's more environmentally protective reading of the Clean Water Act. ${ }^{101}$ Justice O'Connor also voted in favor of state environmental protection measures in Granite Rock, ${ }^{102}$ and she authored the opinion for the Court in PUD No. 1 v. Washington Department of Ecology, ${ }^{103}$ which endorsed a broad reading of state environmental authority over federally licensed hydroelectric facilities that environmentalists widely hail. ${ }^{104}$ Justice Marshall who was generally considered more sympathetic to environmental concerns, however, provided the fifth vote against the Clean Air Act criminal prosecution in Adamo Wrecking Co. v. United States; ${ }^{105}$ like Brennan, Marshall dissented in the Dow Chemical case; ${ }^{106}$ and, perhaps most significantly, Marshall authored the Court's opinion in Gwaltney of Smithfield, Ltd. v. Chesapeake Bay Foundation, Inc., ${ }^{107}$ which, to the great dismay of environmentalists, severely limited the reach and effectiveness of citizen suit enforcement under the Clean Water Act. ${ }^{108}$

Based on this broader, qualitative, and ultimately impressionistic review of the voting in environmental cases, there is simply too much cacophony in the votes of individual Justices to support a thesis that environmental protection concerns are generally a primary motivating factor in the Court's decisions and the votes of the Justices. The counterexamples are too many.

2. The Voting Records of a Few Justices Suggest that the Environmental Protection Dimension of a Case Affected Their Resolution of the Legal Issue Before the Court

There are nonetheless some individual tendencies that become discernible upon even closer examination of the Justices' votes in environmental cases. A more quantitative review of the voting patterns suggests

\footnotetext{
99. See id. at 322-23.

100. 470 U.S. 116, 165 (O'Connor, J., dissenting).

101. See id. at 165 .

102. California Coastal Comm'n v. Granite Rock Co., 480 U.S. 572, 579-94 (1987).

103. 511 U.S. 700, 703 (1994). See generally Katherine P. Ransel, The Sleeping Giant Awakens: PUD No. 1 of Jefferson County v. Washington Department of Ecology, 25 ENVTL. L. 255 (1995).

104. See PUD No. 1,511 U.S. at $710-13$.

105. 434 U.S. $275,276(1978)$.

106. See Dow Chem. Co. v. United States, 476 U.S. 227, 240 (1986) (Marshall, J., joining a concurring and dissenting opinion by Powell, J.).

107. 484 U.S. 49, 52 (1987).

108. See William H. RODGERS, JR., ENVIRONMENTAL LAW $\S 4.3$, at 289 (2d ed. 1994) ("The Supreme Court has rolled back citizen suits in a variety of ways. But the most serious setback is the Court's holding in Gwaltney of Smithfield v. Chesapeake Bay Foundation ... [which] combines poor lawyering with unconvincing semantics and bad history.").
} 
that a few individual Justices were more likely to rule in favor of or against an environmentally protective outcome because of that outcome's environmental dimension.

The more quantitative analysis of the voting of the Justices is not based on all 243 cases. It is instead based on their votes in the potentially more telling cases: a subset of approximately 100 cases that more readily lend themselves to "pro" or "anti" environmental protection assignment for scoring purposes. ${ }^{109}$ The objective of this analysis is to construct a scoring system somewhat analogous to that employed by the League of Conservation Voters Test in scoring members of Congress on environmental matters. ${ }^{110}$ Here, however, it is applied to the Justices. A Justice is awarded one point for each pro-environmental protection outcome for which the Justice voted. The final score, referred to hereinafter as an "EP score," is based on the percentage of pro-environmental votes the Justice cast out of those cases within the 100-case sample in which that Justice participated. An EP score of 100 means that a Justice voted for the environmentally protective outcome in all the cases in which he or she participated. A score of zero means that the Justice voted for that environmental outcome in none of the cases.

There is inevitably arbitrariness and sometimes downright foolishness in attempting any such "pro" or "anti" policy assignments to Supreme Court rulings, especially assignments that purport to be binary in nature (i.e., for or against). The problem, of course, is two-fold. First, most cases do not lend themselves to the assignment of one of two opposing labels. There are more typically an array of possible outcomes with their different policy implications less stark than polar opposites. Second, in most instances, it is also undoubtedly true that whether a particular outcome happened to be more or less environmentally protective had little, if any, impact on an individual Justice's decision to vote one way rather than another. That is, the environmental implications were often not the motivating force behind the vote. They were simply an incidental factor that the Justice deemed not relevant to the legal issue before the Court, whether that issue was a question of administrative law and standards of judicial review applicable to administrative agency action, ${ }^{111}$ corporate law relating to parent corporate responsibil-

109. A listing of those 100 cases appears infra in Appendix C. That listing includes both a breakdown of the voting and a designation of either the majority, concurring, or dissenting position as receiving the "EP" score in that case.

110. See League of Conservation Voters, National Environmental Scorecards (visited Jan. 14, 2000) <http://www.lcv.org/scorecards/index.htm>.

111. See, e.g., Chevron U.S.A. 1nc. v. Natural Resources Defense Council, Inc., 467 U.S. $837,842-45$ (1984). 
ity for the actions of subsidiary corporations, ${ }^{112}$ or Tenth Amendment law concerning the limitations that amendment imposes on the federal government's authority to compel certain actions by state governments. ${ }^{113}$

This Article seeks to account for the first concern at least to some extent by relying only upon the subset of approximately 100 cases rather than the full 243-case sample. The second threshold concern-the likelihood that individual Justices were not motivated, in any event, by environmental concerns-properly cautions against gleaning great meaning from small differences in scores in either a relative or an absolute sense. But so long as one confines conclusions to those Justices whose EP scores are at either the very high end or the very low end, some interesting conclusions can fairly be drawn. To that end, this Article deliberately accords no especial meaning to scores between the two extremes, even largely differing scores. Those differences are not deemed to provide a fair basis for positing that the environmental protection dimension of the case played more than an incidental role.

But for those few Justices with scores either very high or very low, it is at least plausible to theorize that the environmental protection dimension influenced their vote one way or the other. A fair case can be made for scores above sixty-six or below thirty-three. Moreover, a strong case can be made that scores above seventy-five or below twenty-five reflect pronounced tendencies in environmental cases.

Beyond that essential interpretive limitation, however, this Article deliberately does not otherwise try to remove cases from the sample based on the possibility, even the potential likelihood, that the environmental context may have had nothing to do with the Justice's decision to vote one way rather than another. This is not done precisely because it is the very phenomenon this Article explores: Whether the trends in the votes of individual Justices suggest that the environmental context of a case influenced their vote in a direction either consistent or inconsistent with environmental protection concerns; or, alternatively, whether the votes of the individual Justices instead create the impression that environmental protection is little more than a factual context for them in their resolution of legal issues, but lacking any independent jurisprudential content related to the environment. One cannot test a hypothesis by gathering data that conclusively presumes its invalidity.

112. See, e.g., United States v. Bestfoods, 524 U.S. 51, 55 (1998).

113. See, e.g., New York v. United States, 505 U.S. 144, 149 (1992); EPA v. Brown, 431 U.S. $99,100(1977)$. 
With these threshold caveats, most of the numerical scores for the nineteen Justices simply confirm what was suggested by the prior, more qualitative analysis, which is that the environmental protection aspect of the case had no discernible impact on the Justice's vote. Justice White, for instance, received a score of thirty-six, which is at the low end. But a thirty-six is still within the broad middle ground that does not suggest any discernible influence one way or the other. ${ }^{14}$

For certain Justices, however, some clear patterns do emerge. For a very few, the scores suggest that they systematically favored a policy outcome that promoted environmental protection. For some others, and there were more in this camp, their scores suggested at least some skepticism, if not some affirmative hostility. Although the identities of some of these Justices are likely obvious to Court watchers, there are nonetheless a few surprises. (The results appear graphically on the following page and are also compiled in Appendix D.)

With regard to those Justices who were the most environmentally protective, however, the high scores are both easy to identify and not especially surprising. The highest score went to Justice Douglas. He scored 100. Justice Douglas may well be the only environmental justice ever on the Court, at least in modern times. ${ }^{115}$ And, notwithstanding his high profile, Justice Douglas was, as a practical matter, barely there for modern environmental

114. It may also be problematic to compare Justices who served at very different times on the Court-for instance, Justice Stewart and Justice Souter-because the nature of the issues and lower court rulings coming before the Court may have changed substantially during their respective years of service on the Court. This could, of course, be the result of changes in the Court itself, which would still be relevant to my inquiry, but it also might occur because of changes in the lower courts, in Congress, or within the executive branch. A more liberal appellate judiciary, for instance, could make the Supreme Court look more conservative to the extent that it was reversing those lower court rulings. Similarly, an executive branch agency seeking to cut back on environmental protection by stretching its authority beyond legitimate bounds would, by forcing those issues on the Supreme Court, make the Court look more environmentally inclined to the extent that the Court rejected the agency's decisions. In short, the Court could, in theory, remain constant while its rulings appeared more or less favorable to the environment because of changes occurring elsewhere in government that systematically affected the issues and rulings presented to the Court. See Molly S. McUsic, Looking Inside Out: Institutional Analysis and the Problem of Takings, 92 Nw. U. L. REV. 591, 611 (1998) ("[T]he issues that come before the Court and are thus available for doctrinal development are a function of the legislation and regulation that capture the fancy of the political majority.").

115. The "modern times" caveat here acknowledges that there were Justices, Justice Oliver Wendell Holmes in particular, who authored opinions at a time when environmental law consisted of little more than the common law and who expressed some environmental ethic. See, e.g., Hudson County Water Co. v. McCarter, 209 U.S. 349 (1908); Georgia v. Tennessee Copper Co., 206 U.S. 230 (1907); see also New Jersey v. New York, 283 U.S. 336, 342 (1931) ("A river is more than an amenity, it is a treasure."). Of course, Justice Holmes's votes were not all favoring environmental protection goals. See, e.g., Pennsylvania Coal Co. v. Mahon, 260 U.S. 393 (1922). 
FP Scores by Justice

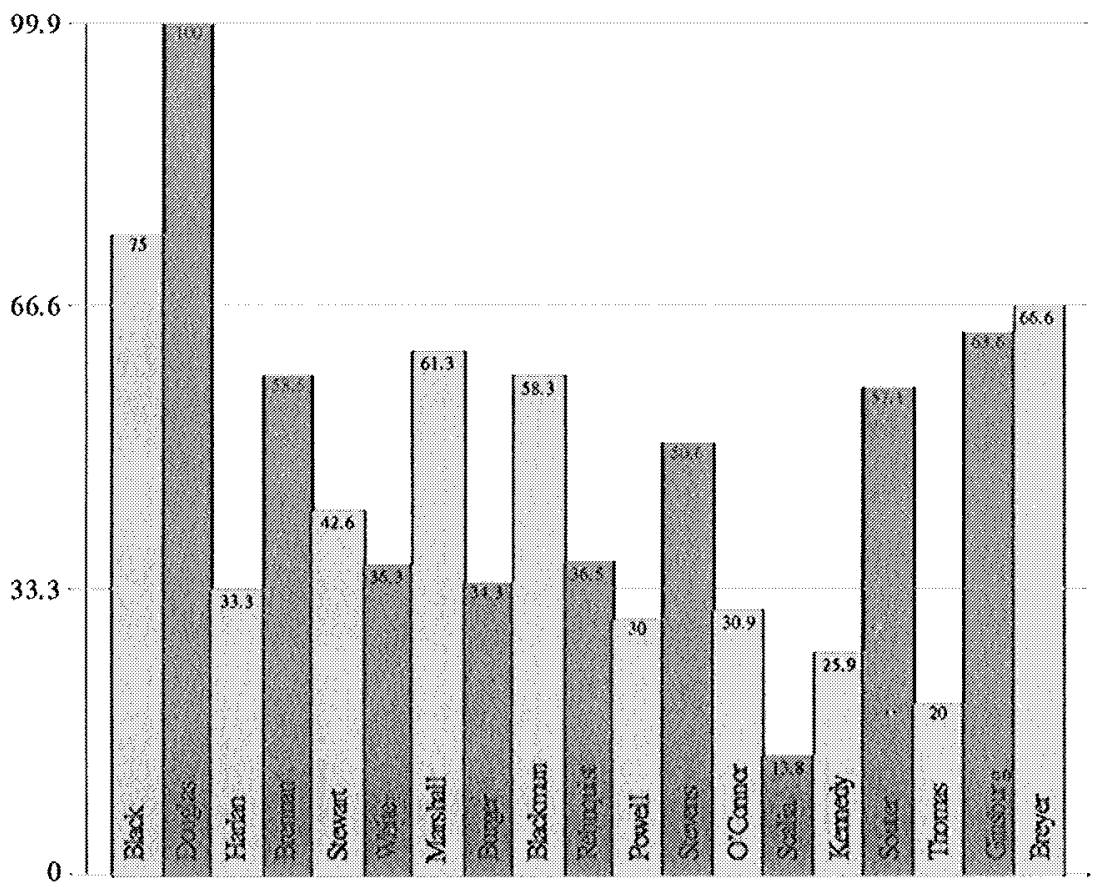

law. Because he resigned from the Court in 1975, he voted in only fifteen of the approximately 100 cases surveyed for the EP score. His persistence in voting nonetheless for the pro-environmental side in each of those cases, no matter what the legal issue before the Court, is quite striking.

The next highest IIP scores are those of Justices Ginsburg, Marshall, Brennan, Blackmun, Stevens, and Souter: ${ }^{16}$ Each of their scores, however, is not only much lower than Justice Douglas's, but also below the score (sixty-six) that I am willing to characterize as even roughly suggesting that environmental concerns served as a motivating factor. Justice Ginsburg's is the highest at sixty-three, but her case sample is still so low (eleven) as to further undermine any hypothesis explaining her relatively pro-environmental record. Bremnan (58.5) and Marshall (61.3) scored just below and just above sixty, respectively, participating in over eighty of the surveyed cases. Justice Stevens scored only fifty (also reflecting participation in over eighty cases).

116. The scores of both Justice Black (75) and Justice Breyer (66.6) are actually both higher, but they are based on too few cases to be telling. Black voted in only four of the cases, and Breyer in only six. 
Perhaps the most promising Justice today is Justice Souter, who scored fiftyseven. ${ }^{117}$

Although few think of Justice Blackmun in relation to environmental law, Blackmun's voice on environmental issues was considerable. As in much of his work as a Justice, ${ }^{118}$ Blackmun transformed himself in the environmental area. In the early years, his strong tendency was to vote in a manner antagonistic to environmental interests, though he did not himself author the majority or dissenting opinions that he joined. He accordingly dissented in Tennessee Valley Authority, ${ }^{119}$ voted with the majority against attorney fees recovery in Alyeska Pipeline Service Co. v. Wilderness Society, ${ }^{120}$ and similarly voted with the majority in the United States v. New Mexico reserved water rights case. ${ }^{121}$ But commencing with the 1985 October Term, Justice Blackmun's votes reflect a very different judicial attitude towards environmental protection concerns.

Considering just the thirty-five cases in which he participated from the October Term 1985 until his retirement, his EP score was seventy-six. In his final fifteen cases, moreover, Blackmun voted on the environmentally protective side fourteen times, for an EP score of 93.5. Justice Blackmun wrote passionately in those cases. His opinions include environmental rhetoric reminiscent of the 1970s. In Lucas, ${ }^{122}$ Justice Blackmun's dissent accuses the majority of "launch[ing] a missile to kill a mouse." ${ }^{\text {"23 }}$ In Lujan v. Defenders of Wildlife, ${ }^{124}$ his dissent emotionally denounces the majority for its "slash-andburn" through the "law of environmental standing."125

Applying my criteria, however, only two Justices cross the barrier at the high end: Justice Douglas, of course, and the transformed Justice Blackmun. None of the others (including Stevens, Brennan, Marshall, and Souter) has a sufficiently high EP score to suggest that the environmental protection dimension of the various cases before the Court was a factor influencing their respective votes.

117. Environmentalists are especially hopeful about Justice Souter based on the tenor of opinions he has authored, see, e.g., Dolan v. City of Tigard, 512 U.S. 374 (1994), opinions he joined as a state supreme court justice, see, e.g., Rowe v. Town of N. Hampton, 553 A.2d 1331 (N.H. 1989), and his apparently strong personal interest in the outdoors, see infra note 311.

118. See Linda Greenhouse, Justice Blackmun, Author of Abortion Right, Dies, N.Y. TIMES, Mar. 5, 1999, at A1.

119. 437 U.S. 153, 195 (1978) (Blackmun, J., joining a dissenting opinion by Powell, J.).

120. 421 U.S. $240,240(1975)$.

121. 438 U.S. $696,696(1978)$.

122. Lucas v. South Carolina Coastal Council, 505 U.S. 1003 (1992).

123. Id. at 1036 (Blackmun, J., dissenting).

124. 504 U.S. 555 (1992).

125. See id. at 606 (Blackmun, J., dissenting). 
The low EP scores are, by contrast, more telling. They identify several Justices with EP scores small enough to suggest some possible skepticism, or perhaps even hostility, towards environmental protection concerns or the kind of legal regime they promote. There are many EP scores below thirty-three, and still many below thirty, and two even below twenty-five. As with the high EP scores, here too there is a hands-down winner, though no score of zero to offset Justice Douglas's score of 100. And, as with Justice Douglas, there are no surprises in terms of identity at the lowest of the low end of the scores.

The lowest score goes to Justice Scalia with a thirteen. That is a strikingly low score. It is a score so low that one can fairly posit that Justice Scalia perceives environmental protection concerns as systematically promoting a set of legal rules antithetical to those he generally favors. His concerns seem related to the ways in which environmental protection concerns may promote governmental authority at the expense of individual autonomy, such as in the exercise of property rights. They also seem related to the ways in which environmental protection promotes an expansive judicial oversight role for the federal judiciaty, federal mandates to state governmental authorities, and a far-reaching interpretation of congressional Commerce Clause authority. ${ }^{126}$

Indeed, the kind of legal regime promoted by environmental law seems to be of sufficient concern that it even prompts Justice Scalia sometimes to abandon what otherwise appear to be his views on core matters involving constitutional and statutory interpretation. Thus, in Lucas, Justice Scalia's opinion for the Court relies upon a very un-Scalia-like notion of a "constitutional culture" to support the Court's ruling in favor of the property owner challenging environmental regulation as a regulatory taking. ${ }^{127}$ In PUD No. 1 ข. Washington Department of Ecology, ${ }^{128}$ Justice Scalia is fairly

126. Environmental law can justly be characterized as classically representative of the New Deal/Great Society constitutional regime that many on the current Court, with Justice Scalia at the ideological helm, seem to be questioning. See generally McUsic, supra note 114, at 618-20; Mark Tushnet, The Supreme Court, 1998 Term-Foreword: The New Constitutional Order and the Chastening of Constitutional Aspiration, 113 HARV. L. REV. 29 (1999). Expansive congressional Commerce Clause authority, diminished states' rights, eroding private property rights, and relaxed citizen suit standing are all features of modern environmental law, and each has been questioned by recent Court decisions.

127. See also Michael J. Gerhardt, A Tale of Two Textualists: A Critical Comparison of Justices Black and Scalia, 74 B.U. L. REV. 25, $61-63$ (1994); Frank 1. Michelman, Property, Federalism, and Jurisprudence: A Comment on Lucas and Judicial Conservatism, 35 WM. \& MARY L. REV. 301, 31128 (1993). Compare Lucas, 505 U.S. at 1028 ("[T]hat the State may subsequently eliminate all economically valuable use is inconsistent with the historical compact recorded in the Takings Clause that has become part of our constitutional culture."), with Planned Parenthood v. Casey, 505 U.S. 833, 980 (1992) (Scalia, J., dissenting) ("[T]he Constitution says absolutely nothing about it ....").

128. 511 U.S. 700 (1994). 
accused by a colleague of abandoning his adherence to the plain meaning of statutory language in order to embrace a less environmentally protective statutory construction of the Clean Water Act. ${ }^{129}$

Perhaps most revealing, however, is the language Scalia uses in his opinions discussing environmental protection concerns. Justice Scalia plainly takes great pride in his writing. Unlike Justice White, ${ }^{130}$ Scalia writes with much passion and flair that strongly reflects his own voice. His treatment of environmental protection concerns is, at the very least, highly skeptical of their efficacy and frequently borders on the disdainful.

Ultimately, however, Justice Scalia's votes and thetoric simply confirm what he has previously written in a nonjudicial setting, where he has taken pains to single out environmental protection laws as especially problematic. In a 1983 law review article then-Judge Scalia wrote before joining the Court, he decried the judiciary's apparent "long love affair with environmental litigation." ${ }^{132}$ And in response to those 1970s judges who embraced the propriety of special solicitude to environmental protection claims, Scalia made it quite explicit that he thought that it would be a "good thing, too" to have policies such as those furthered by federal environmental protection law get "lost and misdirected in the vast hallways of the federal bureaucracy." ${ }^{133}$ According to the Justice, "[ $\left.t\right]$ he ability to lose or misdirect laws can be said to be one of the prime engines of social change. ${ }^{1134}$

129. Justice Scalia is well known for his promotion of "plain meaning" judicial construction of statutory language. See generally ANTONIN SCALIA, A MATTER OF INTERPRETATION: FEDERAL COURTS AND THE LAW (1997). Justice Stevens in PUD No. 1 goes out of his way to chide Justice Scalia (and Justice Thomas) for their dissent in that case because of what he perceives to be a departure from plain meaning to reach a policy objective more favorable to the regulated community. See PUD No. 1, 511 U.S. at 723 (Stevens, J., concurring).

130. See supra text accompanying notes 7-11.

131. See, e.g., Bennett v. Spear, 520 U.S. 154, 176-77 (1997) (stating that the goal of the Endangered Species Act "is to avoid needless economic dislocation produced by agency officials zealously but unintelligently pursuing their environmental objectives"); Lujan v. Defenders of Wildlife, 504 U.S. 555, 566 (1992).

Respondents' other theories are called, alas, the "animal nexus" approach, whereby any. one who has an interest in studying or seeing the endangered animals anywhere on the globe has standing; and the "vocational nexus" approach, under which anyone with a professional interest in such animals can sue. Under these theories, anyone who goes to see Asian elephants in the Bronx Zoo, and anyone who is a keeper of Asian elephants in the Bronx Zoo, bas standing to sue because the Director of the Agency for International Development (AID) did not consult with the Secretary regarding the AID-funded projld. ect in Sri Lanka. This is beyond all reason.

132. Antonin Scalia, The Doctrine of Standing as an Essential Element of the Separation of Powers, 17 SUFFOLK U. L. REV. 881, 884 (1983).

133. Id. at 897 .

134. Id. Justice Scalia is responding to Judge Skelly Wright's famous statement in Calvert Cliffs' Coordinating Committee, Inc. v. United States Atomic Energy Commission, 449 F.2d 1109, 
Although Scalia's EP score is the most striking, he is not the lone Justice with an extremely low score. Not surprisingly, Justice Thomas has the next lowest score (twenty), though this score is less telling because the case sample is relatively low (twenty cases). Justice O'Connor is at 30.9, and both former Chief Justice Burger (34.3) and current Chief Justice Rehnquist (36.5) have scores just above thirty-three.

One Justice with a possibly surprising EP score below thirty-three is Justice Powell, at thirty. Justice Powell's general reputation is as a traditional conservative but with strongly moderating tendencies. ${ }^{135}$ Whatever the accuracy of that characterization applied broadly, it is much less validly applied to Powell's voting patterns in environmental protection cases. In fact, even Justice Powell's already very low EP score is likely inflated because of the large number of environmental cases (nine) in which he recused himself from participating while on the Court. ${ }^{136}$

The basis for those recusals, Justice Powell's legal experience in private practice before joining the Court, also likely explains his apparent deeply held skepticism of the efficacy and fairness of the environmental protection laws of the 1970s. Justice Powell had been a Hunton \& Williams attorney in Richmond, Virginia. While at the law firm, Powell himself represented industry, including the Albermarle Paper Company and its ultimate acquisition, Ethyl Corporation. ${ }^{137}$ These were not incidental clients, but rather were among the first of his major clients that "made Powell an independent force in Hunton, Williams." ${ }^{138}$ Hunton \& Williams was then and remains today one of the country's leading environmental law firms, with a reputation as providing zealous, aggressive representation to industry (especially the electric utility industry) in environmental litigation. For years, the head of that practice was George Freeman, who was at Hunton \& Williams with Powell. Freeman was a longtime close personal friend and someone who played a significant role in promoting Powell for the opening on the Court. ${ }^{139}$

Powell accordingly recused himself in several major environmental cases before the Court. They included cases in which his former clients were

1111 (D.C. Cir. 1971) (declaring that it was the court's "duty, in short, ... to see that important legislative purposes, heralded in the halls of Congress, are not lost or misdirected in the vast hallways of the federal bureaucracy").

135. See, e.g., Gerald Gunther, A Tribute to Justice Lewis F. Powell, Jr., 101 HARV. L. REV. 409, 409 (1987).

136. See infra notes 140-157 and accompanying text.

137. See JOHN C. JEFFrIES, JR., JUSTICE LEWIS F. POWELL, JR. 125, 189-93 (1994). Because of Powell's status at the firm, it was named Hunton, Williams, Gay, Moore \& Powell in 1954. See id. at 130 .

138. See id. at 126.

139. See id. at 230-31; George Clemon Freeman, Jr., A Tribute to Justice Lewis F. Powell, Jr., 101 HARV. L. REV. 404, 408-09 (1987). 
parties $^{140}$ and, early on, cases in which Hunton $\&$ Williams represented an amicus before the Court. ${ }^{141}$ Powell strived to be known for being especially scrupulous on recusals and took great personal umbrage at any accusations that he had failed to recuse himself when he should have done so. ${ }^{142}$ The upshot was that Powell sat out of many major environmental cases, including Vermont Yankee Nuclear Power Corp. v. NRDC, ${ }^{143}$ Baltimore Gas \& Electric Co. v. NRDC, ${ }^{144}$ E. I. duPont de Nemours \& Co. v. Train, ${ }^{145}$ EPA v. National Crushed Stone Ass' $n,{ }^{146}$ United States थ. Students Challenging Regulatory Agency Procedures (SCRAP) ${ }^{147}$ and Aberdeen \& Rockfish R.R. Co. v. Students Challenging Regulatory Agency Procedures (SCRAP), ${ }^{148}$ Train v. NRDC, ${ }^{149}$ and Alyeska Pipeline Serv. Co. v. Wilderness Soc'y ${ }^{150}$

The single most remarkable recusal, though, occurred in Fri v. Sierra Club. ${ }^{151}$ Before the Court in Fri was the Sierra Club's contention (upheld by the lower courts) that Congress intended in the Clean Air Act to require the EPA to establish a program that prevented "significant deterioration" of air quality in those parts of the country that met the stringent air quality standards the EPA had promulgated pursuant to the act. As a strict matter of statutory interpretation, Sierra Club's argument was fairly weak. Hunton \& Williams filed an amicus brief in the Court in support of the EPA's position that no such program was statutorily required. ${ }^{152}$ Presumably as a direct result, however, Powell recused himself from the case and the Court ended up affirming the court of appeals ruling in favor of the Sierra Club, by an equally divided four-to-four vote. ${ }^{153}$ The prevention-of-significant-deterioration

140. When Hunton \& Williams served as counsel for a party, it was usually George Freeman who argued for industry, and Justice Powell routinely recused himself. See, e.g., Baltimore Gas \& Elec. Co. v. Natural Resources Defense Council, lnc., 462 U.S. 87, 108 (1983); EPA v. National Crushed Stone Ass'n, 449 U.S. 64, 85 (1980); Vermont Yankee Nuclear Power Corp. v. Natural Resources Defense Council, lnc., 435 U.S. 519, 558 (1978); E.l. duPont de Nemours \& Co. v. Train, 430 U.S. 112, 139 (1977).

141. See, e.g., Train v. Natural Resources Defense Council, Inc., 421 U.S. 60, 99 (1975); Fri v. Sierra Club, 412 U.S. 541, 542 (1973).

142. See JEFFRIES, supra note 137, at 274-81.

143. See 435 U.S. at 558.

144. See 462 U.S. at 108.

145. See 430 U.S. at 139.

146. See 449 U.S. 64, 85 (1980).

147. See 412 U.S. 669,699 (1973).

148. See 422 U.S. $289,328(1975)$.

149. See 421 U.S. 60,99 (1975).

150. See 421 U.S. $240,271(1975)$

151. 412 U.S. 541,542 (1973).

152. See id. at 541 n. ${ }^{*}$ (listing Henry V. Nickel for the Edison Electric Instirute as amicus curiae).

153. The official papers of Justice Thurgood Marshall reveal that the Sierra Club was originally poised to lose by a five-to-three vote in an opinion for the Court authored by Justice Stewart, until Justice Marshall switched his vote to the Sierra Club, thereby prompting both the tie vote and the 
program, which Congress subsequently codified into law, ${ }^{154}$ has since become a major aspect of federal environmental law. ${ }^{155}$ Perhaps for that reason, ${ }^{156}$ not long after the Fri affirmance, Justice Powell stopped recusing himself from cases in which Hunton \& Williams's involvement was limited to their appearance as amicus curiae in the case. ${ }^{157}$

But when not recused, Powell served up judicial thetoric that sometimes surpasses even Scalia's in its skepticism of federal environmental protection laws. In Union Electric Co. v. EPA, ${ }^{158}$ he referred to the Clean Air Act as "Draconian" and went so far as to suggest the propriety of its congressional revision..$^{159}$ In Tennessee Valley Authority, ${ }^{160}$ he decried the Court's interpretation of the Endangered Species Act as an "absurd result" that "casts a long shadow over the operation of even the most important projects, serving vital needs of society and national defense." ${ }^{161}$ As with the Clean Air Act, Powell expressly invited Congress to overrule, in effect, the majority ruling from which he was dissenting. ${ }^{162}$

Court's affirmation by an equally divided Court. See Letter from Justice Thurgood Marshall to Justice Stewart 1 (June 5, 1973) (on file with the Manuscript Division, Library of Congress).

154. See Clean Air Act, 42 U.S.C. \$\$ 7470-7479 (1994).

155. See Craig N. Oren, Prevention of Significant Deterioration: Control-Compelling Versus SiteShifting, 74 1OWA L. REV. 1, 2-7 (1988).

156. One can fairly speculate that Hunton \& Williams and their industry clients were extremely displeased that their amicus filing prompted Justice Powell's recusal and, hence, their self-inflicted loss on such a significant issue. 1 possess no knowledge as to whether Powell was ever aware of any such possible displeasure or subsequently changed his recusal policy as a direct result.

157. See Train v. Colorado Pub. Interest Research Group, Inc., 426 U.S. 1, 2 (1976).

158. 427 U.S. 246 (1976).

159. See id. at 272 (Powell, J., concurting).

The result apparently required by this legislation ... could sacrifice the well-being of a large metropolitan area through the imposition of inflexible demands that may be technologically impossible to meet and indeed may no longer even be necessary to the attainment of the goal of clean air.

I believe that Congress, if fully aware of this Draconian possibility, would strike a different balance.

Id. (Powell, J., concurting).

160. 437 U.S. 153 (1978).

161. See id, at 195-96 (Powell, J., dissenting).

162. See id. at 210 (Powell, J., dissenting).

I have little doubt that Congress will amend the Endangered Species Act to prevent the grave consequences made possible by today's decision. Few, if any, Members of that body will wish to defend an interpretation of the Act that requires the waste of at least $\$ 53$ million, and denies the people of the Tennessee Valley area the benefits of the reservoir that Congress intended to confer. There will be little sentiment to leave this dam standing before an empty reservoir, serving no purpose other than a conversation piece for incredulous tourists.

Id. (Powell, J., dissenting) (citation and footnote omitted). Justice Powell's opinion for the majority in International Paper Co. v. Ouellette, 479 U.S. 481 (1987), is likewise notable for its aggressiveness in ensuring that regulated industry is not subject to competing state environmental regulators, by 
One can, however, contrast Justice Powell's skepticism towards stringent environmental protection laws with a far more sympathetic approach he displayed towards more traditional natural resources conservation laws, which fell outside of those areas within the core concerns of his apparent experiences with corporate clients in private practice. Justice Powell authored a strongly pro-environmental dissent in United States v. New Mexico, ${ }^{163}$ denouncing what he characterized as the majority's view of forests as "still, silent, lifeless places." ${ }^{164}$ Sounding more like Aldo Leopold ${ }^{165}$ than like a former industry counsel, Powell urged the Court both to consider that "the forests consist of the birds, animals, and fish-the wildlife-that inhabit them, as well as the trees, flowers, shrubs, and grasses" and to accept the "modern view of the forest as an interdependent, dynamic community of plants and animals."166

Although to very different effect, Powell seemingly spoke in United States v. New Mexico from personal experience. But unlike in the other cases, which he approached as former industry counsel, here it was Powell the life-long hunter of small game who was speaking. ${ }^{167}$ And, like many hunters, he apparently harbored some special appreciation of wildlife and the essential ecological needs of their habitats such as national forests, which are managed for multiple purposes, one of which is hunting. ${ }^{168}$

Perhaps similar personal experiences explain Powell's otherwise surprising vote in Penn Central. ${ }^{169}$ Powell joined Justice Brennan's majority

extending the Clean Water Act's preemptive reach to even choice of law rules. See id. at 499; id. at 500 (Brennan, J., concurring).

163. 438 U.S. 696 (1978).

164. See id. at 719 (Powell, J., dissenting) ("I do not agree, however, that the forests which Congress intended to 'improve and protect' are the still, silent, lifeless places envisioned by the Court.").

165. See generally Aldo Leopold, A SAND COUNTY ALMANAC AND SKETCHES HERE AND THERE (1949).

166. See New Mexico, 438 U.S. at 719, 723 n.4.

167. See JEFFRIES, supra note 137, at 24-25, 205, 215.

168. Many hunters are closely associated with conservationist interests because of their appreciation of the outdoors, including forests and their wildlife. Aldo Leopold, no doubt one of the nation's most famous environmentalists, was himself a hunter. See Richard L. Knight, The Role of Private and Public Lands in the Development of Aldo Leopold's Land Ethic, 19 J. LAND RESOURCES \& ENVTL. L. 9, 13 (1999); Eric T. Freyfogle, On the Trail of the Land Ethic, 1992 U. lLL. L. REV. 913, 914 (reviewing ROUND RIVER: FROM THE JOURNALS OF ALDO LEOPOLD (Luna B. Leopold ed., 1991), ALDO LEOPOLD'S WILDERNESS (David E. Brown \& Neil B. Carmony eds., 1990), and THE RIVER OF THE MOTHER OF GOD AND OTHER ESSAYS (Susan L. Flader \& J. Baird Callicott eds., 1991)); see also R. Shep Melnick, Risky Business: Government and the Environment After Earth Day, in TAKING STOCK: AMERICAN GOVERNMENT IN THE TWENTIETH CENTURY 156, 161 (Morton Keller \& R. Shep Melnick eds., 1999) ("[E]nvironmentalism has become a 'big tent' that covers a variety of divergent interests. For example, members of the 'hook and bullet set' hope to kill the very wildlife that 'bird and bunny' groups are trying to protect." (citation omitted)). The Federal Land Policy \& Management Act of 1976, 43 U.S.C. \$§ 1701-1784 (1994), expressly contemplates hunting within national forests. See id. \& 1732(b).

169. See Penn Cent. Transp. Co. v. New York Ciry, 438 U.S. 104, 106 (1978). 
opinion for the Court upholding New York City's historic landmark designation law and rejecting a regulatory takings challenge. ${ }^{170}$ One of Justice Powell's first major clients at Hunton \& Williams was Colonial Williamsburg, and in that capacity he represented that city in defending its historic preservation rules. ${ }^{171}$ Powell, however, displayed no such deference to governmental land use planning challenged as a regulatory taking when the object of restrictions was the kind of surface mining of coal prevalent in his home state of Virginia. He joined the dissenters in Keystone Bituminous $\mathrm{Coal}^{172}$ in which he favored striking down as an unconstitutional taking a state law restricting surface mining of coal because of its adverse economic impact on the owner of the coal estate. ${ }^{173}$ And, while joining the Court's unanimous rejection of a facial takings challenge to surface mining restrictions in Hodel v. Virginia Surface Mining \& Reclamation Ass' $n,{ }^{174}$ he also wrote separately to express his concern that "[t]he Act could affect seriously the owners and lessees of the land and coal in the seven westernmost counties of Virginia" and that, for this reason, future as-applied challenges might well be meritorious. ${ }^{175}$

Finally, Justice Kennedy's EP score is especially noteworthy precisely because he appears to be the Court's current bellwether Justice in environmental cases. ${ }^{176}$ His score, 25.9 is the third lowest out of nineteen Justices over the past thirty years. For those primarily concerned about environmental law, it must be unsettling to learn that 25.9 represents the Court's current point of equilibrium.

The statistics here, however, may well mask significant pro-environmental protection potential. Although Justice Kennedy's writing in the area remains sparse, ${ }^{177}$ he filed concurring opinions in three cases in which he expressed views that create at least the theoretical possibility of his breaking away from Justice Scalia's approach. In Lucas, Justice Kennedy expressed a view

170. See id. at 138.

171. See JEFFRIES, supra note 137, at 128-29. But even in Penn Central, the oral argument transcript in the case shows Powell's focus on the relevance of "economic viability" in deciding the constitutionality of the challenged police power restriction, which is a notion he then elevated from an incidental footnote in Penn Central to one part of a two-part takings test in Agins. See Agins v. City of Tiburon, 447 U.S. 255, 260 (1980); Official Oral Argument Transcript at 41-44, Penn Cent. Transp. Co. v. New York City, 438 U.S. 104 (1978) (argued Apr. 17, 1978). The "economic viability" prong, moreover, subsequently gave birth to Justice Scalia's per se takings test in Lucas v. South Carolina Coastal Council, 505 U.S. 1003, 1014-19 (1992).

172. Keystone Bituminous Coal Ass'n v. DeBenedictis, 480 U.S. 470 (1987).

173. See id. at 506, 520-21 (Rehnquist, C.J., dissenting).

174. 452 U.S. 264, 266 (1981).

175. See id. at 305, 307 (Powell, J., concurring).

176. See supra text accompanying notes $42-48$.

177. See supra text accompanying notes $46-47$. 
of environmental regulation, private property, and the Fifth Amendment far more open to the need for strict controls on the development of fragile ecosystems than Justice Scalia's majority opinion for the Court. ${ }^{178}$ In Lujan v. Defenders of Wildlife, Kennedy's concurring opinion took issue with Scalia's view of citizen suits by contending that Congress retained the authority, notwithstanding Article III, to extend standing to plaintiffs whose injuries were less concrete and dependent on more attenuated chains of causation than present under common law approaches. ${ }^{179}$ Finally, during the October Term 1997, in the nonenvironmental case of Eastern Enterprises v. Apfel, ${ }^{180}$ Justice Kennedy rejected Scalia's plurality opinion for the Court, which relied on an expansive view of regulatory takings doctrine, in favor of a substantive due process approach more favored by environmentalists and government regulators. ${ }^{181}$

178. Justice Kennedy rejected the majority's core holding that background principles of the common law provide an exclusive basis for excusing a police power measure that deprives a land owner of all economically viable use of the property. He singled out "fragile land system[s]" as potentially justifying heightened governmental regulation. See Lucas v. South Carolina Coastal Council, 505 U.S. 1003, 1032-36 (1992) (Kennedy, J., concurring); Richard J. Lazarus, Counting Votes and Discounting Holdings in the Supreme Court's Takings Cases, 38 WM. \& MARY L. REV. $1099,1131-40$ (1997).

179. Justice Kennedy's separate opinion in Lujan expressly acknowledged that

[a]s Government programs and policies become more complex and far reaching, we must be sensitive to the articulation of new rights of action that do not have clear analogs in our common-law tradition.... In my view, Congress has the power to define injuries and articulate chains of causation that will give rise to a case or controversy where none existed before ....

Lujan v. Defenders of Wildlife, 504 U.S. 555, 580 (1992) (Kennedy, J., concurring).

180. 524 U.S. $498(1998)$.

181. See id. at 539-50 (Kennedy, J., concurring). Justice Kennedy's most recent majority opinion for the Court in City of Monterey v. Del Monte Dunes at Monterey, Ltd., 119 S. Ct. 1624 (1999), although affirming the juty verdict in favor of the developer's Fifth Amendment regulatory takings challenge, is also helpful to government regulators in several respects. The majority rejected the Ninth Circuit's application of the "rough proportionality" analysis set forth by the Court in Dolan v. City of Tigard, 512 U.S. 374, 391 (1994), and Nollan v. California Coastal Commission, 483 U.S. 825,834 (1987), as inapposite outside the context of a challenge to a land use exaction. See City of Monterey, $119 \mathrm{~S}$. Ct. at 1635. The majority opinion also took pains to stress the narrowness of its ruling sustaining the jury instructions in City of Monterey and upholding the propriety of a Seventh Amendment right to a jury trial in a regulatory takings case. See id. at $1644-45$; id. at 1631 ("The controlling question is whether, given the city's apparent concession that the instructions were a correct statement of the law, the matter was properly submitted to the jury." (empbasis added)); id. at 1636 ("Given the posture of the case before us, we decline the suggestions of amici to revisit these precedents." (emphasis added)); id. at 1637 ("ln short, the question submitted to the jury on this issue was confined to whether, in light of all the history and the context of the case, the city's particular decision to deny Del Monte Dunes' final development proposal was reasonably related to the city's proffered justifications." (emphasis added)); id. ("[T]he Court of Appeals did not adopt a rule of takings law allowing wholesale interference ... with ... routine regulatory decisions." (emphasis added)); id. at 1644 ("In this case, the narrow question submitted to the jury was whether, when viewed in light of the context and protracted history of the development application process, the city's decision to reject a particular development plan bore a rea- 


\section{The Individual Voting Records of the Justices in Environmental Cases Suggest an Overall Trend Towards Environmental Concerns' Being Less Favored by the Court}

A third finding suggested by the individual EP scores is that the Court as a whole is steadily becoming less responsive to environmental protection. Indeed, the overall shift in the fate of environmental protection before the Court during the past three decades is dramatic.

One striking comparison is to consider the EP scores of the Justices on the Court in 1975 to those on the Court today. For the purposes of this comparison, the EP scores used are those of the Justices for their entire career (as of today) rather than the date selected. In 1975, there were no Justices with an EP score of twenty or lower, only one score of thirty-three or lower, and one Justice with a score over sixty-six. By 1999, the number of Justices with an EP score of twenty or lower has increased from zero to two, and the number of EP scores of thirty-three or lower has increased from one to four. At the same time, the number of Justices with EP scores over sixty-six has fallen from one to zero.

Another slightly more finely tuned comparison is to contrast the EP scores of the Justices in each of the three decades, but based on their votes within those respective decades. ${ }^{182}$ This second comparison reveals the same trend, albeit a bit more dampened than the first. The single largest lowering of EP scores occurs between the 1970s and the 1980s. The 1990s

sonable relationship to its proffered justifications. ... Under these circumstances, we hold that it was proper to submit this narrow, factbound question to the jury." (emphasis added) (citation omitted)).

182. For the purposes of this compilation, the EP score of each Justice is based solely on his or her votes within a particular decade. For instance, because Chief Justice Rehnquist served on the Court during all three decades, separate EP scores were calculated based on his votes in each of the relevant time periods. For some of the Justices, their EP scores shifted substantially ftom one decade to the next. Here again, the Chief Justice is illustrative. For the Courr Terms commencing in the 1970s, 1980s, and 1990s, Rehnquist had EP scores of 38.2, 26.8, and 42.8, respectively. Such shifts may be telling to the extent that they reflect either the changing nature of the issues and rulings before the Court or the Justices' views on those issues. Yet they may also be misleading if too quickly read as indicative of the latter. The nature of the issues before the Court as well as the precise rulings under review may just as well be a reflection of changing circumstances external to the Court, such as the relative ideologies dominant in state courts and lower federal courts, as well as in executive branch agencies, state legislatures, and Congress. See supra note 114. Chief Justice Rehnquist's considerably higher score in the 1990s, for instance, largely resulted from his defense of aggressive action by states during that time period to limit the import of solid and hazardous waste into their borders. See supra text accompanying notes 63-68. Finally, the table in the text above deliberately omits the EP score of any Justice who voted in fewer than ten cases during the relevant decade. Thus, neither the EP scores of Justices Black and Harlan, who voted in only four and three cases respectively during the 1970s, nor those of Marshall and Breyer, who voted in only one and six cases respectively during the 1990s, is reflected in the table. The case sample for each was simply too small (especially for Marshall with only one case). 
maintain the decrease but do not match the level of its acceleration that occurs in the 1980s.

\section{By Decade - The Environmental Protection Scores of the Justices}

\begin{tabular}{|c|c|c|c|c|}
\hline Decade/EP Scores & $\geq 80$ & $\geq 66$ & $\leq 33$ & $\leq 20$ \\
\hline $\begin{array}{c}1970-79 \text { October } \\
\text { Terms }\end{array}$ & 1 & 3 & 1 & 0 \\
\hline $\begin{array}{c}1980-89 \text { October } \\
\text { Terms }\end{array}$ & 0 & 0 & 5 & 1 \\
\hline $\begin{array}{c}1990-98 \text { October } \\
\text { Terms }\end{array}$ & 1 & 1 & 3 & 2 \\
\hline
\end{tabular}

At the high end, the number of Justices with an EP score of sixty-six or more decreases from three during the 1970 s to zero in the 1980 s, and to just one in the 1990s. At the low end, the number of Justices with a score of thirty-three or lower goes from one in the 1970s down to five in the 1980s, and further decreases to three in the 1990s, while those with a score of twenty or below goes from zero to one to two during those three decades.

No doubt each of these two comparisons contains significant flaws. But precise quantification is not necessaty if the sole purpose of the inquiry is to ascertain whether there are any clear overall trends rather than to make fine distinctions. The downward trends in the EP scores of the Justices during the past three decades easily display that level of clarity. ${ }^{183}$

\section{THE JUSTICES' APATHY AND POSSIBLE ANTIPATHY TOWARDS ENVIRONMENTAL PROTECTION: REFLECTIONS ON THE NATURE OF ENVIRONMENTAL LAW}

The overall trends should be troubling for those looking to the Supreme Court for an affirmative interest in promoting environmental protection.

183. At least in theory, however, statistics about trends in the votes of individual Justices do not inexorably establish similar trends in the decisions of the Court. For instance, 40 environmentally favorable votes could reflect five unanimous rulings or nine five-four rulings. For that same reason, 27 environmentally favorable votes might only mean three Court rulings in favor of the environment, while 20 favorable votes could be four favorable rulings. Absent such unanticipated discrepancies between votes and Court rulings, it seems fair to draw inferences about the latter from trends in the former. The more significant limitation upon such temporally based statistical comparisons is the very real possibility that the trends revealed may reflect differences in the issues presented to the Court rather than differences in the Court itself. See supra note 114. 
Environmental protection concerns implicated by a case appear, at best, to play no favored role in shaping the outcome, which is a sharp departure from what many judges in the 1970s conceived of as the proper judicial function in environmental law. ${ }^{184}$ But nor does the outcome seem wholly neutral or indifferent to the presence of those concerns.

Instead, environmental protection concerns seem increasingly over the past three decades to be serving a disfavored role in influencing the Court's outcome. The preferred outcome is one that places less rather than more weight on the need to promote environmental protection. The Court's decisions and the attitudes of the individual Justices reflect increasing skepticism of the efficacy of environmental protection goals and the various laws that seek their promotion. ${ }^{185}$

Even more fundamentally, however, the Court's rulings and the opinions and votes of the Justices suggest the relative absence of any notion that environmental law is a distinct area of law, as opposed to just a collection of legal issues incidentally arising in a factual setting in which environmental protection concerns are what is at stake. The Court's opinions lack any distinct environmental voice. Missing is any emphasis on the nature, character, and normative weightiness of environmental protection concerns and their import for judicial construction of relevant legal rules-how, in other words, the kinds of problems environmental law seeks to address may warrant special consideration in the Court's decisions.

The Court's decisions in Tennessee Valley Authority, ${ }^{186}$ City of Chicago v. Environmental Defense Fund, ${ }^{187}$ and Babbitt v. Sweet Home Chapter of Communities for a Great Oregon ${ }^{188}$ all represent significant, albeit rare, victories for environmental concerns in the Supreme Court. In none of those rulings, however, do those concerns play an explicit positive role, if any, in the Court's analysis. ${ }^{189}$

184. See Harold Leventhal, Environmental Decisionmaking and the Role of the Courts, $122 \mathrm{U}$. PA. L. REV. 509, 509-10 (1974); James L. Oakes, Substantive Judicial Review in Environmental Law, [1977] 7 Envtl. L. Rep. (Envtl. L. Inst.) 50,029, 50,030 (Jan.-Dec. 1977); see also Robert Glicksman \& Christopher H. Schroeder, EPA and the Courts: Twenty Years of Law and Politics, LAW \& CONTEMP. PROBS., Autumn 1991, at 249, 261-64.

185. See J. William Futrell, The Ungreening of the Court, ENVTL. F., Jan.-Feb. 1992, at 12, 16 ("The current Court's silence on the importance of ecological protection ... stands in sharp contrast with Supreme Court opinions of the 1970s, which featured forthright declarations in support of the national environmental goals enunciated by Congress.").

186. 437 U.S. $153(1978)$.

187. 511 U.S. 328 (1994).

188. 515 U.S. 687 (1995).

189. The singling out of these three cases is not intended to suggest that they are the only significant environmental victories during the past three decades. There are most certainly others. See, e.g., PUD No. 1 v. Washington Dept. of Ecology, 511 U.S. 700, 723 (1994) (upholding state authority under the Clean Water Act to impose instream flow requirements on federally 
Chief Justice Burger wrote the majority opinion in Tennessee Valley Authority (the snail darter case). ${ }^{190}$ While the Court upheld the environmental position favoring protection of the snail darter, the Chief Justice's opinion seems somewhat skeptical of the very result that it upholds, suggesting that the statutory language has compelled the Court to endorse such a result, notwithstanding what the Court might believe to be "common sense and the public weal."191 Justice Scalia's opinion for the Court in City of Chicago v. Environmental Defense Fund ${ }^{192}$ contains no such harsh rhetoric, but neither does he acknowledge the possible relevancy of the environmental context and then discuss why the Court should avoid endorsing agency constructions of statutes, such as environmental protection laws, that create broad exceptions in the absence of strong evidence of congressional intent that supports the agency's view. ${ }^{193}$ Finally, even Justice Stevens, writing for the Court in Sweet Home, never relates the environmental context to the Court's rationale. The majority's rationale is devoid of any suggestion that its environmental context-e.g., the irreversibility of species extinction or the teachings of conservation biology-was even relevant to the legal analysis.

Imagine, however, if Justice Douglas were on the Court and writing any of the Court's opinions in those three cases. The Court's rhetoric regarding environmental protection and its legal relevance would have been far different. Recall his genuine passion dissenting in Sierra Club v. Morton in favor of expansive notions of legal standing:

Those who hike the Appalachian Trail into Sunfish Pond, New Jersey, and camp or sleep there, or run the Allagash in Maine, or climb the Guadalupes in West Texas, or who canoe and portage the Quetico Superior in Minnesota, certainly should have standing to defend those natural wonders before courts or agencies, though they live 3,000 miles away. Those who merely are caught up in environmental news or propaganda and flock to defend these waters or areas may be treated differently. That is why these environmental issues should be tendered by the inanimate object itself. Then there will be assurances that all of the forms of life which it represents will stand before the court-the pileated woodpecker as well as the coyote and bear, the lemmings as well as the trout in the streams. Those inarticulate

licensed hydroelectric facilities); United States v. Riverside Bayview Homes, Inc., 474 U.S. 121, 126-29 (1985) (upholding an expansive construction of the jurisdictional scope of the Clean Water Act). The three cases discussed in the text are merely illustrative.

190. See 437 U.S. at 156.

191. Id. at 195; see id. at 194 ("Our individual appraisal of the wisdom or unwisdom of a particular course consciously selected by the Congress is to be put aside in the process of interpreting a stature.").

192. 511 U.S. 328.

193. Cf. Chemical Mfrs. Ass'n v. Natural Resources Defense Council, Inc., 470 U.S. 116, 135 (Marshall, J., dissenting). 
members of the ecological group cannot speak. But those people who have so frequented the place as to know its values and wonders will be able to speak for the entire ecological community. ${ }^{194}$

Or consider Justice Black's emotional dissent in Named Individual Members of the San Antonio Conservation Society v. Texas Highway Department: ${ }^{195}$

The cars will spew forth air and noise pollution contaminating those acres not buried under concrete. Mothers will grow anxious and desert the park lest their children be crushed beneath the massive wheels of interstate trucks. [Environmental] legislation has come about in response to aroused citizens who have awakened to the importance of a decent environment for our Nation's well-being and our very survival. ${ }^{196}$

Such emotion has meaning when it comes from the Court. It sends an influential message to the lower courts and to the public at large. Rigorous, sound legal reasoning need not be devoid of passion or the power of moral suasion to be legitimate or to be effective.

Today, however, the only passionate rhetorical flourishes evident in environmental cases are those penned by Justice Scalia. And they do not trumpet the importance of environmental protection; they question it. ${ }^{197}$ Indeed, apart from those flourishes that strive to disparage or question the efficacy of environmental law, the environment itself seems to have been excised from environmental law.

For most of the Court most of the time environmental law raises no special issues or concerns worthy of distinct treatment as a substantive area

194. Sierra Club v. Morton, 405 U.S. 727, 751-52 (1972) (Douglas, J., dissenting) (footnote omitted).

195. 400 U.S. $968(1970)$.

196. Id. at 969-71.

197. See, e.g., Babbitt v. Sweet Home Chapter of Communities for a Great Oregon, 515 U.S. 687, 714 (1995) (Scalia, J., dissenting) ("The Court's holding that the hunting and killing prohibition incidentally preserves habitat on private lands imposes unfairness to the point of financial ruin - not just upon the rich, but upon the simplest farmer who finds his land conscripted to national zoological use."); id. at 734 n.5 (Scalia, J., dissenting).

For surely the only harm to the individual animal from impairment of that "essential function" is not the failure of issue (which harms only the issue), but the psychic harm of perceiving that it will leave this world with no issue (assuming, of course, that the animal in question, perhaps an endangered species of slug, is capable of such painful sentiments). Id.; see also Lucas v. South Carolina Coastal Council, 505 U.S. 1003, 1025 n.12 (1992) ("Since such a justification can be formulated in practically every case, this amounts to a test of whether the legislature has a stupid staff. We think the Takings Clause requires courts to do more than insist upon artful harm-preventing characterizations."); Lujan v. Defenders of Wildlife, 504 U.S. 555, 566 (1992) ('Respondents' other theories are called, alas, the 'animal nexus' approach, whereby anyone who has an interest in studying or seeing the endangered animals anywhere on the globe has standing; and the 'vocational nexus' approach, under which anyone with a professional interest in such animals can sue."); id. at 567 n.3 ("We decline to join Justice Stevens in this Linnaean leap."). 
of law. Environmental protection is merely an incidental context for resolution of a legal question: of administrative law in Cherron U.S.A. Inc. v. NRDC ${ }^{198}$ and City of Chicago v. Environmental Defense Fund; ${ }^{199}$ First Amendment law in Metromedia, Inc. v. City of San Diego; ${ }^{200}$ Fourth Amendment law in Dow Chemical Co. v. United States ${ }^{201}$ and United States v. Ward ${ }^{202}$ criminal law in United States $v$. International Minerals $\mathbb{E}$ Chemical Corp. ${ }^{203}$ corporation law in United States v. Bestfoods; ${ }^{204}$ and bankruptcy law in Ohio v. Kovacs. ${ }^{205}$

Remarkably illustrative is Justice White's decision, previously described, ${ }^{206}$ to side with the EPA in Chemical Manufacturers Ass' $n,{ }^{207}$ and to uphold the validity of variances for technology-based standards otherwise applicable to discharges of toxic effluent. ${ }^{208}$ White stressed in his note to Marshall that resolution of the case did not make much difference to administrative law one way or the other. ${ }^{209}$

To a certain extent, Justice White's intuition is no doubt correct. Environmental law does not exist in a vacuum. Environmental issues do arise in contexts that implicate other, very important crosscutting areas of law, such as administrative law, corporate law, Tenth Amendment law, Fifth Amendment law, and criminal law. The Court, moreover, must strive in specific cases, including environmental law cases, for consistency in the Court's treatment of those broader issues. At least as a general matter, the Court should not assume that certain basic questions of administrative law, corporate law, criminal law, or other comparable areas of law have one answer in the environmental context and a different answer in another. Indeed, the Court might fairly presume just the opposite: There is one consistent answer applicable to all contexts within which these crosscutting issues arise.

But the Court's intuition in general (and Justice White's in the Chemical Manufacturers Ass'n case, in particular) still falls short. Environmental protection may nonetheless legitimately inform the Court's consideration of crosscutting issues, whether arising within the context of administrative law or any other, and they may sometimes justify striking a new and different balance in their resolution. Environmental protection concerns need not

$\begin{array}{ll}\text { 198. } & 467 \text { U.S. } 837(1984) . \\ 199 . & 511 \text { U.S. } 328(1994) . \\ 200 . & 453 \text { U.S. } 490(1981) . \\ 201 . & 476 \text { U.S. } 227(1986) . \\ 202 . & 448 \text { U.S. } 242(1980) . \\ 203 . & 402 \text { U.S. } 558(1971) . \\ 204 . & 524 \text { U.S. } 51(1998) . \\ 205 . & 469 \text { U.S. } 274 \text { (1985). } \\ 206 . & \text { See supra text accompanying note } 25 . \\ 207 . & 470 \text { U.S. } 116(1985) . \\ 208 . & \text { See id. at } 134 . \\ 209 . & \text { See supra note } 27 \text { and accompanying text. }\end{array}$


always be a dispositive factor to be legitimately so in some instances, and otherwise to be at least a relevant, weighty factor.

The nation's commitment to enhanced environmental protection has served in many lower courts, as it has in the executive and legislative branches, a very positive and appropriate role in evolving many broadly applicable areas of law relevant to the fashioning of legal rules for environmental protection. Administrative law has evolved. So too has tort law, corporate law, bankruptcy law, and criminal law. Indeed, one could fairly posit that hardly any area of law has been untouched by environmental law's emergence during the past thirty years. Environmental law is not, therefore, simply an isolated series of formal legislative enactments and administrative regulations. Those enactments and regulations are just the most formal expressions of a field of law that is far more sweeping in its impact on the legal landscape.

The explanation for environmental law's simultaneously wide and deep reach lies in the way that legal rules reflect balances struck between competing concerns. When the public starts to place greater value on one concern, such as environmental protection, the public's doing so may warrant law reforms of differing orders of magnitude. Sometimes it may warrant a restriking of balances underlying a host of legal rules in a variety of areas. This would occur, for instance, when the environmental dimension of a case illuminates a general doctrinal failing. An entire area of law is, accordingly, rethought.

On other occasions, however, it may be only the legal doctrine's application in the environmental context that requires more careful, and different, consideration. This could occur when the pre-existing doctrinal solution has reflected a balancing of competing values. The balance struck may differ in light of the special weight the environmental context suggests should be given to particular ecological values.

Somewhat ironically in light of Justice White's deliberations in Chemical Manufacturers Ass' $n,{ }^{210}$ one of the best-documented examples of law reform at environmental law's instigation has been the reformation of administrative law that occurred during the 1970s. Change occurred quite often at the instigation of environmental law. But the resulting administrative law framework was not confined in its application to environmental law per se. ${ }^{211}$

210. See supra text accompanying notes 23-27.

211. Environmental issues helped to trigger widely ranging innovations in administrative law such as the "hard look" doctrine, hybrid rule making, expansive opportunities for public participation in the administrative process, and liberalized standing rules for challenges to administrative agency decisions. See Leventhal, supra note 184, at 514; Richard B. Stewart, The Reformation of American Administrative Law, 88 HARV. L. REV. 1667, 1715-16 (1975); see also FREDERICK R. ANDERSON ET AL., ENVIRONMENTAL PROTECTION: LAW AND POLICY 83 (2d ed. 1990) (discussing the substantial alteration of administrative law in response to environmental litigation 
Justice Marshall's dissent in Chemical Manufacturers Ass' $n^{212}$ illustrates the proper use of environmental concerns in legal analysis of an issue of administrative law. It also underscores what was missing from the majority's analysis in that case. Unlike the majority, the dissent apprehends the relevancy for statutory interpretation of the possibility of "small errors" leading to "irreversible or catastrophic results"- a typical feature in environmental problems. ${ }^{213}$ The dissent likewise expressly acknowledges the relevancy for the judicial interpretive function of the fact that because "[e]nvironmental problems often present thresholds," "the cost of a relatively small mistake is very high.,"114

Not surprisingly, however, it is Justice Douglas who was most apt to apprehend how environmental protection concerns can warrant thinking differently about crosscutting legal issues. His dissents from the Court's rulings in two 1973 cases, Salyer Land Co. v. Tulare Lake Basin Water Storage District ${ }^{215}$ and Associated Enterprises v. Toltec Watershed Improvement District, ${ }^{216}$ are illustrative. The Court ruled in those cases that equal protection was not violated by a state statute that excluded tenants and permitted only landowners to vote for candidates for the water storage district and weighed their votes according to the value of the land each owned. ${ }^{217}$ To many, these would appear to be fairly rarified cases, bearing at most only a tangential relationship to environmental law. But that is also precisely why the cases illustrate so well how a fuller appreciation of the environmental dimension of a case may affect the Court's resolution of a legal dispute seemingly unrelated to environmental law.

Justice Douglas understood the environmental connection. He perceived the issues differently from the majority in each case precisely because he understood the role that water played in the lives and ecosystem of the affected tenants:

It is also inconceivable that a body with the power to destroy a river by damming it and so deprive a watershed of one of its most salient environmental assets does not have 'sufficient impact' on the inter-

during the 1970s); Richard J. Lazarus, Meeting the Demands of Integration in the Evolution of Environmental Law: Reforming Environmental Criminal Law, 83 GEO. L.J. 2407, 2415-16 (1995).

212. 470 U.S. at 134 (Marshall, J., dissenting).

213. See id. at 159 (Marshall, J., dissenting).

214. Id. at $159 \mathrm{n} .19$ (Marshall, J., dissenting) ("Environmental problems often present thresholds. For example, if the level of biochemical oxygen demand (BOD) in a river exceeds a certain level, fish life will become impossible. A slightly lower BOD level, however, would prevent this result. Thus, the cost of a relatively small mistake is very high." (citing BRUCE A. ACKERMAN ET AL., THE UNCERTAIN SEARCH FOR ENVIRONMENTAL QUALITY 265-66 (1974))).

215. 410 U.S. 719, 735 (1973) (Douglas, J., dissenting).

216. 410 U.S. 743, 745 (1973) (Douglas, J., dissenting).

217. See Associated Enters., 410 U.S. at 744-45; Salyer Land Co., 410 U.S. at 733. 
ests of people generally to invoke the principles of Avery [v. Midland County ${ }^{218}$ ] and Hadley [v. Junior College District $\left.{ }^{219}\right]^{220}$

Douglas, accordingly, referred to the "enormity of the violation of our environmental ethics." ${ }^{, 21}$ Regardless of whether one shares Douglas's ultimate view on the merits, ${ }^{222}$ his analysis correctly appreciates the environmental dimension of considering the voting rights issue before the Court.

Justice Stevens's dissenting opinion in Dolan v. City of Tigard ${ }^{223}$ likewise demonstrates how an understanding of the nature of environmental problems is relevant to legal analysis, but in a far more contemporary setting. In Dolan, Stevens stresses why government needs to be given more latitude when it is imposing restrictions to guard against environmental risks that are not fully understood:

In our changing world one thing is certain: uncertainty will characterize predictions about the impact of new urban developments on the risks of floods, earthquakes, traffic congestion, or environmental harms. When there is doubt concerning the magnitude of those impacts, the public interest in averting them must outweigh the private interest of the commercial entrepreneur. ${ }^{224}$

Notwithstanding these isolated exceptions, the trend since the 1970s has quite plainly been towards the Justices' showing little, if any, recognition of the environmental dimension of environmental law. The Justices simply do not perceive environmental law beyond its expression in some formal statutory enactments and its presentation of yet another incidental context for their resolution of what are the truly significant crosscutting issues of law and lawmaking processes. They lack any special appreciation or caring for the ends environmental law seeks to accomplish or for the challenges for lawmaking institutions and processes presented by the problems addressed by environmental law. For that same reason, the Justices have systematically lacked the broader vision necessary to decide how environmental concerns might either affect the Justices' resolution of a crosscutting

218. 390 U.S. 474 (1968).

219. 397 U.S. 50 (1970).

220. Associated Enters., 410 U.S. at 749.

221. Id. at 751 .

222. The Court has since read its rulings in these two cases narrowly and, arguably, restricted their reach at least with regard to land ownership and voting rights. See, e.g., Quinn v. Millsap, 491 U.S. 95, 104-05 (1989).

223. 512 U.S. 374 (1994).

224. Id. at 411 (Stevens, J., dissenting). Justice Stevens's majority opinion for the Court in Robertson v. Methow Valley Citizens Council, 490 U.S. 332 (1989), however, reflects less special solicitude for this feature of environmental protection law. See supra notes $69-89$ and accompanying text. 
legal issue raised in a specific environmental context or even warrant a generally applicable evolution in the Court's own thinking about the issue.

The upshot has been, in effect, a stripping of what is truly environmental about environmental law from the Court's analysis. The cost is substantial. The Court fails to consider the sheer importance of environmental protection to the issues before the Court. Even more fundamentally, the Court deprives itself of the opportunity to consider how the special challenges environmental protection presents may warrant evolution in legal doctrine in a host of relevant areas of law.

\section{RESTORING WHAT'S ENVIRONMENTAL ABOUT ENVIRONMENTAL LAW}

There are three logical steps to restoring what is environmental about environmental law in the Supreme Court. The first, of course, is to identify the features of environmental conflicts that present special challenges for their resolution. The prior analysis suggests several of these features, which are outlined more fully below.

The second step is to relate each of these basic features of environmental conflicts to the development of a legal regime. How do they present challenges to certain areas of law? How do they present challenges to certain lawmaking institutions and processes? These challenges are the source of the crosscutting legal issues that have been the inevitable incident of environmental law's emergence during the past three decades.

The third step is to persuade the Justices that they have paid too little attention to these challenges in the Court's resolution of the crosscutting legal issues. The first two steps are more abstract, theoretical undertakings. The last is more strategic in character. It involves consideration of how, in light of the severe structural limitations placed on any effort to obtain attitudinal shifts in the Justices, that objective might nonetheless be accomplished for environmental law. Each of the three steps is described in more detail below.

\section{A. What Is Environmental About Environmental Law-The Nature of Environmental Injury}

What makes environmental law distinctive is largely traceable to the nature of the injury that environmental protection law seeks to reduce, minimize, or sometimes prevent altogether. Environmental law is concerned, in the first instance, with impacts on the natural environment. Hence, although some environmental laws are concerned about human health effects, as are 
many other types of laws (e.g., food and drug, worker safety, Medicare, and food stamp programs), environmental law is concerned only about human health effects resulting from impacts on the natural environment. And, of course, many environmental laws are concerned only with those impacts and not with possible human health effects at all.

A common denominator, therefore, for environmental law is the ecological injury that serves as the law's threshold and often exclusive focus. That common denominator is also the primary source of the special challenges environmental law presents for lawmaking. Ecological injury has several recurring features that render its redress through law especially difficult. These pertain to both the "cause" and the "effect" of such injury, each of which inevitably becomes a regulatory touchstone in any legal regime for environmental protection. Some of the more obvious features are discussed below.

1. Irreversible, Catastrophic, and Continuing Injury: Environmental law is often concerned about the avoidance of irreversible, catastrophic results. The destruction of an aquifer upon which a community depends for drinking water, the erosion of soil necessary for farming that required centuries to develop, and the destruction of the ozone layer are not possibilities to be lightly taken. Such potential downsides render enormously costly any errors in decision making. Yet, while errors are costly, so too can be delays in decision making. Even the best resolution is worth little if it is developed too late to prevent a chain of events inexorably leading to ecological disaster.

Finally, a closely related trait of some environmental injury is its continuing nature. Environmental law must address harm that increases over time. The harm is dynamic and not static in character. An oil spill addressed quickly may be confined to manageable dimensions. But conversely, if not quickly addressed, it may rapidly and exponentially increase in scope to overwhelming dimensions. Legal regimes that are inherently cautious and slow to react do not readily lend themselves to the quick action often necessary in the ecological context.

2. Physically Distant Injury: Ecological injury is often not physically confineable. Actions in one location may have substantial adverse effects in very distant locations. This may be because the pollutants actually travel from one place to another. Or it may be as the result of the adverse impacts of activities in one locale on a global commons, upon the viability of which many regions are dependent.

Long-range transportation of airborne pollutants is an example of the former. ${ }^{225}$ The ozone layer in the upper atmosphere exemplifies the

225. See generally Marvin S. SOROOS, THe ENDANGered AtMOSPHere: PRESERVING A GLOBAL COMMONS 38-42 (1997). 
transboundary implications of degradation of a commons resource, as the destruction of the ozone layer by activities in one part of the world can have serious environmental and human health effects in other parts of the world. ${ }^{226}$ Global warming presents a similar physical dimension. ${ }^{227}$

For each, the associated challenges for the establishment of any legal regime are great, especially because the costs of control are imposed in one area and the benefits are enjoyed in a very different area. Such a distributional mismatch renders the adoption, implementation, and enforcement of the necessary transboundary legal rules very difficult. ${ }^{228}$ This is certainly true in the international arenas, but even far more localized spreadings of causes and effects between states and counties resist ready political resolutions.

3. Temporally Distant Injury: Much of the injury environmental law seeks to address is not imminent. Sometimes actions now may trigger the injury, but the injury itself will be realized only in the distant future. Sometimes the injury will be realized now and will increase, inexorably, over time. To the extent that the latter is occurring, this temporal character to some environmental injury may become, as a practical matter, irreversible and thus collapse into the first feature of ecological injury described above. ${ }^{229}$

This temporal feature of ecological injuries poses challenges to legal doctrine and lawmaking analogous to those presented by the "physically distant" characteristic discussed above. The same distributional mismatch is presented but even more problematically, because the benefits to be enjoyed will generally inure only to future generations lacking any representation in

226. See generally EDITH BROWN WEISS ET AL., INTERNATIONAL ENVIRONMENTAL LAW AND POLICY 641-48 (1998).

227. See id. at $679-90$.

228. See Thomas W. Merrill, Golden Rules for Transboundary Pollution, 46 DUKE L.J. 931, 932, 968-71 (1997).

229. The traditional notion of a present/future dichotomy in environmental law is persuasively challenged by Lisa Heinzerling, who demonstrates

that, in reality, the beneficial consequences of environmental regulation do not occur within a single time frame, either the present or the future, one to the exclusion of the other.... [T] he good human consequences of environmental law-ranging from reducing risk to preventing disease to forestalling death-are arrayed along a continuum stretching from the immediate present to the distant future.

Lisa Heinzerling, Environmental Law and the Present Future, 87 GEO. L.J. 2025, 2026 (1999). Heinzerling further describes how "the present and the future are as much interactive as they are sequential, and their interaction works in both directions: the future reaches into the present, and the present into the future." Id. An example of the former is current anxiety (including associated human health consequences about future harm); the latter is represented by the long interval between exposure to a hazardous substance and the clinical manifestation of the disease. See id. at 2026-27. That cause and effect in environmental law cannot, however, be accurately described by a straightforward present/future dichotomy does not eliminate the challenges presented by ecological injury's temporal feature to environmental lawmaking, which is this Article's inquiry. The more sophisticated description of that temporal feature instead increases the related challenges. 
current lawmaking fora. Such intergenerational effects raise issues regarding the propriety of "discounting" the value of future benefits (including human lives) in selecting environmental controls today ${ }^{230}$ Even more fundamentally, however, the intergenerational dimension to ecological injury raises basic questions regarding the moral responsibilities that current generations have to safeguard the interests of future generations. ${ }^{231}$

4. Uncertainty and Risk: There is much uncertainty associated with environmental injury, which poses even further challenges for lawmaking. ${ }^{232}$ The primary source of this uncertainty is the sheer complexity of the natural environment and, accordingly, how much is still unknown about it. This uncertainty expresses itself in our inability to know beforehand the environmental impact of certain actions. It equally undermines our ability to apprehend, after the fact, what precisely caused certain environmental impacts.

The inevitable upshot is that environmental laws that seek to prevent harm are directed to risk rather than to actual impact. It similarly means that environmental laws that seek to assign responsibility for harm that has already occurred are limited in their ability to do so.

Because, moreover, environmental law is concerned with risk, there is an inherently psychological dimension to the injury being redressed. The injury is not confined to that which occurs if the risk is itself realized. There is often psychological harm resulting from the risk itself, whether or not ever realized. For this same reason, by failing to address that mental dimension, one can increase the associated injury even if the numerical probability of the risk's physical realization remains the same.

5. Multiple Causes: Ecological injuries are rarely the product of a single action at an isolated moment of time. Putting aside the pervasive uncertainty issues, environmental harms are more typically the cumulative and synergistic result of multiple actions, often spread over significant time and space. This is primarily traceable to the sharing inherent in any common natural resource base, which is the object of so many simultaneous and sporadic actions over time and space.

230. See id. at 2069-74; see also Lisa Heinzerling, Discounting Our Future, 34 LAND \& WATER L. REV. 39, 39-40 (1999). But see John J. Donohue 111, Why We Should Discount the Views of Those Who Discount Discounting, 108 YALE L.J. 1901, 1903 (1999) (responded to in Lisa Heinzerling, Discounting Life, 108 YALE L.J. 1911 (1999)).

231. See Edith Brown Weiss, The Planetary Trust: Conservation and Intergenerational Equity, 11 ECOLOGY L.Q. 495, 499-502 (1984). See generally EDITH BROWN WEISS, IN FAIRNESS TO FUTURE GENERATIONS (1989).

232. See Howard A. Latin, The "Significance" of Toxic Health Risks: An Essay on Legal Decisionmaking Under Uncertainty, 10 ECOLOGY L.Q. 339, 339-40 (1982). 
6. Noneconomic, Nonhuman Character: Many of the ecological injuries resulting from environmental degradation are not readily susceptible to monetary valuation and have a distinctively nonhuman character. There is simply no readily available market analogue. The nonexclusive nature of the natural resources at stake is often one factor prompting resistance of valuation. Even more generally, the decision to protect the ecological interest in question may have been deliberately made notwithstanding any notion of economic value. lt could, of course, be ultimately rooted in notions of uncertainty and concerns about adverse human health affects-e.g., the after-the-fact discovery that the DNA of a subspecies of fly would have cured the common cold. But it may instead be, and often is, based on the deeper notion that there are certain results-such as species extinction or resource destruction - that humankind should strive to avoid because they fall beyond its legitimate authority. ${ }^{233}$

Other kinds of injury that resist ready monetary valuation are the adverse human health effects that can result from environmental degradation, although these valuation issues are shared by all laws designed to safeguard human health. For some economists, all human health effects of this kind must be susceptible to such valuation for the simple reason that tradeoffs are inevitably made in any allocation of limited societal resources. Nothing has infinite value, and each decision has opportunity costs related to opportunities thereby foregone. But some environmental laws reflect a very different philosophy, which posits that there are some adverse human health effects that are presumptively out of bounds for policymakers. For those who share that policy view, economic valuation and tradeoffs are therefore not legitimate topics for policy discussion.

Perhaps, moreover, it is this normative dimension of ecological injury that is ultimately the most telling. The environmental dimension of environmental law teaches that the nonhuman, nonmonetizable dimensions of ecological injury not only exist but are worth protecting. They reflect positive values that are entitled to weight in the balancing in which members of the executive, legislative, and judicial branches are ultimately engaged as part of their respective lawmaking and policymaking responsibilities.

\section{B. Challenges for Law and Lawmaking}

Because of these varied features of ecological injuries, the challenges of constructing a legal regime for environmental protection are considerable.

233. See Frederick R. ANDERSON ET AL., ENVIRONMENTAL PROTECTION: LAW AND POLICY 1 (3d ed. 1999) ("[T]he primary thrust of environmentalism is not the enhancement of human dignity, but the need for humankind to subordinate itself to two communities with no legal personality, one human-future generations-and the other nonhuman-ecosystems."). 
Some of the challenges affect substantive areas of law. Others pertain more to the process of lawmaking and the related institutions than to any distinct area of law. In certain circumstances, a full appreciation of the associated challenges may well justify a modification of current law or the functioning of certain lawmaking institutions, but confined to the environmental context. In other circumstances, however, the lessons to be learned from environmental law may have more far-reaching import. They may suggest that an entire area of law, or the ways in which particular lawmaking institutions operate, should be rethought.

\section{Legal Doctrine}

The number of areas of law crosscutting with environmental law is so great and far-flung that an exhaustive discussion cannot be undertaken here. The four areas discussed briefly below-Article III standing, property, dormant commerce clause, and corporate law-are simply illustrative. Similar narratives could be drafted regarding many other crosscutting areas of law, ${ }^{234}$ such as bankruptcy law, ${ }^{235}$ civil rights law, ${ }^{236}$ criminal law,${ }^{237}$ insurance, ${ }^{238}$ remedies, ${ }^{239}$ securities, ${ }^{240}$ or tort law. ${ }^{241}$

Article III Standing: The law of standing is one obvious legal doctrine for which the nature of ecological injury is peculiarly relevant. Standing law is concerned with the existence of an "injury" in the first instance, with the action of the defendant's being a "cause" of that injury, and with the injury's

234. See generally Lazarus, supra note 211.

235. See generally Arlene Elgart Mirsky et al., The Interface Between Bankruptcy and Environmental Laws, 22 CHEMICAL WASTE LITIG. REP. 311 (1991); Douglas P. DeMoss, Note, The Bankruptcy Code and Hazardous Waste Cleanup: An Examination of the Policy Conflict, 27 WM. \& MARY L. REV. 165 (1985).

236. See generally Sheila Foster, Justice from the Ground Up: Distributive Inequities, Grassroots Resistance, and the Transformative Politics of the Environmental Justice Movement, 86 CAL. L. REV. 775 (1998); Richard J. Lazarus, Pursuing "Environmental Justice": The Distributional Effects of Environmental Protection, 87 NW. U. L. REV. 787 (1993).

237. See generally Lazarus, supra note 211.

238. See generally Kenneth S. Abraham, Environmental Liability and the Limits of Insurance, 88 COLUM. L. REV. 942 (1988).

239. See gencrally Daniel A. Farber, Equitable Discretion, Legal Duties, and Environmental Injunctions, 45 U. PITT. L. REV. 513 (1984); Zygmunt J.B. Plater, Statutory Violations and Equitable Discretion, 70 CAL. L. REV. 524 (1982).

240. See generally Perry E. Wallace, Disclosure of Environmental Liabilities Under the Securities Laws: The Potential of Securities-Market-Based Incentives for Pollution Control, 50 WASH. \& LEE L. REV. 1093 (1993); Cynthia A. Williams, The Securities and Exchange Commission and Corporate Social Transparency, 112 HARV. L. REV. 1197 (1999).

241. See generally Troyen A. Brennan, Environmental Torts, 46 VAND. L. REV. 1 (1993). 
susceptibility to "redress" through the lawsuit. ${ }^{242}$ The special features presented by ecological injury speak to each of these three inquiries (injury, cause, and redress).

The Court's treatment of standing in environmental cases, however, reveals little appreciation (or responsiveness) to the nature of ecological injury. To be sure, the Court initially expanded injury cognizable for standing to include the kind of ecological, aesthetic harms frequently at issue in environmental cases. ${ }^{243}$ The Court likewise took some account of the inevitably uncertain and speculative nature of such injuries, in particular, the more attenuated chains of causation between action and injury. ${ }^{244}$

More recently, however, the Court has decidedly retreated from some of its original responsiveness. ${ }^{245}$ The Court has taken principles of standing law, typically first announced in other legal contexts, ${ }^{246}$ and then rigidly applied them to the environmental context. Virtually no effort has been made to consider how certain features of ecological injuries, such as uncertain and attenuated chains of causation, noneconomic character, and unrepresented future generations, render their rigid application inappropriate. Until very recently, ${ }^{247}$ the trend in the Court's rulings has been so plain and disproportionately prejudicial to environmental concerns that Justice Blackmun questioned openly in dissent why the Court was so systematically disfavoring environmental plaintiffs in the law of standing. ${ }^{248}$

242. See, e.g., Valley Forge Christian College v. Americans United for Separation of Church and State, Inc., 454 U.S. 464, 471-74 (1982).

243. See Sierra Club v. Morton, 405 U.S. 727, 734 (1972).

244. See United States v. Students Challenging Regulatory Agency Procedures (SCRAP), 412 U.S. $669,686-88(1973)$.

245. See Steel Co. v. Citizens for a Better Env't, 523 U.S. 83, $102-04$ (1998); Lujan v. Defenders of Wildlife, 504 U.S. 555, 559-62 (1992); Lujan v. National Wildlife Fed'n, 497 U.S. 871, 882-89 (1990).

246. See, e.g., Simon v. Eastern Ky. Welfare Rights Org., 426 U.S. 26 (1976); O'Shea v. Littleton, 414 U.S. 488 (1974); Linda R.S. v. Richard D., 410 U.S. 614 (1973).

247. Just as this Article was going to final press, the Supreme Court decided Friends of the Earth, Inc. v. Laidlaw Envtl. Servs. (TOC), Inc., No. 98-822, 2000 U.S. LEXIS 501 (U.S. Jan. 12, 2000). The Court in Friends of the Earth dramatically rejected mootness and standing defenses raised by industry in a citizen suit brought by Friends of the Earth pursuant to the federal Clean Water Act of 1977, Pub. L. No. 95-217, 91 Stat. 1566. The Court's ruling marks a significant retreat from some of the broader implications in the Court's recent standing precedent, adverse to environmental citizen suit plaintiffs, discussed in this Article's text. The Court's having done so, however, does not detract from the Article's ultimate thesis. The favorable result obtained in Friends of the Earth was the product of the very kind of coordinated, strategic litigation effort on behalf of environmental protection concerns that this Article advocates. See infra note 328.

248. See Lujan, 504 U.S. at 606 (Blackmun, J., dissenting) ("I cannot join the Court on what amounts to a slash-and-burn expedition through the law of environmental standing."). See generally JOHN D. ECHEVERRIA \& JON T. ZEIDLER, BARELY STANDING: THE EROSION OF CITIZEN "STANDING" TO SUE TO ENFORCE FEDERAL ENVIRONMENTAL LAW (Georgetown University Law Ctr. Envtl. Policy Project 1999). 
For example, the Court requires that a plaintiff alleging injury to the natural environment, such as a wildlife species, possess some particularized professional or direct physical relation to the species at issue. ${ }^{249}$ The Court thus too swiftly denies the legitimacy of the very psychological and emotional tie to aspects of the natural environment that Congress sought to legitimize by enacting the Endangered Species Act and its citizen suit provision. ${ }^{250}$

The Court's causation inquiry similarly fails to account for the nature of ecological injury. Prompted by the Court's recent precedent denying environmental citizen suit standing, many lower courts are refusing to accommodate the uncertain nature of the causal chains associated with much ecological injury. They are demanding that plaintiffs establish more than a violation of allowable discharges; they must further allege and prove that those violations will cause certain adverse effects on the environment and that those effects will cause some particularized harm to the plaintiffs. ${ }^{251}$ Such showings are not only extremely difficult because of scientific uncertainty and ecological complexity, but they further contradict the statutory scheme Congress established. In the Clean Water and Clean Air Acts, for example, Congress deliberately decided that a statutory violation should not require such a showing of an actual ecological impact. Congress did so precisely because of the massive difficulry of such a showing and Congress's concomitant policy determination to guard against risk qua risk. By nonetheless demanding that a plaintiff show such injury to possess standing, a court both ignores the nature of ecological injury and, by frustrating congressional policy, potentially raises another set of separation of powers concerns. ${ }^{252}$

Similar tensions arise from other aspects of the Supreme Court's recent efforts to reinvigorate the law of standing. The Court's test for "imminence" is difficult to apply in environmental cases in which the ecological injury at

249. See Lujan, 504 U.S. at 562-67.

250. In enacting the Endangered Species Act (ESA), Congress plainly was not simply responding to the narrow category of concerns represented by those very few individuals who might have actual, immediate plans to travel to the precise location where the species is located and interact there with individual members. Congress instead was responding to the broader category of persons who care deeply about the survival of those species for any of a number of reasons, ranging from scientific interest to deeply held views of the responsibilities of humankind to other species. Such a concrete, individualized concern need not be based on the party's having the personal resources necessary for actual travel and some sort of a physical communing with the species. By its terms, moreover, the ESA explicitly authorizes persons to initiate citizen suits against those in violation of the statute, without statutorily restricting in any manner the precise nature of the concrete injury required for Article 111 standing. See 16 U.S.C. $\$ 1540(\mathrm{~g})$.

251. See, e.g., Friends of the Earth, lnc. v. Gaston Copper Recycling Corp., 179 F.3d 107, 113 (4th Cir. 1999); Public Interest Research Group, Inc. v. Magnesium Elektron, Inc., 123 F.3d 111, 119-25 (3d Cir. 1997); Florida Audubon Soc'y v. Bentsen, 94 F.3d 658, 666-72 (D.C. Cir. 1996).

252. See Richard J. Pierce, Jr., Causation in Government Regulation and Toxic Torts, 76 WASH. U. L.Q. 1307, 1336 (1998). 
issue is long-term in nature. ${ }^{253}$ So too problems arise in applying the Court's stricter notions of "redressability."254 If, as often occurs with ecological injuty, there is not a single action and impact, but a chain of interrelated actors and actions, it can be quite speculative to posit that relief against any one of several responsible causes is likely to secure the required redress.

Property Law: The nature of ecological injuries also creates considerable pressure for change in property law doctrine. Restrictions designed to address ecological injuries invariably limit the exercise of private property rights in

253. See Lujan, 504 U.S. at 564 . The Court has recently described the requirement that the injury be "imminent" as meaning that the injury be "certainly impending," see id. at $565 \mathrm{n} .2$ (citing Whitmore v. Arkansas, 495 U.S. 149, 158 (1990)), and has further posited that in some circumstances "we have insisted that the injury proceed with a high degree of immediacy, so as to reduce the possibiliry of deciding a case in which no injury would have occurred at all." 504 U.S. at 565 n.2. As described previously, see supra text accompanying notes 234-253, ecological injuries frequently tend to possess neither that level of certainty in their occurrence nor the temporal immediacy that the Court appears to be suggesting may be constitutionally mandated by Article III for an aggrieved plaintiff to have standing in federal court.

254. See Lujan, 504 U.S. at 568-71. The Court describes the redressability element as mandating that "it must be 'likely,' as opposed to merely 'speculative,' that the injury will be 'redressed by a favorable decision." Id. at 561 (citing Simon v. Eastern Ky. Welfare Rights Org., 426 U.S. $26,38,43$ (1976)). Because, however, ecological injury frequently is not traceable to just one actor, but results from the cumulative effects of multiple actors subject to overlapping regulatory jurisdictions, a rigorous showing of redressability is not so simply demonstrable. Most recently, moreover, the Court's unduly rigid application of the redressability element of standing in cases such as Steel Co. v. Citizens for a Better Environment, 523 U.S. 83 (1998), is prompting further arguments to the Court that Congress's entire scheme for citizen suit enforcement of environmental law is unconstitutional because it fails to satisfy redressability requirements (because fines received go to the U.S. Treasury and not to the citizen plaintiffs). See Amicus Brief for California Ass'n of Sanitation Agencies at 12-16, Friends of the Earth, lnc. v. Laidlaw Envtl. Servs. (TOC), Inc., No. 98-822, 2000 U.S. LEX1S 501 (U.S. Jan. 12, 2000). In its recent ruling in Friends of the Earch, the Court declined the invitation of amicus to consider the threshold issue of the constitutionality of citizen suits, presumably because the issue had not been raised in or decided by the lower courts in that case; nor had the parties raised it before the Supreme Court. Justice Scalia's dissenting opinion in Friends of the Earth, joined by Justice Thomas does, however, reflect such constitutional concerns. See id. at *65 (Scalia, J., dissenting) ("The new standing law that the Court makes-like all expansions of standing beyond the traditional constitutional limits-has grave implications for democratic governance."). But even more significantly, although Justice Kennedy joined the Friends of the Earth majority opinion, he also wrote separately for the sole purpose of acknowledging that

[d]ifficult and fundamental questions are raised when we ask whether exactions of public

fines by private litigants, and the delegation of Executive power which might be infer-

able from the authorization, are permissible in view of the responsibilities committed to

the Executive by Article 11 of the Constitution of the United States.

Id. at *56 (Kennedy, J., concurring). Justice Kennedy concluded that the issues would be "best reserved for a later case" because "[t]he questions presented in the petition for certiorari did not identify these issues with particularity; and neither the Court of Appeals in deciding the case nor the parties in their briefing before this Court devoted specific attention to the subject." Id. at *56-*57 (Kennedy, J., concurring). 
natural resources. ${ }^{255}$ These limitations disrupt, sometimes severely, settled economic expectations in those resources. The distributional repercussions are considerable, and they fuel major conflicts in various political arenas regarding how private property rights in natural resources should be defined and protected. ${ }^{256}$ ln extreme circumstances, moreover, those on the losing end of the policy determinations file lawsuits challenging any resulting limitations on their exercise of property rights as unconstitutional Fifth Amendment takings of private property requiring the payment of just compensation..$^{257}$

The associated controversy for property rights is exacerbated because of the uncertain nature of the ecological injury that serves as the basis for environmental restrictions. Such uncertainty makes it difficult in either a political or a judicial arena for the restrictions' proponents to establish their necessiry. ${ }^{258}$ Especially because of the need to avoid irreversible and catastrophic results, the restrictions need to be imposed before one can be confident of their necessity or efficacy.

In addition, precisely because the restrictions are based on uncertain information in the first instance, they often change over time. Initial experimental environmental regulatory programs are constantly revised in light of new information, as they should be, which is why environmental law has been so dynamic during the past thirty years. ${ }^{259}$ But, what may represent a sound dynamic process for lawmaking can nonetheless even further undermine investments by private parties made in reliance on certain environmental restrictions' remaining in place.

In addressing the regulatory takings issue, however, the Justices have maintained assumptions that fly squarely in the face of the kind of ecological injuries that Congress and various state and local legislatures seek to address. For example, in Lucas, in which a landowner brought a Fifth Amendment

255. See, e.g. J. Peter Byrne, Green Property, 7 CONST. COMMENTARY 239, $241-43$ (1990); David B. Hunter, An Ecological Perspective on Property: A Call for Judicial Protection of the Public's Interest in Environmentally Critical Resources, 12 HARV. ENVTL. L. REV. 311, 312-13 (1988).

256. See infra text accompanying notes 319-323.

257. See, e.g., Suitum v. Tahoe Reg'l Planning Agency, 520 U.S. 725, 729-33 (1997); Lucas v. South Carolina Coastal Council, 505 U.S. 1003, 1007-10 (1992); Keystone Bituminous Coal Ass'n v. DeBenedictis, 480 U.S. 470, 478-79 (1987).

258. Justice Stevens's dissent in Dolan v. City of Tigard, 512 U.S. 374, 396 (1994) (Stevens, J., dissenting), comments on this very issue. See supra text accompanying notes 223-224.

259. See RODGERS, supra note $108, \S 1.2$, at 25 (noting that the environmental law field is marked by "dynamics and flux where a regulation is inseparable from a revision, a statute not far from an amendment"); Daniel A. Farber, Environmental Protection as a Learning Experience, 27 LOY. L.A. L. REV. 791, 791 (1994) (noting that in environmental law "every solution seems provisional and subject to reevaluation as new information appears and old solutions are tested against experience"); see also Daniel P. Selmi, Experimentation and the "New" Environmental Law, 27 LOY. L.A. L. REV. 1061, 1076 (1994) (advocating the need for further experimentation and fundamental change in the nature of environmental law). 
regulatory takings challenge to a South Carolina law that prevented residential development of his coastal property, the Court's regulatory takings analysis rested, at bottom, on a fundamental misapprehension of the nature of land. ${ }^{260}$ The Lucas majority perceived land as a discrete, severable resource, which is why the Court found utterly implausible the notion that South Carolina might have a reason, analogous to a traditional nuisance rationale, for preventing the construction of a home on land. What the majority lacked was any appreciation of the true physical nature of land and the associated nature of injuries to a complex, interdependent ecological system of which land is a part.

The facts of Lucas itself are illustrative. The land at issue was immediately adjacent to the shore, with no natural barriers separating the ocean from the location of the residences proposed for development. Indeed, much of the property was composed substantially of water rather than what most would consider land. The properties were subject to the daily action of the tide and, in the past, had been partially (and sometimes entirely) covered by water. During the past fifty years, the shoreline had itself been landward of the landowner's property 50 percent of the time because of the competing forces of accretion and erosion. Absent any meaningful understanding of the actual physical nature of the ecological resource, the injuries possibly resulting from its development, and, therefore, the state legislature's possible justifications for its action, the Lucas majority too quickly perceived the case as one presenting an extraordinarily harsh instance of governmental abuse of police power authority. ${ }^{261}$

The Justices rely, moreover, on tests of "economic viability" and "economic loss" that, at bottom, depend for their validity on the operation of the very market that the legislature is saying does not provide a fair measure of the property rights at issue. ${ }^{262}$ The legislative premise of most environmental restrictions is that property rights need to be redefined because the current regime permits certain private actions that have unacceptably adverse effects on others. Accepting the validity of that legislative premise, one would anticipate that any diminutions in property value resulting from such restrictions on use would signal the extent to which such a regulatory fix was, in fact, necessary. In other words, the higher the prerestriction market value of the property to be regulated, the greater the problem being addressed.

Yet the "economic viability" and "economic loss" inquiries presume just the opposite. They see economic loss as a sign of legislative overreaching

260. See Lucas, 505 U.S. 1003 (1992).

261. See Richard J. Lazarus, Putting the Correct "Spin" on Lucas, 45 STAN. L. REV. 1411, 1421$22(1993)$.

262. See 505 U.S. at 1014-19. 
rather than as a sign that the legislature was addressing a major problem of market failure. ${ }^{263}$

As in the law of standing, the Court should not, of course, wholly defer to the legislature's judgment any more than it should wholly ignore it. The Court has an independent responsibility to ensure that important constitutional protections, such as those related to private property rights, are safeguarded. But fulfillment of that responsibility does not justify the Justices' paying no heed to the factual and public-policy premises underlying the environmental legislation that serves as the backdrop to the Court's resolution of the legal issue before it. Just as Congress has sought to account for the nature of ecological injury in establishing environmental protection law, so too should the Court, both in discerning congressional intent and in resolving crosscutting legal issues arising in the environmental context.

Dormant Commerce Clause: During the past two decades, the Court has faced a series of cases involving dormant commerce clause challenges to state environmental protection and resource conservation laws that seek to protect the state's own environmental and economic interests from threats perceived as originating from out-of-state sources. These include state laws concerned about the importation of waste into the state from out-of-state sources. They also include state laws concerned about the exportation of the state's valuable natural resources.

With a few rare exceptions, ${ }^{264}$ the Court has routinely struck down both state resource conservation and state pollution control laws as facially discriminatory and, thus, per se violations of the negative implications of the Commerce Clause. ${ }^{265}$ The Court's analysis of facially discriminatory laws,

263. The Court's regulatory takings analysis also relies on rigorous showings of proof of causation and redressability that, as in the case of standing law, are fundamentally at odds with the nature of the injuries the legislature is seeking to address. See Dolan, 512 U.S. at 388-96.

264. One noted exception is the Court's ruling in Maine v. Taylor, 477 U.S. 131, 151-52 (1986), sustaining the state of Maine's ban on the importation of baitfish. 1ndeed, Maine v. Taylor represents one of the rare instances in which the Court's opinion expresses an appreciation for how environmental concerns may influence the application of legal doctrine. One reason the Court offered for sustaining Maine's importation ban was the legitimacy of the state's interest "in guarding against imperfectly understood environmental risks, despite the possibility that they may ultimately prove to be negligible." Id. at 148. According to the Court, a state is not required to "wait until potentially irreversible environmental damage has occurred." Id. (quoting United States v. Taylor, 585 F. Supp. 393, 397 (D. Me. 1984)). Another exception is Commonwealth Edison Co. ข. Montana, 453 U.S. 609, 636-37 (1981), in which the Court upheld the constitutionality of a state severance tax on coal challenged on both Commerce Clause and federal preemption grounds. Reflecting the strong temporal dimension of ecological injury, the Court in Commonwealth Edison took explicit account of the state's desire to safeguard the interests of future generations in the state's resource wealth, which the coal severance tax sought to accomplish by creating a trust fund for future generations. See id. at $621 \mathrm{n} .11$.

265. See, e.g., C\&A Carbone, Inc. v. Town of Clarkstown, 511 U.S. 383, 389-95 (1994); Oregon Waste Sys., Inc. v. Department of Envtl. Quality, 511 U.S. 93, 98-108 (1994); Fort 
such as those at issue in all these cases, is wholly unforgiving. To sustain any facial discrimination against interstate products (including waste) or services, the state government must proffer "some reason, apart from their origin, to treat them differently."266

The Court's rulings, however, provide yet another classic instance in which the Justices' failure to appreciate the special character of ecological injuries undermines the Court's legal analysis. The Court irrebuttably presumes the illegitimacy of any consideration of the outsider status of the products or services at issue. Yet, in the environmental pollution context, "the very concept of the 'risk' appropriate for regulatory treatment may depend on the place in which a given risk originates. ${ }^{267}$ As one commentator explains:

Several of the attributes that make laypeople fear some activities or substances more than others (even if they pose the same statistical risk of physical harm) are intertwined with outsider status.... The likelihood of public opposition to a new waste disposal facility stems in large part from the sense of "intrusion" a community feels on account of the facility. The depth of this sense of intrusion depends in part on the presence of coercion: where the community has no opportunity to reject a proposed facility ..., the community's perception of risk, and its opposition to the facility, almost inevitably will increase. ${ }^{268}$

Were the Justices to learn from the environmental context, they could consider more carefully the nature of ecological injuries being redressed by state laws in resolving dormant commerce clause challenges. They might (or might not) reach a different result in those cases. But even if they did not, their reasoning would be more thoughtful and the results they reached would likely be more persuasive. Any resulting maturation of the Court's Commerce Clause analysis, moreover, would not be confined simply to the environmental context. It would apply broadly and potentially affect the Court's decisions in wide-ranging circumstances. ${ }^{269}$

Gratiot Sanitary Landfill, Inc. v. Michigan Dep't of Natural Resources, 504 U.S. 353, 367-68 (1992); Chemical Waste Management, Inc. v. Hunt, 504 U.S. 334, 339-49 (1992); Sporhase v. Nebraska ex rel. Douglas, 458 U.S. 941, 954-58 (1982); Hughes v. Oklahoma, 441 U.S. 322, 325 (1979); City of Philadelphia v. New Jersey, 437 U.S. 617, 629 (1978).

266. City of Philadelphia, 437 U.S. at 627 (emphasis added).

267. Lisa Heinzerling, The Commercial Constitution, 1995 SUP. CT. REV. 217, 236.

268. Id. at 236-37. Nor is this "outsider" dimension to environmental law an incidental matter. It is a driving concern in many of the claims of "environmental injustice," which both federal and state regulators, as well as members of the regulated community, are increasingly having to address. See generally Eileen Gauna, The Environmental Justice Misfit: Public Participation and the Paradigm Paradox, 17 STAN. ENVTL. L.J. 3 (1998).

269. See Heinzerling, supra note 267, at 239 ("The shortcomings of the Court's truncated cost-benefit analysis are not limited to the environmental context."). 
Corporate Law: Corporate law offers one final example of an area of law in which the Justices' legal analysis has been undermined by their disinclination to consider the distinct features of the kinds of problems environmental law seeks to address. In a recent case, United States v. Bestfoods, ${ }^{270}$ the Court considered the liability under the Comprehensive Environmental Response, Compensation, and Liability Act of 1980 (CERCLA) $)^{271}$ of a parent corporation for the actions of a subsidiary. ${ }^{272}$ For years, the various courts of appeals sought, with conflicting results, ${ }^{273}$ to strike a balance between the values and purposes of corporation law, which promotes severe limitations on parent liability, and of environmental law, which seeks to impose costs on a broad array of economic actors with the authority and capacity to make decisions affecting the degree of environmental protection to be provided.

What was both striking and revealing about the oral argument before the Court was that the Justices were uniformly aware and sympathetic to the important policy objectives underlying corporate law's limited liability rules; they were not, however, similarly aware of environmental law's competing concerns supporting a more expansive liability net. Indeed, members of the Court appeared completely shocked when informed of those principles and their settled legal effect by government counsel at argument. ${ }^{274}$ The

270. 524 U.S. 51 (1998).

271. 42 U.S.C. $\$ \$ 9601-9675$ (1994).

272. See 524 U.S. at 55.

273. See id. at 60 n.8, 63 n.9; Lynda J. Oswald, Bifurcation of the Ouner and Operator Analysis Under CERCLA: Finding Order in the Chaos of Pervasive Control, 72 WASH. U. L.Q. 223, 225-26 (1994); Note, Liability of Parent Corporations for Hazardous Waste Cleanup and Damages, 99 HARV. L. REV. 986, 1001 (1986).

274. The following colloquy occurred during the government's opening presentation in the Bestfoods oral argument:

QUESTION [Justice Breyer]: Look, I said Mr. and Mrs. Smith and their son, John, do everything. They have a shovel. They put the dirt in. They do everything them selves. They are doing it through-they are paid—the checks are made out to the Smith Family Limited Liability Corporation.

Now, I would think that that is the classic situation of where a group of people form a corporation to limit their liability. That's why we have corporations.

Is there any suggestion in what you say that the Smith family is personally liable? Nothing special's going on. It's ordinary.

MS. SCHIFFER [Counsel for the United States]: Any facility can have more than one operator, Your Honor, and it is our view that if Mr. and Mrs. Smith themselves personally operated the facility, that is, actively participated in the management of the facility, that they would be liable.

....

QUESTION: So your view is that if a group of people incorporate themselves and they personally operate the dump, they are personally liable, so in this statute alonel've never seen another stature like that-there is no way for a group of operators to form a corporation and therehy exempt themselves from personal liability. 
Justices regained their equilibrium, ironically, only when industry counsel candidly acknowledged that the government's answer was not at all radicali ${ }^{275}$ it merely reflected settled principles of environmental law established by Congress through its legislative enactments and long sustained by the lower courts. Those courts were responding to the fact that decisions affecting environmental quality are often the product of decisions being made by multiple actors. In the complex setting of contemporary corporate decision making marked, as in Bestfoods, by parent, subsidiary, and successor corporations and overlapping corporate officers and boards of directors, notions of individual responsibility are invariably undermined as is, therefore, the ability of legal rules to deter undesirable conduct.

Of course, whether such a policy concern provides sufficient reason to modify traditional limitations on corporate liability in the environmental context is entirely up to Congress. And, for that same reason, whether Congress has done so in CERCLA or in any other federal environmental law is simply a matter of discerning congressional intent. In Bestfoods, however, there was a marked imbalance to the Court's apprehension of the policy concerns implicated by CERCLA. The Court was essentially unaware of the legitimate policy reasons why Congress might have decided to expand corporate liability in CERCLA, yet simultaneously quite aware of the policy justifications for limiting corporate liability. Not surprisingly, the Court's resulting construction of CERCLA was inevitably skewed in favor of a construction that promoted the latter. The Court required, in effect, those arguing for

I mean, is-that's the view of the Government? Because I would have thought that if that's the view you would have expected Congress to say something about that rather unusual-I think it would be unusual.

Official Transcript of the Oral Argument before the United States Supreme Court at 16-18, United States v. Bestfoods, 524 U.S. 51 (1998) (No. 97-454), available in 1998 U.S. Trans. LEXIS 61. The identities of the Justices appearing in the brackets do not appear in the official transcripts. They are based on my contemporaneous notes taken at the oral argument before the Court.

275. During industry counsel's oral argument, Justice Stevens returned to Justice Breyer's earlier hypothetical posed to the government, apparently in an effort to emphasize to the other Justices that the government's characterization of the Comprehensive Environmental Response, Compensation, and Liability Act of I980's (CERCLA's) impact on notions of limited corporate liability was not in fact so extraordinary:

QUESTION [Justice Stevens]: Let me be sure I understand your position, Mr. Geller. You take Justice Breyer's hypothetical and say yes, Mr. and Mrs. Smith and their son would be liable, if I understand your-

MR. GELLER: If they were actually physically engaged in operating the facility, they would fall within the statute, I would think, but that's not-

QUESTION: So that any employee of a corporation with a facility can be liable?

MR. GELLER: If someone satisfies the definition of operator, they're liable . . . .

Id. at 27 . 
more expansive liability to overcome a judicially erected presumption favoring limited liability. ${ }^{276}$

\section{Lawmaking Institutions and Processes}

The evolutionary reach of environmental law is not, moreover, confined to crosscutting areas of law. It extends to lawmaking institutions and processes as well. Here, too, the problems environmental law seeks to address pose peculiar challenges for those institutions and processes, creating the need as well as the opportunities for innovation and reform. ${ }^{27}$

One can commence with an aspect of government as fundamental as our system of checks and balances between branches of government. Such a tripartite system of government is by deliberate design conservative, favoring incremental change. Yet environmental problems often urge quick action to avoid possible catastrophic and irreversible results. They also require a degree of ongoing revision and fine-tuning in light of changing and uncertain information that often resists the kind of sharp delineations between those who legislate and those who merely execute the laws. It is for this reason that long-moribund nondelegation issues have recently arisen in the environmental context. ${ }^{278}$

When, moreover, Congress seeks to create constitutional shortcuts in order to control the other two branches of government, such legislative efforts raise their own significant separation of powers concerns. This has occurred in environmental law with congressional efforts to oversee the executive ${ }^{279}$ as well as the judicial branch. ${ }^{280} \mathrm{It}$ is no mere happenstance that a case as infamous as Morrison v. Olson, ${ }^{281}$ concerning the constitutionality of the

276. See 524 U.S. at 70 ("There would in essence be a relaxed, CERCLA-specific rule of derivative liability that would banish traditional standards and expectations from the law of CERCLA liability. But, as we have said, such a rule does not arise from congressional silence, and CERCLA's silence is dispositive.").

277. One innovation rejected early on by the Supreme Court was the D.C. Circuit's effort to impose heightened procedural requirements in certain environmental cases. See Vermont Yankee Nuclear Power Corp. v. Natural Resources Defense Council, Inc., 435 U.S. 519, 523-25 (1978).

278. See American Trucking Ass'ns v. EPA, 175 F.3d 1027, 1034-40, reh'g granted in part and denied in part, 195 F.3d 4 (D.C. Cir. 1999); South Dakota v. United States Dep't of the Interior, 69 F.3d 878, 881-82 (8th Cir. 1995), vacated and remanded, 519 U.S. 919 (1996); see also Industrial Union Dep't v. American Petroleum Inst., 448 U.S. 607, 646-52 (1980); id. at 672-76 (Rehnquist, J., concurring).

279. See Federal Land Policy \& Management Act of 1976, 43 U.S.C. $\$ 1714(c)(1),(d),(1)(2)$ (1994) (providing for congressional committee oversight of secretary of the interior determinations regarding the withdrawal of public lands from disposition laws); see also National Wildlife Fed'n v. Watt, 571 F. Supp. 1145, 1150-51 (D.D.C. 1983).

280. See, e.g., Robertson v. Seattle Audubon Soc'y, 503 U.S. 429, 433-36 (1992).

281. 487 U.S. 654 (1988). 
independent counsel law, arose out of a conflict between the legislative and executive branches regarding environmental policy. ${ }^{282}$ Nor is it similarly coincidental that the leading case pertaining to standards of judicial review of agency statutory interpretation, Cherron U.S.A. Inc. v. NRDC, ${ }^{283}$ involved the EPA's changing its mind concerning the meaning of a federal environmental protection law. ${ }^{284}$ Such experimentation and policy reversals are the natural byproduct of any good-faith efforts to address complex problems, such as those presented by environmental pollution, when scientific uncertainty is great and the relative differences in the costs of alternative approaches are quite large.

Similar tensions arise because of the nation's commitment to multiple sovereign authorities, including federal, state, and local governments and, increasingly, tribal authorities as well. ${ }^{285}$ There is at one level a natural affinity between the resolution of environmental problems and a general bias favoring decentralized legal regimes: It more easily allows for the resolution of environmental problems to take localized circumstances, both ecological and anthropological, into account. ${ }^{286}$ It is also more consistent with growing demands for meaningful public participation, most recently by environmental justice advocates. ${ }^{287}$

Many environmental problems, however, strongly resist such decentralized approaches. They do so largely because of their sweeping spatial and

282. The independent counsel investigation at issue in Morrison arose out of congressional efforts to oversee the EPA's administration of federal hazardous-waste policy, especially in the area of enforcement. See id. at $665-66$.

283. 467 U.S. 837 (1984).

284. The validity of the regulation at issue in Cherron turned on the EPA's construction of the term "source" in the Clean Air Act, which the EPA had previously construed differently. See id. at 853-59.

285. See generally Daniel C. Esty, Revitalizing Environmental Federalism, 95 MiCH. L. REV. 570 (1996); Robert V. Percival, Environmental Federalism: Historical Roots and Contemporary Models, 54 MD. L. REV. 1141, 1157-71 (1995); Richard L. Revesz, Rehabilitating Interstate Competition: Rethinking the "Race-to-the-Bottom" Rationale for Federal Environmental Regulation, 67 N.Y.U. L. REV. 1210 (1992); Richard B. Stewart, Pyramids of Sacrifice? Problems of Federalism in Mandating State Implementation of National Environmental Policy, 86 YALE L.J. 1196 (1977).

286. See Esty, supra note 285, at 609-10, 648-49; Richard J. Lazarus, Debunking Environmental Feudalism: Promoting the Individual Through the Collective Pursuit of Environmental Quality, 77 IOWA L. REV. 1739, 1773 (1992); David L. Markell, States as Innovators: It's Time for a New Look to Our "Laboratories of Democracy" in the Effort to Improve Our Approach to Environmental Regulation, 58 ALB. L. REV. 347, 355-59 (1994); Stewart, supra note 285, at 1219-22.

287. See Gauna, supra note 268, at 72 (describing the inherent "mismatch" between environmental law and policymaking processes and environmental justice because the latter's "[d]ecision-making paradigms rest on foundations that promote environmental injustice"); Anne K. No, Note, Environmental Justice: Concentration on Education and Public Participation as an Alternative Solution to Legislation, 20 WM. \& MARY ENVTL. L. \& POL'Y REV. 373, 389-92, 399-400 (1996) (advocating addressing environmental justice concerns through broader public participatory rights in environmental decision making). 
temporal scope. ${ }^{288}$ Problems of such magnitude and scope defy localized jurisdictional boundaries and shorter-term time horizons, and their resolution may offer economies of scale that favor more centralized approaches. ${ }^{289}$ The temporal and spatial spillovers are related in part to the physical character of environmental problems. Ecosystems neither mirror political jurisdictional boundaries nor reveal their injuries within time frames roughly commensurate to those necessary for voters to hold decision makers accountable in election year cycles.

Because, moreover, even small decision-making errors can pose threats of irreversible, catastrophic ecological harm occurring beyond the decision maker's own jurisdictional boundaries, the decentralization of certain kinds of environmental decision making can be especially problematic. At the very least, the essential Brandeisian observation that "[i]t is one of the happy incidents of the federal system that a single courageous State may ... try novel social and economic experiments" ${ }^{290}$ is deprived of some of its persuasive force when, as happens with environmental injuries, errors made in those laboratories can have major adverse consequences that are not confineable to the lab itself.

The spillover feature of environmental law is not, however, traceable just to the physical character of many ecological injuries. The inevitability of spillovers is further related to the nationwide scope of the market transactions and industrial practices that are the subject of environmental regulations. ${ }^{291}$ Indeed, it is the national character of the affected markets and industries, rather than the physical nature of the ecological injuries, that has prompted the Supreme Court repeatedly to invalidate as undue burdens on interstate commerce state and local governmental efforts to craft localized solutions to environmental problems. ${ }^{292}$

288. The "spillover" or "externality" feature of ecological injuries is, of course, not the only policy basis for favoring centralization of environmental lawmaking authority. There are a host of arguments for and against either centralizing or decentralizing environmental lawmaking authority, ranging from institutional competence to regulatory capture. This Article focuses only on a few, like the spillover feature, that are especially illustrative of the relationship between the nature of ecological injury to crosscutting legal issues arising in environmental law. For a fuller discussion of the broader centralization/decentralization debate, see generally Esty, supra note 285, Rena 1. Steinzor, Unfunded Environmental Mandates and the "New (New) Federalism": Devolution, Revolution, or Reform?, 81 MINN. L. REV. 97 (1996), and Stewart, supra note 285.

289. See Esty, supra note 285, at 614-17.

290. State lce Co. v. Liebmann, 285 U.S. 262, 311 (1932) (Brandeis, J., dissenting).

291. See Gerald E. Frug, Why Neutrality?, 92 YALE L.J. 1591, 1600 (1983) ("There can be no meaningfully decentralized decision making about environmental matters as long as decisions about capital mobility are centralized.").

292. See, e.g., C\&A Carbone, Inc. v. Town of Clarkstown, 511 U.S. 383, 389-95 (1994); Oregon Waste Sys., lnc. v. Department of Envtl. Quality, 511 U.S. 93, 98-108 (1994); Chemical 
A final aspect of ecological injuries that affects lawmaking institutions and processes is the schizophrenic nature of government's role in environmental protection. ${ }^{293}$ Government, whether it be federal, state, local, or tribal, is the primary regulatory authority responsible for the enactment, administration, and enforcement of environmental protection laws. This is especially so because many of the nongovernmental interests being protected by those laws are unable to bring enforcement actions on their own behalf because of the nature of the injuries being addressed. To the extent that future generations are being safeguarded, they are not yet born and therefore obviously cannot sue; to the extent that purely ecological interests are being preserved, those interests have no independent standing to sue; $;^{294}$ and to the extent that each member of the public shares an undifferentiated, generalized, interest, current Supreme Court precedent calls into question their standing to maintain an enforcement action. ${ }^{299}$

While government enforcement is essential, all of these sovereign authorities are simultaneously undertaking actions that may violate each others' environmental laws, and even their own. This raises a host of sovereign immunity issues in response to enforcement actions brought against the government. These suits may be brought by one sovereign against another and sometimes by private citizens pursuant to citizen suit provisions. $^{296}$ They may sometimes even be brought by one agency against another agency within the same sovereign, although the justiciability of such a lawsuit for the federal sovereign is disputed. ${ }^{297}$

Finally, disputes over natural resource ownership have historically involved tribes as well as federal, state and local authorities, ${ }^{298}$ while envi-

Waste Management, lnc. v. Hunt, 504 U.S. 334, 339-49 (1992); City of Philadelphia v. New Jersey, 437 U.S. 617,629 (1978).

293. See Lazarus, supra note 211 , at 2440 ("The single greatest source of institutional differentiation in environmental law is the government's schizophrenic role as both regulator and regulated, simultaneously enforcing environmental protection laws both against others and against itself as the single largest source of pollution.").

294. Cf. Christopher D. Stone, Should Trees Have Standing? - Toward Legal Rights for Natural Objects, 45 S. CAL. L. REV. 450, 456-57 (1972).

295. See Lujan v. Defenders of Wildlife, 504 U.S. 555, 573-78 (1992).

296. See, e.g., City of Chicago v. Environmental Defense Fund, 511 U.S. 328, 330 (1994); United States Dep't of Energy v. Ohio, 503 U.S. 607, 612-14 (1992); Pennsylvania v. Union Gas Co., 491 U.S. 1, 7-13 (1989); Hancock v. Train, 426 U.S. 167, 198-99 (1976); 1llinois v. City of Milwaukee, 406 U.S. 91, 93-98 (1972).

297. See Michael Herz, United States v. United States: When Can the Federal Government Sue Itself?, 32 WM. \& MARY L. REV. 893, 933-38 (1991); Michael W. Steinberg, Can EPA Sue Other Federal Agencies?, 17 ECOLOCY L.Q. 317, 331-41 (1990).

298. See, e.g., Wilson v. Omaha Indian Tribe, 442 U.S. 653, 658-60 (1979); Chemehuevi Tribe of lndians v. Federal Power Comm'n, 420 U.S. 395, 397-99 (1975); Department of Game v. Puyallup Tribe, 414 U.S. 44, 45 (1973); United States v. Southern Ute Tribe or Band of Indians, 402 U.S. 159, 159 (1971). 
ronmental pollution cases have involved only the latter. In recent years, however, the tribes have begun to assert their sovereignty in the pollution control area as well. ${ }^{299}$

There are, accordingly, a series of deeply ingrained structural reasons why the history of environmental law during the past three decades has witnessed such continuous tension and conflict between federal, state, local, and tribal authorities regarding their respective responsibilities and authorities in addressing environmental problems. So many fundamental structural lawmaking issues have arisen and continue to arise because of the types of pressures generated by the nature of the problem being addressed. There is, at bottom, a fundamental discontinuity between environmental law's aims and our nation's lawmaking regime. ${ }^{300}$

\section{Persuading the Justices}

The most obvious pathway to securing a change in attitude towards environmental law in the Supreme Court is also the most problematic: Change the identity of the Justices. Not only are such windows of opportunity highly unpredictable in their occurrence, ${ }^{301}$ but they are also deliberately shortlived in order to minimize the effectiveness of any such discrete efforts to affect the nomination process. ${ }^{302}$

299. See, e.g., South Dakota v. Yankton Sioux Tribe, 522 U.S. 329, 333-40 (1998); Back country Against Dumps v. EPA, 100 F.3d 147, 148-50 (D.C. Cir. 1996); City of Albuquerque v. Browner, 97 F.3d 415, 418-20 (10th Cir. 1996).

300. See ANDERSON ET AL., supra note 233, at 1.

The promotion of environmental protection is further complicated because environmental

law is, to a greater extent than other areas of law, a product of external forces, difficult to integrate into our legal system and limited to the extent that it seeks to impose rather than Id.

to reflect fundamental societal values.

301. What is unpredictable is the precise timing of an opening. Over longer time frames, one can fairly predict a certain number of openings, based simply on the age of the Justices. During much of the 1980s, for instance, it was quite clear that the aging of the Justices made a series of openings very likely during the 1990s. And, since Justice Brennan's retirement in 1990, four new Justices (Souter, Thomas, Ginsburg, and Breyer) have been added to the Court.

302. President Bush, for instance, strived to choose his nominees quickly, which limited opportunities to influence his decision. See, e.g., Ann Devroy, In the End, Souter Fit Politically, WASH. POST, July 25, 1990, at A1; Al Kamen \& Ruth Marcus, Marshall Retires from Divided Supreme Court: Liberal Is Second to Quit in a Year; Bush to Move Quickly on Successor, WASH. POST, June 28, 1991, at A1. President Clinton, by contrast, appears to have preferred to allow certain names of possible nominees to be floated publicly for many days so that he could better account for the political repercussions of choosing one candidate rather than another. Just such an approach reportedly led Clinton to fuel speculation about Secretary of the Interior Bruce Babbitt, New York Governor Mario Cuomo, and then-Judge Stephen Breyer before finally selecting thenJudge Ruth Bader Ginsburg as his first nominee to the Court. See MARK SILVERSTEIN, JUDICIOUS CHOICES: THE NEW POLITICS OF SUPREME COURT CONFIRMATIONS 169-71 (1994). 
There is also a relevant lesson here to be learned from the paradoxical voting patterns in environmental cases described above for most of the Justices, ranging from Chief Justice Rehnquist to Justice Stevens. ${ }^{303}$ They suggest that it will be the rare candidate that will have a clear environmental track record from which one can readily predict future votes as a Justice in environmental cases. Certainly nothing much can be fairly gleaned from the mere fact that the candidate, as a lower court judge or otherwise as a lawmaker or policymaker, seemed to rule or vote "for" or "against" the environment in a particular case or even several cases. In almost all instances, save a Justice Douglas or a Justice Scalia, there will be too few cases and too much disharmony to suggest any easily discernible pattern from which conclusions about environmental protection can reasonably or fairly be drawn.

Notwithstanding these significant threshold limitations, the Court's past three decades of precedent suggest that there are some background traits from which one might plausibly speculate that an individual would be more rather than less supportive of laws promoting environmental protection ends. These include (1) the individual's vision of the role of law in general, and of lawmaking institutions in particular, in relation to the nation's market economy, and (2) the individual's own life experiences in relation to the natural environment.

Of the two, the former would seem the most intuitive. Those who generally favor law's serving as an instrument for social change should be more sympathetic to facilitating the development of a legal regime for environmental protection. Those, by contrast, who start with the premise that the law's essential function should be to define and protect pre-existing property rights and to promote market transactions would naturally be skeptical, if not hostile, in their reception to environmental law. Justice Douglas would seem to fit the former description, while Justice Scalia plainly fits the latter. ${ }^{304}$

It is the trait relating to an individual's personal and professional experiences with the natural environment, however, that emerges most strikingly from the votes of the individual Justices during the past three decades. It is plainly no coincidence that the Justice with an EP score of 100, Justice Douglas, was an avid outdoorsman. As described by Douglas himself, "I am filled with prejudices, for I love the call of the horned owl in the darkness of night, the howl of the coyote, the call of the mourning dove, and the whistle of the bull elk." ${ }^{, 305}$ His personal experiences with the natural environment

303. See supra Part I.

304. See supra notes $127-134$ and accompanying text.

305. Peter Manus, Wild Bill Douglas's Last Stand: A Retrospective on the First Supreme Court Environmentalist, 72 TEMP. L. REV. 111, 140 (1999) (quoting William O. Douglas, The Conservation of Man 7 (unpublished, undated essay, on file with the Library of Congress, Manuscript Division)). 
made him value more highly governmental efforts designed to protect environmental amenities. They also apparently made him far more willing to accommodate other competing values, reflected in legal principles and doctrines intersecting those advanced by environmental protection laws. His near-unanimous support of environmental ends profoundly influenced both his initial framing of the issues presented and ultimately his votes on those issues.

But the lesson regarding the significance of personal experience for environmental law is not one taught just by the historically rare case of Justice Douglas. The crack in Justice Kennedy's votes generally favoring property rights over environmental protection seems directly traceable to his own experiences as a resident of California, where residents learn of the pitfalls of developing land not physically suited for residential use. ${ }^{306}$ So too, both Justice Powell's general antagonism towards pollution control laws and his contrasting sympathy towards forest protection and historic preservation would seem to derive from his personal experiences. ${ }^{307}$ His natural skepticism of the efficacy of pollution control laws most likely stemmed from his personal experiences as legal counsel for regulated industry in a private law firm. ${ }^{308}$ By contrast, one can plausibly speculate that his receptivity to historic preservation law and national forest conservation probably stems from his strong personal and professional affiliations with Colonial Williamsburg ${ }^{309}$ and his lifelong enjoyment of small-game hunting in forests. ${ }^{310}$

306. See Lazarus, supra note 261 , at 1423.

As a Californian, Justice Kennedy's insight into the desirability of environmental regulation may stem from personal experience. .. . Californians have more reason to be aware of the hidden perils in land which, to the untrained eye, might seem appropriate for unrestricted development. In California, the repeated losses of life and destruction of property caused by earthquakes, mudslides, floods, and fires serve as effective teachers.

Id.

307. Environmental law appears not to have been the only area of law in which Justice Powell's votes were profoundly influenced by his perceptions of his own life experiences, including his misperceptions of those experiences. Another, now infamous, example in civil rights law is Justice Powell's supplying of the crucial fifth vote to the majority ruling in Bowers v. Hardwick, 478 U.S. 186, 187 (1986), which upheld a state criminal conviction for homosexual sodomy. See id. at 189. Several years after that decision, Powell publicly acknowledged that he regretted his vote in Bowers. See Linda Greenhouse, When Second Thoughts in Case Come Too Late, N.Y. TIMES, Nov. 5, 1990, at A14. There is reasonable basis for speculation, moreover, that Justice Powell's original vote in Bowers resulted in part from his erroneous belief that he did not know any homosexuals, when, in fact, his own recent law clerks had included some. See JEFFRIES, supra note 137, at 52122; LAZARUS, supra note 35 , at 386.

308. See supra text accompanying notes 137-139.

309. As previously described, the special solicitude to national forests that Justice Powell displayed in United States v. New Mexico, 438 U.S. 696, 719 (1978), may well have been the product of such a personal experience. See supra notes $163-168$ and accompanying text.

310. See supra text accompanying notes 167-168. 
The votes of Justices Douglas, Kennedy, and Powell in environmental cases all lend support to a common thesis: The extent to which a person, including a Supreme Court Justice, cares about environmental protection seems especially susceptible to being defined by their own personal experiences with the natural environment. A Justice's affinity for the natural environment, in turn, influences his or her conceptualization of the legal issues presented in an environmental protection setting. For many, moreover, an appreciation of environmental law's objectives and the legitimacy and strength of the evolutionary demands that they place on competing legal doctrines and on lawmaking institutions originates in personal experience. It is apparently unlikely to be the exclusive product of abstract, dispassionate thinking wholly removed from the natural environment that serves as environmental law's core inspiration. ${ }^{311}$

Of course, environmental law is hardly unique in this regard. Much of the Court's civil rights precedent, based on the votes of the individual Justices in those cases, can be similarly explained. It is no happenstance, for instance, that Justice O'Connor's conservative tendencies are greatly tempered when the issues before the Court relate to issues of gender discrimination with which she can identify based on her own personal and professional experiences. ${ }^{312}$ The voting patterns in civil rights cases of both Justice Thurgood Marshall and Justice Thomas can be similarly explained. Their views clearly have little in common, but their respective votes nonetheless reflect the lessons each believes he learned not simply as a law student studying the law or as a practicing lawyer, but as an African American living with racism in the United States. It is precisely because many African Americans believe that Justice Thomas is not being true to those life experiences that some react with even more hostility to his votes than to those of his conservative colleagues on the Court. ${ }^{313}$

Nor is there anything untoward or improper or even necessarily intentional about such factors' influencing judicial outcomes. It is both unavoidable and entirely appropriate for judges, including Supreme Court Justices, to be influenced by their own life experiences in exercising their judgment in

311. For this reason, the environmental community has long found reason for hope in Justice Souter's apparent strong interest in hiking in the White Mountains of New Hampshire. See Fox Butterfield, Unchanged, but Growing as Justice, N.Y. TIMES, July 23, 1992, at A16; David Margolick, Ascetic at Home but Vigorous on Bench, N.Y. TIMES, July 25, 1990, at A1.

312. See Linda Greenhouse, From the High Court, a Voice Quite Distinctly a Woman's, N.Y. TIMES, May 26, 1999, at A1.

313. See A. Leon Higginbotham, Jr., Justice Clarence Thomas in Retrospect, 45 HASTINGS L.J. 1405, 1418 (1994). 
the cases before them. ${ }^{314}$ Life experiences shape the way a person, both consciously and unconsciously, perceives issues presented. They construct frames of reference within which those issues are inevitably placed and that, as a result, affect their resolution. ${ }^{315}$ Competing frames of reference can explain why different decision makers perceive the same legal dispute as implicating very different concerns. There are, moreover, some areas of law, such as environmental law and civil rights law, for which life experiences and related frames of reference appear likely to be more influential. Hence, strong positive or negative life experiences with respect to natural resources can create analogous frames of reference that can result in judges' (and Justices') organizing the facts and legal issues of a case in their minds in a way that highlights the environmental dimension. ${ }^{316}$

What, therefore, are the possible lessons for the future of environmental law in the Supreme Court? They could be to secure, in the first instance, the appointment of Justices on the Supreme Court whose personal and professional life experiences include those that have allowed for a fuller appreciation of the importance and difficulty of the problems environmental law seeks to address. ${ }^{317}$ They might also be to promote such opportunities for current members of the Court.

314. A striking recent example for Justice O'Connor is her joining with the more liberal members of the Court to author the majority opinion in Davis v. Monroe County Board of Education, 119 S. Ct. 1661 (1999), to hold school districts potentially liable under federal civil rights law for sexual harassment of students by other students, notwithstanding O'Connor's normal wariness of federal intrusions on local schools. See id. at 1669-76. In announcing the Court's opinion from the bench, "Justice O'Connor concluded her announcement of the decision by addressing the dissenters who, she said, maintained that the ruling would 'teach little Johnny a perverse lesson in Federalism.' Rather, she said, the majority believed the decision 'assures that little Mary may attend class."' Linda Greenhouse, Sex Harassment in Class Is Ruled Schools' Liability, N.Y. TIMES, May 25, 1999, at A1.

315. See Amos Tversky \& Daniel Kahneman, The Framing of Decisions and the Psychology of Choice, 211 SCIENCE 453 (1981) ("The frame that a decisionmaker adopts is controlled partly by the formulation of the problem and partly by the norms, habirs, and personal characteristics of the decisionmaker. . . [C] hanges of perspective often reverse the relative apparent size of objects and the relative desirability of options.").

316. I owe a special debt here to Professor Chris Schroeder, whose comments on an earlier draft aided me considerably in how to think about this aspect of judicial decision making.

317. The apparent democratization of the process of nominating and confirming Justices to the Supreme Court has made such considerations a topic for public scrutiny in nominees. See SILVERSTEIN, supra note 302, at 160-65. The concerns of environmentalists were among the litany of those raised during Judge Bork's Senate confirmation hearings. See id. at 72.

During the course of the Bork proceedings, for example, the general counsel of the Audubon Society was moved to write the members of the Senate Judiciary Committee and illustrate how Bork's interpretation of the rules of standing and justiciability might seriously constrict the ability of citizen groups to challenge in federal court "the weakening of national surface mining regulations" or to require the government "to issue regulations protecting visibility in our national parks to protect some 
The latter possibility may seem scandalously improper. And undoubtedly any "fact-finding trips" would be, were they designed to influence the Justices' perception of the facts in identifiable cases pending (or soon to be) before the Court. But it seems much less obviously so were the outdoor educational trips planned in conjunction with judicial conferences and more generally aimed at educating judges (including Justices) about the stakes in environmental controversies. ${ }^{318}$ As outrageously unconventional as such a proposal may sound for the promotion of law reform in the Supreme Court, it might nonetheless well be the single most effective means for changing perceptions and attitudes on the Court.

Short of promoting such extracurricular judicial activities, restoration of what is environmental about environmental law will most certainly require more effective advocacy before the Court. Any such advocacy will need to be presented through the legal issues and facts of the individual cases brought to the Court's attention. Each of those cases presents the Justices with a story about the way in which laws affect the quality of life and an opportunity to try to tap into the Justices' own backgrounds in the telling

unique and threatened resources like Mono Lake, the Alaska Coastal Plain or whooping cranes in Central Nebraska."

Id.

Perhaps ironically, however, Judge Bork's subsequent writings strongly suggest that he would have been a strong ally of the environmental community in at least one area-the so-called regulatory takings issue - that is a core legal issue that divides environmental regulators and property rights advocates. See supra notes 255-263 and accompanying text. Judge Bork has specifically denounced the more extreme construction of the Fifth Amendment Just Compensation Clause advanced by property rights advocates as "not plausibly related to the original understanding of the takings clause." See ROBERT H. BORK, THE TEMPTING OF AMERICA: THE POLITICAL SEDUCTION OF THE LAW 230 (1990). To the extent, however, that modern environmental law has been dependent on a vision of an activist government regulating private activity, one would be hard pressed to contend that the environmental community's concerns about Judge Bork were wholly misplaced. But, in all events, what hindsight certainly reveals is that the environmental community was correct that their concerns were substantially implicated by the opening for which Bork was nominated, because Justice Kennedy succeeded to that position on the Court and is today the most telling vote in environmental cases. See supra notes 42-48 and accompanying text. On the other hand, one can question the long-term wisdom of the environmental community's opposition to President Clinton's possible selection of Secretary of the 1nterior Bruce Babbitt as his first nominee to the Supreme Court, based on conservationists' concern with losing him at Interior. See SiLVERSTEIN, supra note 302, at 170; Thomas L. Friedman, The 11th-Hour Scramble: After Hoping for a 'Home Run' in Choosing a Justice, Clinton May Be Just Home Free, N.Y. TIMES, June 15, 1993, at A1.

318. Legislative and executive branch officials, who admittedly have very different policymaking responsibilities and ethical obligations from those of judges, routinely participate in both case-specific and generic fact-finding trips. Although many of these trips are unlikely models for representative democracy, bordering on vacation boondoggles improperly proffered in hope of currying the officials' future favor, there seems to be little question that a fact-finding trip may legitimately provide decision makers with enhanced appreciation of what is at stake in their decision making and, for that reason, promote sounder decisions. 
of that story. The cumulative effect of multiple stories, moreover, can over time significantly affect the way Justices decide what cases to hear and how then to decide the legal issues presented.

The properry rights movement has used this technique with enormous success, but to the detriment of environmental protection concerns. ${ }^{319}$ By bringing to the Justices' attention during the past several decades a series of cases the factual allegations of which appear to support property rights advocates' claims of environmental regulatory overreaching-claims of economic wipeouts, ${ }^{320}$ wheelchair-bound, blind widows being denied the right to build a dream home, ${ }^{321}$ and city planning boards repeatedly breaking promises to developers in a misguided effort to curtail development to protect a butterfly that has not been seen on the land for over a decade ${ }^{322}$-these advocates have successfully fostered a general judicial skepticism about the reasonableness of environmental laws.

The Justices have responded to these stories by repeatedly granting review in cases in the absence of circuit conflict or any other of the indicia traditionally necessary for Supreme Court review. ${ }^{323}$ And, even when it becomes apparent upon closer review that the actual inequities are much

319. Ironically, it is also the members of the property rights movement, not environmentalists, who have recently been accused of literally taking judges on hikes in order to persuade them to be more skeptical of environmental protection laws. Their alleged vehicles for influencing the members of the federal judiciary are legal education programs held for judges in recreational resorts in the Far West. See Douglas T. Kendall \& Charles P. Lord, The Takings Project: A Critical Analysis and Assessment of the Progress So Far, 25 B.C. ENVTL. AFF. L. REV. 509, 511 (1998).

[T] $]$ he most activist judges on the Federal Circuit and the Court of Federal Claimsthe federal courts with exclusive jurisdiction over most takings cases against the federal government-all recently have attended the same, all-expenses-paid, week-long summer seminar at a Montana resort hosted by a property rights group. Finally, we found that the same conservative foundations that funded these Montana seminars also bankroll Id. takings litigation before the Federal Circuit.

320. See, e.g., Lucas v. South Carolina Coastal Council, 505 U.S. 1003, 1014-32 (1992).

321. See Suitum v. Tahoe Reg'l Planning Agency, 520 U.S. 725, 729-33 (1997); Richard J. Lazarus, Litigating Suitum v. Tahoe Regional Planning Agency in the United States Supreme Court, 12 J. LAND USE \& ENVTL. L. 179, 184-86 (1997).

322. See City of Monterey v. Del Monte Dunes at Monterey, Ltd., 119 S. Ct. 1624, 1631 (1999) ("The butterfly lives for one week, travels a maximum of 200 feet, and must land on a mature, flowering buckwheat plant to survive. Searches for the butterfly from 1981 through 1985 yielded but a single larva, discovered in 1984."). It should be noted that the City of Monterey case, unlike the previous regulatory takings cases, was actually brought to the Supreme Court by the city of Monterey and not by the land developer. The city filed the petition for a writ of certiorari in the case, which the Court then granted. See id. at 1635. The Court's opinion on the merits, adverse to the city in many significant respects, exhibits a palatable hostility to the city based on the Court's perception of the inequitable manner in which the city handled the developer's request for permission to develop. The case thereby underscores the pitfalls of unwittingly presenting the Court with "bad facts" for one's own legal position.

323. See Lazarus, supra note 261, at 1415-16. 
smaller than they first appeared, those Justices have strived nonetheless to maintain a majority in favor of the property owner, albeit with a less sweeping ruling than that sought by property rights advocates. The Justices' skepticism towards environmental protection laws and their general view that this is an area of regulatory law that warrants some constitutional curbing has remained intact.

It is, of course, that same judicial skepticism that environmentalists and environmental regulators must now overcome. It will require a concerted effort through case management and case selection to bring to the Justices' attention cases that instruct the Court on the important policies and values safeguarded by environmental protection and natural resource conservation laws. Doing so will, at a minimum, require the discipline necessary to avoid self-inflicted wounds caused by environmentalists and environmental regulators who insist on trying to obtain the Court's review to hear "their case," notwithstanding the poor factual setting within which what might otherwise be a sound legal argument is presented. ${ }^{324}$ Only a persistent, strategic effort can overcome the contrary message successfully communicated to the Justices during the past two decades.

A possible role model is the State and Local Legal Center, which has served an analogous function for state and local governments for more than fifteen years. The center, which is supported by a host of state and local governmental organizations, ${ }^{325}$ was created in response to the widespread concern expressed, including by members of the Court, regarding the relatively poor quality of advocacy before the Court on behalf of the interests of state and local government. ${ }^{326}$

The center, accordingly, assists state and local attorneys in their preparation of briefs and oral arguments before the Court. But, perhaps even more importantly, the center systematically files amicus briefs before the Court in

324. Such a self-inflicted wound appears to have been precisely what occurred in the recent City of Monterey litigation before the Court. See supra note 322. Unfortunately, Justice Kennedy's factual statement in his majority opinion for the Court in that case strongly suggests that the litigation has created even more distance between the environmental movement and the single most important Justice for environmental law before the Court. A far greater self-inflicted wound, however, may have been the opposition that environmentalists directed (apparently successfully) against President Clinton's nominating Secretary of the lnterior Bruce Babbitt to the Supreme Court-the president's reported first choice-because they did not want to lose him at lnterior's helm. See supra note 317.

325. Supporting organizations include, for example, the U.S. Conference of Mayors, the National League of Cities, the Council of State Governments, the National Association of Counties, the International Municipal Lawyers Association, the National Conference of State Legislatures, and the National Governors' Association.

326. See Helping Hand, LEGAL TIMES, Oct. 17, 1983, at 6; Lawrence R. Velvel, "Better Mousetrap" Could Convince High Court, LEGAL TIMES, May 30, 1983, at 10. 
cases raising important legal issues implicating the interests of state and local governments. The briefs are filed by center attorneys who specialize in Supreme Court advocacy and by outside counsel who are experienced Supreme Court practitioners and willing to assist the center on a pro bono basis. The briefs filed express a consistent, coherent, and scholarly vision of the federal-state relationship. They typically take a longer-term, more strategic view regarding how best to influence the Court's decision making, which almost always depends on a series of incremental steps rather than on one paradigm-busting moment. The result has been a most effective presentation to the Court, which has borne much judicial fruit. ${ }^{327}$ That is precisely the kind of effort needed on behalf of environmental protection that has been missing before the Court. ${ }^{328}$

\section{CONCLUSION}

The Supreme Court's attitude towards environmental law during the past three decades has generally been marked by apathy, but with the Justices exhibiting increasing signs of skepticism and some hostility. At best, many of the Justices do not view environmental law as a distinct area of law, but as merely a factual context for the raising of more important crosscutting legal issues. At worst, some of the Justices appear to see the kind of legal regime environmental law promotes as precisely the kind of centralized, intrusive

327. See, e.g., Alden v. Maine, 119 S. Ct. 2240 (1999); College Sav. Bank v. Florida Prepaid Postsecondary Educ. Expense Bd., 119 S. Ct. 2219 (1999); Florida Prepaid Postsecondary Educ. Expense Bd. v. College Sav. Bank, 119 S. Ct. 2199 (1999).

328. The Court's ruling this January in Friends of the Earth, Inc. v. Laidlaw Envtl. Servs. (TOC), Inc., No. 98-822, 2000 U.S. LEXIS 501 (U.S. Jan. 12, 2000), just as this Article went to final press, underscores the advantages of such strategic advocacy. After considerable consultation and debate within the environmental public interest community, the environmental organizations who had lost on standing grounds in both Florida Audubon Society v. Bentsen, 94 F.3d 658 (D.C. Cir. 1996) and Public Interest Research Group v. Magnesium Elektron, Inc., 123 F.3d 111 (3d Cir. 1997) agreed not to petition for certiorari, because of concerns that the facts of those cases did not present those organizations' legal arguments in sufficiently sympathetic factual settings for Supreme Court review. Similar debate preceded the decision to seek certiorari in Friends of the Earth, which had the advantage of both very favorable facts (e.g., trial court findings of hundreds of exceedances of limitations on mercury discharges) and a seasoned Supreme Court advocate (Bruce Terris) representing the environmental petitioner. Counsel for the petitioners consulted with members of the environmental public interest law bar, legal academics, and experienced Supreme Court advocates in preparing the certiorari petition, merits briefs, and oral argument. The amicus briefs were also carefully coordinated and included at least one brief that directly challenged those recent opinions authored by Justice Scalia for the Court that were of greatest concern to environmental citizen suit plaintiffs. See Amicus Brief of Americans for the Environment at 3-10, Friends of the Earth (No. 98-822). The litigation strategy included simultaneous efforts to tell the story of citizen suits to the news media in order to further enhance the prospects of success before the Court, which resulted in a front page story in the New York Times. See William Glaberson, Novel Antipollution Tool Is Being Upset by Courts, N.Y. TIMES, June 5, 1999, at A1. 
system of laws that they believe to be both constitutionally suspect and unwise as a matter of social policy.

It will not be easy to change the views of the current Justices or to secure the future appointment of Justices who feel different about environmental law. Like environmental law itself, the undertaking will be long-term and inevitably marked by short-term missteps. It will require a persistent, case-bycase effort to present environmental law's story to the Justices in factual settings that bolster rather than undermine the importance of environmental protection. The purpose of such advocacy should be for the Justices to gain a broader understanding of the particular challenges presented by the establishment of a legal regime for environmental protection and then to be willing to meet those challenges. Only then can the puzzling role that the Court has played in environmental law during the past three decades come to an end and the Justices' current skepticism be replaced by their active and constructive engagement. 


\section{APPENDIX A}

Environmental Cases Decided by the United States Supreme Court October Term 1969-October Term 1998

\begin{tabular}{|c|c|c|}
\hline$\underline{\text { Cite }}$ & $\underline{\text { Name }}$ & 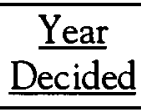 \\
\hline 397 U.S. 88 & Arkansas v. Tennessee & 1970 \\
\hline 397 U.S. 620 & Choctaw Nation v. Oklahoma & 1970 \\
\hline 400 U.S. 48 & Hickel v. Oil Shale Corp. & 1970 \\
\hline 401 U.S. 402 & $\begin{array}{c}\text { Citizens to Preserve Overton Park, Inc. } v . \\
\text { Volpe }\end{array}$ & 1971 \\
\hline 401 U.S. 493 & Ohio v. Wyandotte Chemicals Corp. & 1971 \\
\hline 401 U.S. 520 & United States v. District Court & 1971 \\
\hline 401 U.S. 527 & $\begin{array}{l}\text { United States } v . \text { District Court in and for Water } \\
\text { Division No. } 5\end{array}$ & 1971 \\
\hline 402 U.S. 159 & $\begin{array}{c}\text { United States } v . \text { Southern Ute Tribe or Band of } \\
\text { Indians }\end{array}$ & 1971 \\
\hline 402 U.S. 558 & $\begin{array}{l}\text { United States } v \text {. International Minerals } \mathcal{E} \\
\text { Chemical Corp. }\end{array}$ & 1971 \\
\hline 403 U.S. 9 & Utah $v$. United States & 1971 \\
\hline 405 U.S. 727 & Sierra Club v. Morton & 1972 \\
\hline 406 U.S. 91 & Illinois $थ$. City of Milwaukee & 1972 \\
\hline 406 U.S. 109 & Washington v. General Motors Corp. & 1972 \\
\hline 406 U.S. 117 & Nebraska थ. Iowa & 1972 \\
\hline 409 U.S. 80 & United States $v$. Jim & 1972 \\
\hline 409 U.S. 470 & $\begin{array}{c}\text { Almota Farmers Elevator \& Warehouse Co. } v . \\
\text { United States }\end{array}$ & 1973 \\
\hline 410 U.S. 73 & EPA थ. Mink & 1973 \\
\hline 410 U.S. 641 & Ohio v. Kentucky & 1973 \\
\hline 410 U.S. 719 & $\begin{array}{c}\text { Salyer Land Co. v. Tulare Lake Basin Water } \\
\text { Storage District }\end{array}$ & 1973 \\
\hline 410 U.S. 743 & $\begin{array}{l}\text { Associated Enterprises, Inc. } v \text {. Toltec } \\
\text { Watershed Improvement District }\end{array}$ & 1973 \\
\hline
\end{tabular}




\begin{tabular}{|c|c|c|}
\hline$\underline{\text { Cite }}$ & $\underline{\text { Name }}$ & 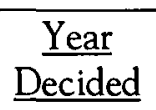 \\
\hline 411 U.S. 325 & Askew v. American Waterways Operators, Inc. & 1973 \\
\hline 411 U.S. 624 & City of Burbank v. Lockheed Air Terminal, Inc. & 1973 \\
\hline 411 U.S. 655 & $\begin{array}{l}\text { United States v. Pennsylvania Industrial } \\
\text { Chemical Corp. }\end{array}$ & 1973 \\
\hline 412 U.S. 481 & Mattz v. Amett & 1973 \\
\hline 412 U.S. 541 & Fri v. Sierra Club & 1973 \\
\hline 412 U.S. 580 & United States v. Little Lake Misere Land Co. & 1973 \\
\hline 412 U.S. 669 & $\begin{array}{l}\text { United States } v . \text { Students Challenging } \\
\text { Regulatory Agency Procedures (SCRAP) }\end{array}$ & 1973 \\
\hline 414 U.S. 44 & Department of Game v. Puyallup Tribe & 1973 \\
\hline 414 U.S. 313 & Bonelli Cattle Co. ข. Arizona & 1973 \\
\hline 415 U.S. 289 & Mississippi v. Arkansas & 1974 \\
\hline 416 U.S. 1 & Village of Belle Terre v. Boraas & 1974 \\
\hline 416 U.S. 861 & $\begin{array}{l}\text { Air Pollution Variance Board } v \text {. Western Alfalfa } \\
\text { Corp. }\end{array}$ & 1974 \\
\hline 420 U.S. 35 & Train $v$. City of New York & 1975 \\
\hline 420 U.S. 136 & Train v. Campaign Clean Water, Inc. & 1975 \\
\hline 420 U.S. 194 & Antoine $v$. Washington & 1975 \\
\hline 420 U.S. 304 & Utah $v$. United States & 1975 \\
\hline 420 U.S. 395 & $\begin{array}{l}\text { Chemehuevi Tribe of Indians v. Federal Power } \\
\text { Commission }\end{array}$ & 1975 \\
\hline 420 U.S. 515 & United States v. Maine & 1975 \\
\hline 420 U.S. 529 & United States $v$. Louisiana & 1975 \\
\hline 420 U.S. 531 & United States $v$. Florida & 1975 \\
\hline 421 U.S. 60 & $\begin{array}{l}\text { Train v. Natural Resources Defense Council, } \\
\text { Inc. }\end{array}$ & 1975 \\
\hline 421 U.S. 240 & $\begin{array}{c}\text { Alyeska Pipeline Service Co. v. Wilderness } \\
\text { Society }\end{array}$ & 1975 \\
\hline 422 U.S. 13 & United States $v$. Louisiana & 1975 \\
\hline 422 U.S. 184 & United States v. Alaska & 1975 \\
\hline
\end{tabular}




\begin{tabular}{|c|c|c|}
\hline$\underline{\text { Cite }}$ & $\underline{\text { Name }}$ & $\begin{array}{l}\text { Year } \\
\text { Decided }\end{array}$ \\
\hline 422 U.S. 289 & $\begin{array}{c}\text { Aberdeen } \mathcal{E} \text { Rockfish Railroad Co. v. Students } \\
\text { Challenging Regulatory Agency Procedures } \\
\text { (SCRAP) }\end{array}$ & 1975 \\
\hline 424 U.S. 295 & Alamo Land \& Cattle Co. v. Arizona & 1976 \\
\hline 425 U.S. 649 & Northern Cheyenne Tribe v. Hollowbreast & 1976 \\
\hline 426 U.S. 1 & $\begin{array}{c}\text { Train v. Colorado Public Interest Research } \\
\text { Group, Inc. }\end{array}$ & 1976 \\
\hline 426 U.S. 128 & Cappaert $v$. United States & 1976 \\
\hline 426 U.S. 167 & Hancock ข. Train & 1976 \\
\hline 426 U.S. 200 & $\begin{array}{c}\text { EPA v. California ex rel. State Water Resources } \\
\text { Control Board }\end{array}$ & 1976 \\
\hline 426 U.S. 363 & New Hampshire v. Maine & 1976 \\
\hline 426 U.S. 465 & Texas ข. Louisiana & 1976 \\
\hline 426 U.S. 529 & Kleppe v. New Mexico & 1976 \\
\hline 426 U.S. 776 & $\begin{array}{c}\text { Flint Ridge Development Co. v. Scenic Rivers } \\
\text { Ass'n }\end{array}$ & 1976 \\
\hline 427 U.S. 246 & Union Electric Co. v. EPA & 1976 \\
\hline 427 U.S. 390 & Kleppe v. Sierra Club & 1976 \\
\hline 429 U.S. 363 & $\begin{array}{l}\text { Oregon ex rel. State Land Board थ. Corvallis } \\
\text { Sand \& Gravel Co. }\end{array}$ & 1977 \\
\hline 430 U.S. 112 & E.I. duPont de Nemours $\mathcal{E}$ Co. v. Train & 1977 \\
\hline 431 U.S. 99 & EPA v. Brown & 1977 \\
\hline 431 U.S. 265 & Douglas v. Seacoast Products, Inc. & 1977 \\
\hline 434 U.S. 275 & Adamo Wrecking Co. v. United States & 1978 \\
\hline 435 U.S. 151 & Ray v. Atlantic Richfield Co. & 1978 \\
\hline 435 U.S. 519 & $\begin{array}{l}\text { Vermont Yankee Nuclear Power Corp. v. } \\
\text { National Resources Defense Council, Inc. }\end{array}$ & 1978 \\
\hline 436 U.S. 371 & Baldwin v. Fish \& Game Commission & 1978 \\
\hline 436 U.S. 604 & Andrus v. Charlestone Stone Products Co. & 1978 \\
\hline 437 U.S. 153 & Tennessee Valley Authority v. Hill & 1978 \\
\hline 437 U.S. 617 & City of Philadelphia v. New Jersey & 1978 \\
\hline
\end{tabular}




\begin{tabular}{|c|c|c|}
\hline$\underline{\text { Cite }}$ & $\underline{\text { Name }}$ & $\underline{\text { Year }}$ \\
\hline 438 U.S. 59 & $\begin{array}{c}\text { Duke Power Co. v. Carolina Environmental } \\
\text { Study Group, Inc. }\end{array}$ & 1978 \\
\hline 438 U.S. 104 & $\begin{array}{c}\text { Penn Central Transportation Co. v. New York } \\
\text { City }\end{array}$ & 1978 \\
\hline 438 U.S. 645 & California v. United States & 1978 \\
\hline 438 U.S. 696 & United States v. New Mexico & 1978 \\
\hline 440 U.S. 391 & $\begin{array}{l}\text { Lake Country Estates, Inc. v. Tahoe Regional } \\
\text { Planning Agency }\end{array}$ & 1979 \\
\hline 440 U.S. 668 & Leo Sheep Co. v. United States & 1979 \\
\hline 441 U.S. 322 & Hughes v. Oklahoma & 1979 \\
\hline 442 U.S. 347 & Andrus v. Sierra Club & 1979 \\
\hline 442 U.S. 653 & Wilson थ. Omaha Indian Tribe & 1979 \\
\hline 443 U.S. 658 & $\begin{array}{c}\text { Washington थ. Washington State Commercial } \\
\text { Passenger Fishing Vessel Ass'n }\end{array}$ & 1979 \\
\hline 444 U.S. 51 & Andrus v. Allard & 1979 \\
\hline 444 U.S. 164 & Kaiser Aetna v. United States & 1979 \\
\hline 444 U.S. 206 & Vaughn थ. Vermilion Corp. & 1979 \\
\hline 444 U.S. 223 & $\begin{array}{l}\text { Strycker's Bay Neighborhood Council, Inc. } v . \\
\text { Karlen }\end{array}$ & 1980 \\
\hline 444 U.S. 335 & Ohio v. Kentucky & 1980 \\
\hline 445 U.S. 193 & Crown Simpson Pulp Co. v. Costle & 1980 \\
\hline 445 U.S. 198 & Costle v. Pacific Legal Foundation & 1980 \\
\hline 445 U.S. 253 & United States $v$. Clarke & 1980 \\
\hline 445 U.S. 535 & United States v. Mitchell & 1980 \\
\hline 445 U.S. 715 & Andrus v. Idaho & 1980 \\
\hline 446 U.S. 253 & United States ข. Louisiana & 1980 \\
\hline 446 U.S. 500 & Andrus थ. Utah & 1980 \\
\hline 446 U.S. 578 & Harrison v. PPG Industries, Inc. & 1980 \\
\hline 446 U.S. 657 & Andrus v. Shell Oil Co. & 1980 \\
\hline 447 U.S. 1 & United States $v$. California & 1980 \\
\hline 447 U.S. 125 & California ข. Nevada & 1980 \\
\hline
\end{tabular}




\begin{tabular}{|c|c|c|}
\hline$\underline{\text { Cite }}$ & $\underline{\text { Name }}$ & 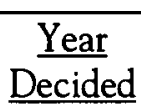 \\
\hline 447 U.S. 255 & Agins v. City of Tiburon & 1980 \\
\hline 447 U.S. 352 & Bryant v. Yellen & 1980 \\
\hline 448 U.S. 242 & United States $v$. Ward & 1980 \\
\hline 448 U.S. 371 & United States $v$. Sioux Nation of Indians & 1980 \\
\hline 448 U.S. 607 & $\begin{array}{c}\text { Industrial Union Department v. American } \\
\text { Petroleum Institute }\end{array}$ & 1980 \\
\hline 449 U.S. 64 & EPA v. National Crushed Stone Ass'n & 1980 \\
\hline 449 U.S. 456 & Minnesota v. Clover Leaf Creamery Co. & 1981 \\
\hline 450 U.S. 544 & Montana v. United States & 1981 \\
\hline 450 U.S. 621 & $\begin{array}{c}\text { San Diego Gas } \mathcal{E} \text { Electric Co. v. City of San } \\
\text { Diego }\end{array}$ & 1981 \\
\hline 451 U.S. 259 & Watt v. Alaska & 1981 \\
\hline 451 U.S. 287 & California v. Sierra Club & 1981 \\
\hline 452 U.S. 264 & $\begin{array}{l}\text { Hodel v. Virginia Surface Mining } \mathcal{E} \\
\text { Reclamation Ass'n }\end{array}$ & 1981 \\
\hline 452 U.S. 314 & Hodel v. Indiana & 1981 \\
\hline 453 U.S. 1 & $\begin{array}{l}\text { Middlesex County Sewerage Authority v. } \\
\text { National Sea Clammers Ass' } n\end{array}$ & 1981 \\
\hline 453 U.S. 490 & Metromedia, Inc. v. City of San Diego & 1981 \\
\hline 453 U.S. 609 & Commonwealth Edison Co. v. Montana & 1981 \\
\hline 454 U.S. 139 & $\begin{array}{c}\text { Weinberger v. Catholic Action of Hawaii/Peace } \\
\text { Education Project }\end{array}$ & 1981 \\
\hline 454 U.S. 151 & Watt v. Energy Action Educational Foundation & 1981 \\
\hline 454 U.S. 516 & Texaco, Inc. v. Short & 1982 \\
\hline 456 U.S. 305 & Weinberger v. Romero-Barcelo & 1982 \\
\hline 457 U.S. 55 & Zobel v. Williams & 1982 \\
\hline 457 U.S. 273 & $\begin{array}{c}\text { Califormia ex rel. State Lands Commission v. } \\
\text { United States }\end{array}$ & 1982 \\
\hline 458 U.S. 941 & Sporhase v. Nebraska ex rel. Douglas & 1982 \\
\hline 459 U.S. 176 & Colorado v. New Mexico & 1982 \\
\hline 460 U.S. 300 & North Dakota v. United States & 1983 \\
\hline 460 U.S. 605 & Arizona v. California & 1983 \\
\hline
\end{tabular}




\begin{tabular}{|c|c|c|}
\hline$\underline{\text { Cite }}$ & $\underline{\text { Name }}$ & $\begin{array}{l}\text { Year } \\
\text { Decided }\end{array}$ \\
\hline 460 U.S. 766 & $\begin{array}{c}\text { Metropolitan Edison Co. v. People Against } \\
\text { Nuclear Energy }\end{array}$ & 1983 \\
\hline 461 U.S. 190 & $\begin{array}{c}\text { Pacific Gas \& Electric Co. } v \text {. State Energy } \\
\text { Resources Conservation \& Development } \\
\text { Commission }\end{array}$ & 1983 \\
\hline 461 U.S. 273 & $\begin{array}{c}\text { Block v. North Dakota ex rel. Board of } \\
\text { University \& School Lands }\end{array}$ & 1983 \\
\hline 462 U.S. 36 & Watt v. Western Nuclear, Inc. & 1983 \\
\hline 462 U.S. 87 & $\begin{array}{l}\text { Baltimore Gas } \mathscr{E} \text { Electric Co. v. Natural } \\
\text { Resources Defense Council, Inc. }\end{array}$ & 1983 \\
\hline 462 U.S. 554 & Texas v. New Mexico & 1983 \\
\hline $\begin{array}{c}462 \text { U.S. } \\
1017\end{array}$ & Idaho ex rel. Evans v. Oregon & 1983 \\
\hline 463 U.S. 110 & Nevada v. United States & 1983 \\
\hline 463 U.S. 206 & United States $v$. Mitchell & 1983 \\
\hline 463 U.S. 545 & Arizona v. San Carlos Apache Tribe & 1983 \\
\hline 464 U.S. 238 & Silkwood v. Kerr-McGee Corp. & 1984 \\
\hline 464 U.S. 312 & Secretary of the Interior v. Califormia & 1984 \\
\hline 466 U.S. 96 & Louisiana v. Mississippi & 1984 \\
\hline 466 U.S. 198 & $\begin{array}{c}\text { Summa Corp. v. California ex rel. State Lands } \\
\text { Commission }\end{array}$ & 1984 \\
\hline 466 U.S. 765 & $\begin{array}{c}\text { Escondido Mutual Water Co. v. La Jolla Band } \\
\text { of Mission Indians }\end{array}$ & 1984 \\
\hline 467 U.S. 1 & Kirby Forest Industries, Inc. v. United States & 1984 \\
\hline 467 U.S. 229 & Hawaii Housing Authority v. Midkiff & 1984 \\
\hline 467 U.S. 310 & Colorado v. New Mexico & 1984 \\
\hline 467 U.S. 837 & $\begin{array}{c}\text { Chevron U.S.A. Inc. v. Natural Resources } \\
\text { Defense Council, Inc. }\end{array}$ & 1984 \\
\hline 467 U.S. 986 & Ruckelshaus v. Monsanto Co. & 1984 \\
\hline 469 U.S. 274 & Ohio v. Kovacs & 1985 \\
\hline 469 U.S. 504 & United States $v$. Maine & 1985 \\
\hline 470 U.S. 93 & United States $v$. Louisiana & 1985 \\
\hline
\end{tabular}




\begin{tabular}{|c|c|c|}
\hline$\underline{\text { Cite }}$ & $\underline{\text { Name }}$ & $\underline{\text { Year }}$ Decided \\
\hline 470 U.S. 116 & $\begin{array}{l}\text { Chemical Manufacturers Ass'n v. Natural } \\
\text { Resources Defense Council, Inc. }\end{array}$ & 1985 \\
\hline 471 U.S. 84 & United States $v$. Locke & 1985 \\
\hline 471 U.S. 759 & Montana $v$. Blackfeet Tribe of Indians & 1985 \\
\hline 473 U.S. 172 & $\begin{array}{l}\text { Williamson County Regional Planning } \\
\text { Commission v. Hamilton Bank }\end{array}$ & 1985 \\
\hline 473 U.S. 568 & $\begin{array}{l}\text { Thomas v. Union Carbide Agricultural Products } \\
\text { Co. }\end{array}$ & 1985 \\
\hline 473 U.S. 753 & $\begin{array}{l}\text { Oregon Department of Fish } \mathscr{E} \text { Wildlife v. } \\
\text { Klamath Indian Tribe }\end{array}$ & 1985 \\
\hline 474 U.S. 121 & United States $थ$. Riverside Bayview Homes, Inc. & 1985 \\
\hline 474 U.S. 494 & $\begin{array}{l}\text { Midlantic National Bank v. New Jersey } \\
\text { Department of Environmental Protection }\end{array}$ & 1986 \\
\hline 475 U.S. 1 & $\begin{array}{l}\text { Pacific Gas \& Electric Co. v. Public Utilities } \\
\text { Commission }\end{array}$ & 1986 \\
\hline 475 U.S. 89 & United States v. Maine & 1986 \\
\hline 475 U.S. 355 & Exxon Corp. v. Hunt & 1986 \\
\hline 476 U.S. 227 & Dow Chemical Co. $v$. United States & 1986 \\
\hline 476 U.S. 498 & South Carolina v. Catawba Indian Tribe, Inc. & 1986 \\
\hline 476 U.S. 834 & United States v. Mottaz & 1986 \\
\hline 477 U.S. 131 & Maine ข. Taylor & 1986 \\
\hline 477 U.S. 207 & Offshore Logistics, Inc. $v$. Tallentire & 1986 \\
\hline 477 U.S. 340 & $\begin{array}{c}\text { MacDonald, Sommer } \mathcal{G} \text { Frates v. County of } \\
\text { Yolo }\end{array}$ & 1986 \\
\hline 478 U.S. 221 & $\begin{array}{c}\text { Japan Whaling Ass'n } v \text {. American Cetacean } \\
\text { Society }\end{array}$ & 1986 \\
\hline 478 U.S. 546 & $\begin{array}{l}\text { Pennsylvania थ. Delaware Valley Citizens' } \\
\text { Council for Clean Air }\end{array}$ & 1986 \\
\hline 478 U.S. 597 & United States v. James & 1986 \\
\hline 479 U.S. 481 & International Paper Co. v. Ouellette & 1987 \\
\hline 480 U.S. 370 & Stringfellow v. Concerned Neighbors in Action & 1987 \\
\hline
\end{tabular}




\begin{tabular}{|c|c|c|}
\hline$\underline{\text { Cite }}$ & $\underline{\text { Name }}$ & 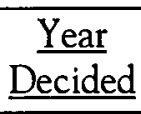 \\
\hline 480 U.S. 470 & $\begin{array}{l}\text { Keystone Bituminous Coal Ass'n v. } \\
\text { DeBenedictis }\end{array}$ & 1987 \\
\hline 480 U.S. 531 & Amoco Production Co. v. Village of Gambell & 1987 \\
\hline 480 U.S. 572 & $\begin{array}{l}\text { California Coastal Commission v. Granite Rock } \\
\text { Co. }\end{array}$ & 1987 \\
\hline 480 U.S. 700 & United States $v$. Cherokee Nation & 1987 \\
\hline 481 U.S. 412 & Tull $v$. United States & 1987 \\
\hline 481 U.S. 704 & Hodel v. Irving & 1987 \\
\hline 482 U.S. 124 & Texas थ. New Mexico & 1987 \\
\hline 482 U.S. 193 & Utah Division of State Lands v. United States & 1987 \\
\hline 482 U.S. 304 & $\begin{array}{l}\text { First English Evangelical Lutheran Church v. } \\
\text { County of Los Angeles }\end{array}$ & 1987 \\
\hline 483 U.S. 711 & $\begin{array}{c}\text { Pennsylvania v. Delaware Valley Citizens' } \\
\text { Council for Clean Air }\end{array}$ & 1987 \\
\hline 483 U.S. 825 & Nollan v. Califormia Coastal Commission & 1987 \\
\hline 484 U.S. 49 & $\begin{array}{l}\text { Gwaltney of Smithfield, Ltd. v. Chesapeake Bay } \\
\text { Foundation, Inc. }\end{array}$ & 1987 \\
\hline 484 U.S. 469 & Phillips Petroleum Co. v. Mississippi & 1988 \\
\hline 484 U.S. 495 & ETSI Pipeline Project v. Missouri & 1988 \\
\hline 485 U.S. 88 & United States v. Louisiana & 1988 \\
\hline 485 U.S. 439 & $\begin{array}{l}\text { Lyng v. Northwest Indian Cemetery Protective } \\
\text { Ass'n }\end{array}$ & 1988 \\
\hline 490 U.S. 163 & Cotton Petroleum Corp. v. New Mexico & 1989 \\
\hline 490 U.S. 332 & Robertson v. Methow Valley Citizens Council & 1989 \\
\hline 490 U.S. 360 & Marsh v. Oregon Natural Resources Council & 1989 \\
\hline 491 U.S. 1 & Pennsyluania v. Union Gas Co. & 1989 \\
\hline 491 U.S. 350 & $\begin{array}{l}\text { New Orleans Public Service, Inc. v. Council of } \\
\text { New Orleans }\end{array}$ & 1989 \\
\hline 492 U.S. 408 & $\begin{array}{l}\text { Brendale v. Confederated Tribes \& Bands of the } \\
\text { Yakima Indian Nation }\end{array}$ & 1989 \\
\hline 493 U.S. 20 & Hallstrom v. Tillamook County & 1989 \\
\hline
\end{tabular}




\begin{tabular}{|c|c|c|}
\hline$\underline{\text { Cite }}$ & $\underline{\text { Name }}$ & $\underline{\text { Year }}$ \\
\hline 495 U.S. 490 & $\begin{array}{l}\text { California v. Federal Energy Regulatory } \\
\text { Commission }\end{array}$ & 1990 \\
\hline 496 U.S. 530 & General Motors Corp. ข. United States & 1990 \\
\hline 497 U.S. 871 & Lujan थ. National Wildlife Federation & 1990 \\
\hline 500 U.S. 380 & Illinois $v$. Kentucky & 1991 \\
\hline 501 U.S. 221 & Oklahoma v. New Mexico & 1991 \\
\hline 501 U.S. 597 & Wisconsin Public Intervenor v. Mortier & 1991 \\
\hline 502 U.S. 437 & Wyoming v. Oklahoma & 1992 \\
\hline 503 U.S. 91 & Arkansas v. Oklahoma & 1992 \\
\hline 503 U.S. 429 & Robertson v. Seattle Audubon Society & 1992 \\
\hline 503 U.S. 519 & Yee v. City of Escondido & 1992 \\
\hline 503 U.S. 569 & United States v. Alaska & 1992 \\
\hline 503 U.S. 607 & United States Department of Energy ข. Ohio & 1992 \\
\hline 504 U.S. 334 & Chemical Waste Management, Inc. v. Hunt & 1992 \\
\hline 504 U.S. 353 & $\begin{array}{c}\text { Fort Gratiot Sanitary Landfill, Inc. v. Michigan } \\
\text { Department of Natural Resources }\end{array}$ & 1992 \\
\hline 504 U.S. 555 & Lujan $v$. Defenders of Wildlife & 1992 \\
\hline 505 U.S. 88 & $\begin{array}{l}\text { Gade v. National Solid Wastes Management } \\
\text { Ass'n }\end{array}$ & 1992 \\
\hline 505 U.S. 144 & New York v. United States & 1992 \\
\hline 505 U.S. 557 & City of Burlington v. Dague & 1992 \\
\hline $\begin{array}{c}505 \text { U.S. } \\
1003\end{array}$ & Lucas v. South Carolina Coastal Council & 1992 \\
\hline 506 U.S. 73 & Mississippi v. Louisiana & 1992 \\
\hline 507 U.S. 584 & Nebraska v. Wyoming & 1993 \\
\hline 508 U.S. 679 & South Dakota v. Bourland & 1993 \\
\hline 511 U.S. 93 & $\begin{array}{c}\text { Oregon Waste Systems, Inc. v. Department of } \\
\text { Environmental Quality }\end{array}$ & 1994 \\
\hline 511 U.S. 328 & City of Chicago v. Environmental Defense Fund & 1994 \\
\hline 511 U.S. 383 & CËA Carbone, Inc. v. Toum of Clarkstown & 1994 \\
\hline
\end{tabular}




\begin{tabular}{|c|c|c|}
\hline$\underline{\text { Cite }}$ & $\underline{\text { Name }}$ & $\begin{array}{l}\text { Year } \\
\text { Decided }\end{array}$ \\
\hline 511 U.S. 700 & $\begin{array}{l}\text { PUD No. } 1 \text { v. Washington Department of } \\
\text { Ecology }\end{array}$ & 1994 \\
\hline 511 U.S. 809 & Key Tronic Corp. $v$. United States & 1994 \\
\hline 512 U.S. 43 & City of Ladue v. Gilleo & 1994 \\
\hline 512 U.S. 374 & Dolan v. City of Tigard & 1994 \\
\hline 513 U.S. 527 & $\begin{array}{c}\text { Jerome B. Grubart, Inc. v. Great Lakes Dredge } \\
\text { E Dock Co. }\end{array}$ & 1995 \\
\hline 514 U.S. 673 & Kansas v. Colorado & 1995 \\
\hline 515 U.S. 1 & Nebraska v. Wyoming & 1995 \\
\hline 515 U.S. 687 & $\begin{array}{l}\text { Babbitt v. Sweet Home Chapter of Communities } \\
\text { for a Great Oregon }\end{array}$ & 1995 \\
\hline 516 U.S. 22 & Louisiana ข. Mississippi & 1995 \\
\hline 516 U.S. 365 & United States $v$. Maine & 1996 \\
\hline 516 U.S. 479 & Meghrig v. KFC Western, Inc. & 1996 \\
\hline 519 U.S. 234 & Babbitt v. Youpee & 1997 \\
\hline 519 U.S. 355 & Bibles v. Oregon Natural Desert Ass'n & 1997 \\
\hline 520 U.S. 154 & Bennett $v$. Spear & 1997 \\
\hline 520 U.S. 725 & Suitum ข. Tahoe Regional Planning Agency & 1997 \\
\hline 521 U.S. 1 & United States ข. Alaska & 1997 \\
\hline 521 U.S. 261 & Idaho v. Coeur d'Alene Tribe & 1997 \\
\hline 521 U.S. 507 & City of Boerne v. Flores & 1997 \\
\hline 521 U.S. 591 & Amchem Products, Inc. v. Windsor & 1997 \\
\hline 522 U.S. 329 & South Dakota v. Yankton Sioux Tribe & 1998 \\
\hline 522 U.S. 520 & $\begin{array}{c}\text { Alaska v. Native Village of Venetie Tribal } \\
\text { Government }\end{array}$ & 1998 \\
\hline 523 U.S. 83 & Steel Co. v. Citizens for a Better Environment & 1998 \\
\hline 523 U.S. 726 & Ohio Forestry Ass'n v. Sierra Club & 1998 \\
\hline 523 U.S. 767 & New Jersey थ. New York & 1998 \\
\hline 524 U.S. 38 & United States v. Beggerly & 1998 \\
\hline 524 U.S. 51 & United States v. Bestfoods & 1998 \\
\hline
\end{tabular}




\begin{tabular}{|c|c|c|}
\hline Cite & Name & $\begin{array}{c}\text { Year } \\
\text { Decided }\end{array}$ \\
\hline $\begin{array}{c}\text { 119 S. Ct. } \\
1624\end{array}$ & $\begin{array}{c}\text { City of Monterey v. Del Monte Dunes at } \\
\text { Monterey, Ltd. }\end{array}$ & 1999 \\
\hline $\begin{array}{c}\text { 119 S. Ct. } \\
\text { 1719 }\end{array}$ & $\begin{array}{c}\text { Amoco Production Co. v. Southern Ute Indian } \\
\text { Tribe }\end{array}$ & 1999 \\
\hline
\end{tabular}




\section{APPENDIX B}

Environmental Cases Decided by the United States Supreme Court October Term 1969-October Term 1998

By Justice-Number of Opinions Authored and Majority Opinions Joined

\begin{tabular}{|c|c|c|c|c|c|}
\hline Justice & $\underline{\text { Opinion }}$ & $\underline{\text { Majority }}$ & $\underline{\text { Dissent }}$ & $\frac{\text { Percent in }}{\text { Majority }}$ & $\frac{\underline{\text { Majorityl }}}{\frac{\text { Dissent }}{\text { Split }}}$ \\
\hline Black & 0 & 6 & 2 & 75.00 percent & 0 \\
\hline Blackmun & 22 & 160 & 40 & 80.00 percent & 1 \\
\hline Brennan & 16 & 141 & 38 & 78.77 percent & 2 \\
\hline Breyer & 1 & 20 & 3 & 86.96 percent & 0 \\
\hline Burger & 8 & 140 & 13 & 91.50 percent & 2 \\
\hline Douglas & 12 & 20 & 11 & 64.52 percent & 1 \\
\hline Ginsburg & 2 & 29 & 3 & 90.63 percent & 0 \\
\hline Harlan & 1 & 6 & 1 & 85.71 percent & 0 \\
\hline Kennedy & 6 & 55 & 2 & 96.49 percent & 1 \\
\hline Marshall & 20 & 139 & 37 & 78.98 percent & 3 \\
\hline O'Connor & 21 & 109 & 17 & 86.51 percent & 2 \\
\hline Powell & 10 & 124 & 19 & 86.71 percent & 2 \\
\hline Rehnquist & 21 & 175 & 34 & 83.73 percent & 5 \\
\hline Scalia & 9 & 64 & 12 & 84.21 percent & 1 \\
\hline Souter & 7 & 42 & 7 & 85.71 percent & 0 \\
\hline
\end{tabular}




\begin{tabular}{|c|c|c|c|c|c|}
\hline Lustice & $\begin{array}{l}\text { Opinion } \\
\text { Author }\end{array}$ & Majority & Dissent & $\frac{\text { Percent in }}{\text { Majority }}$ & $\begin{array}{c}\frac{\text { Majority/ }}{\text { Dissent }} \\
\text { Split }\end{array}$ \\
\hline Stevens & 21 & 142 & 44 & 76.34 percent & 1 \\
\hline Stewart & 7 & 86 & 15 & 85.15 percent & 0 \\
\hline Thomas & 4 & 39 & 6 & 86.67 percent & 1 \\
\hline White & 36 & 173 & 21 & 89.18 percent & 2 \\
\hline
\end{tabular}




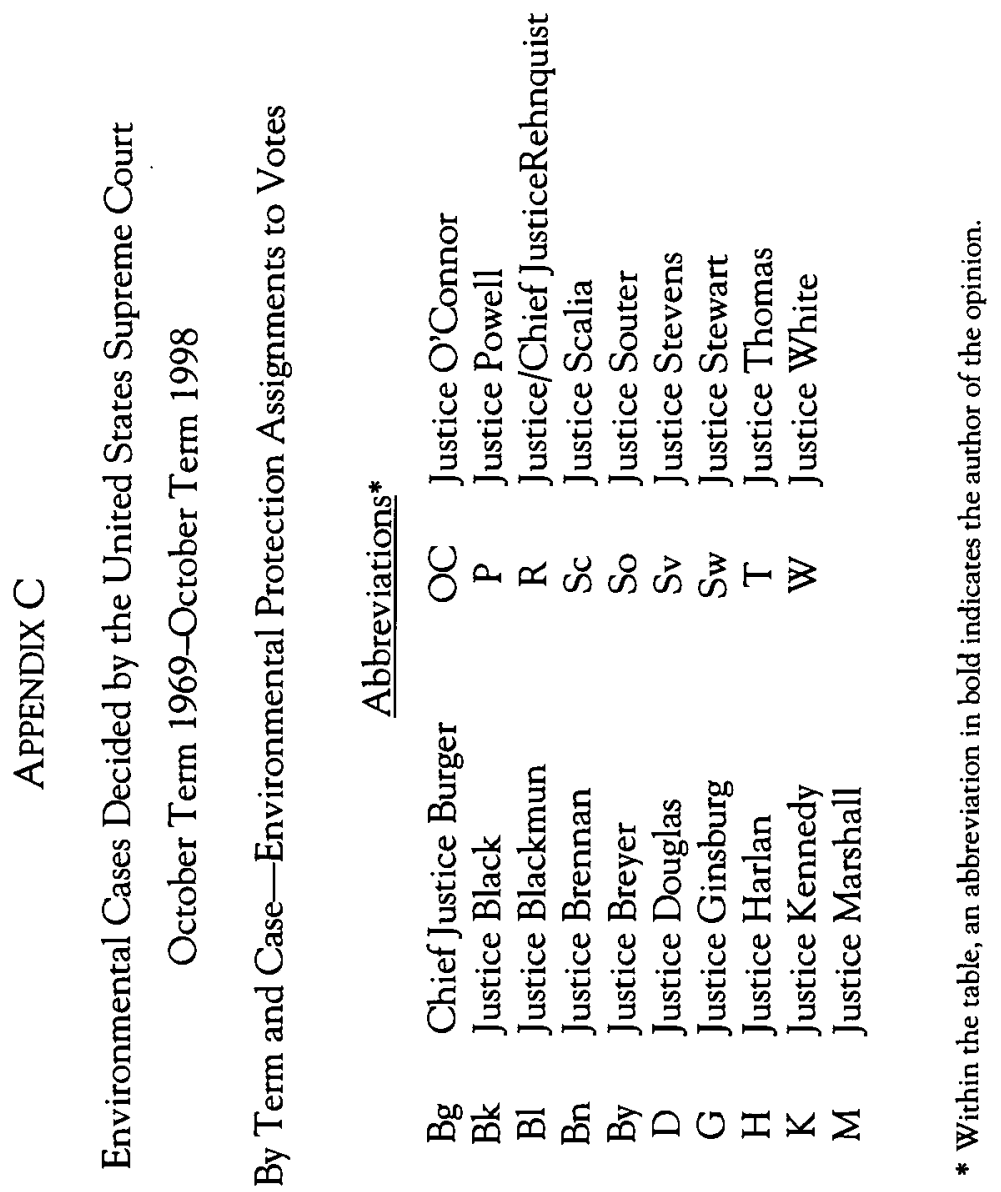




\begin{tabular}{|c|c|c|c|c|c|}
\hline نั & & $\bar{\Omega}$ & & & \\
\hline 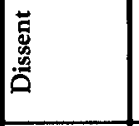 & $\begin{array}{l}\infty \\
\stackrel{\infty}{n} \\
\tilde{n}\end{array}$ & 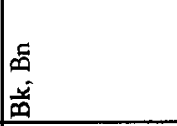 & $\Omega$ & 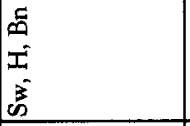 & 0 品 $\overline{\mathbf{m}}$ \\
\hline 竞 & 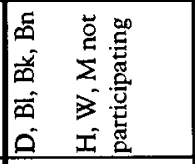 & 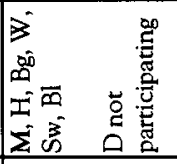 & 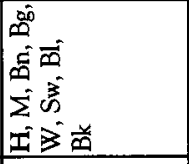 & 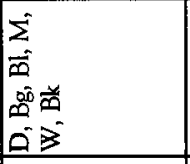 & 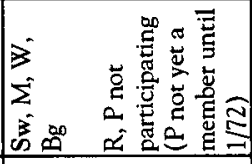 \\
\hline 守 & 焉 & 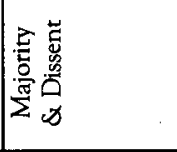 & 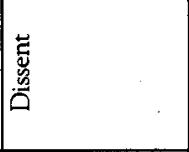 & $\mid \frac{3}{5}$ & 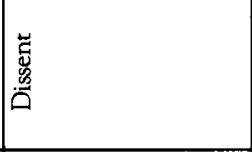 \\
\hline Ð & 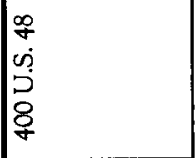 & 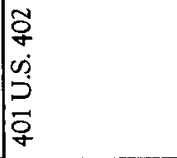 & $\mid \begin{array}{l}\tilde{a} \\
\dot{\alpha} \\
\vdots \\
\vdots \\
\bar{q}\end{array}$ & 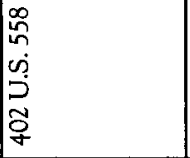 & 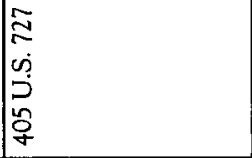 \\
\hline 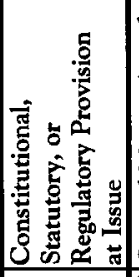 & 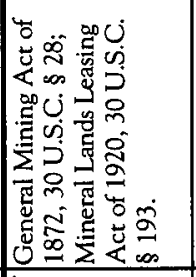 & 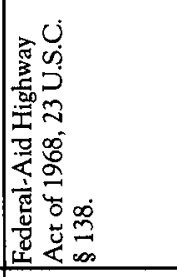 & 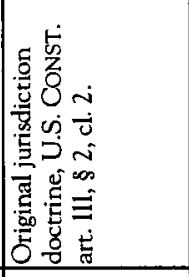 & 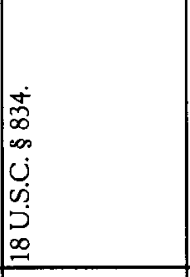 & 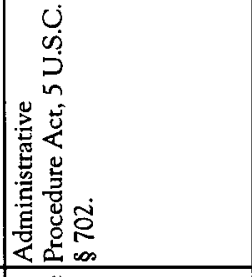 \\
\hline 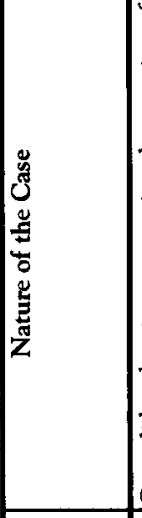 & 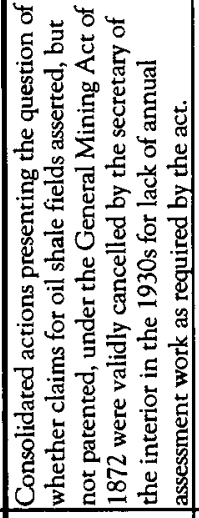 & 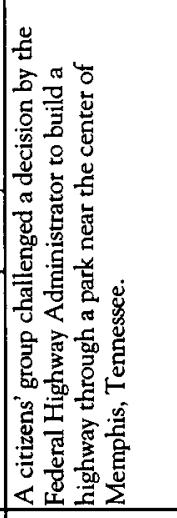 & 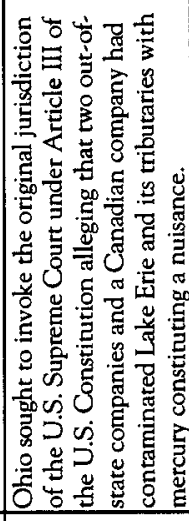 & 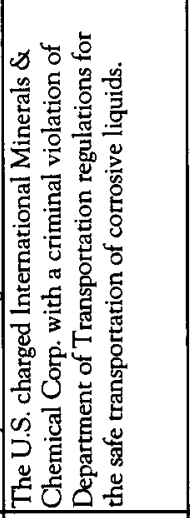 & 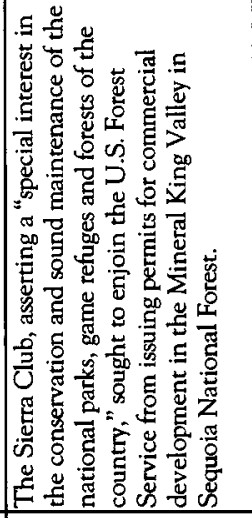 \\
\hline 苟 & 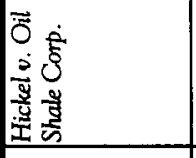 & 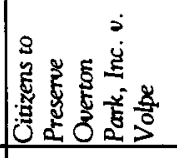 & 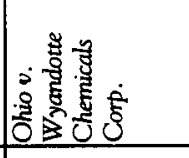 & 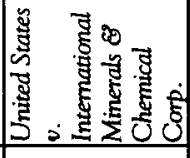 & 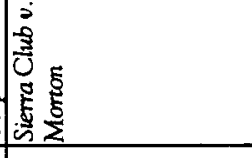 \\
\hline$H$ & i & R & 요요 & iR & $\approx$ \\
\hline
\end{tabular}




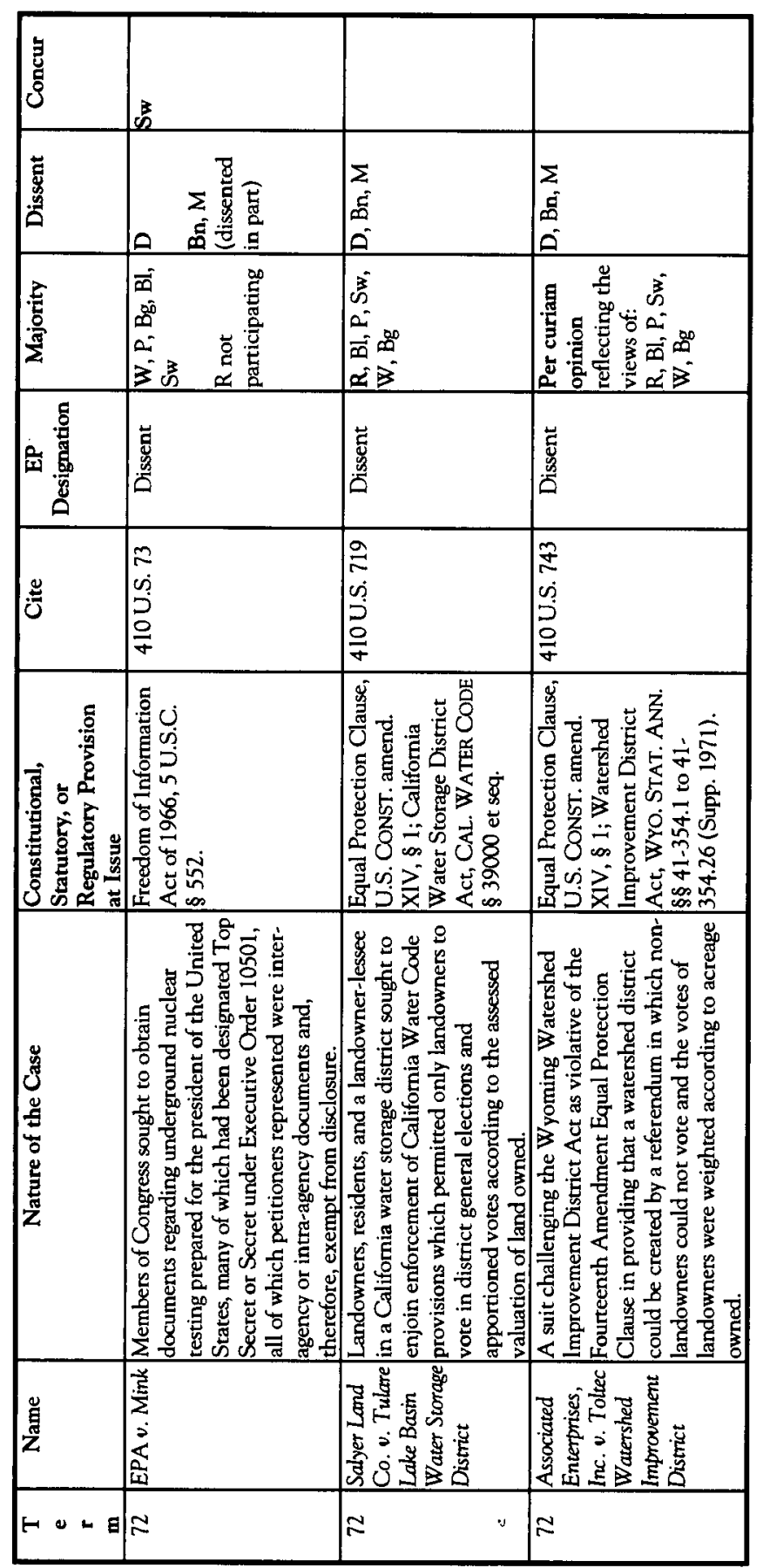




\begin{tabular}{|c|c|c|}
\hline 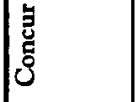 & & \\
\hline $\begin{array}{l}\text { 茑 } \\
\text { 总 } \\
\end{array}$ & & 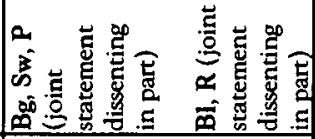 \\
\hline 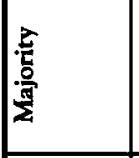 & 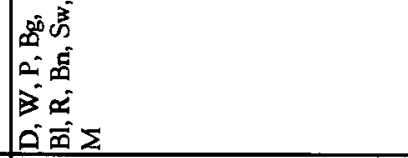 & 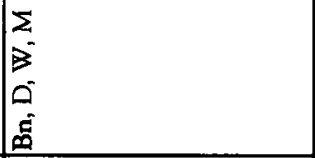 \\
\hline 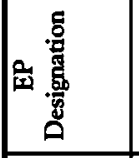 & 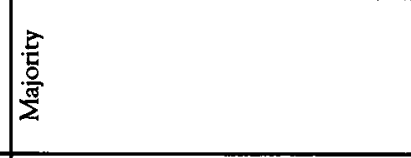 & 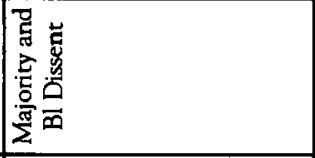 \\
\hline$\ddot{~}$ & 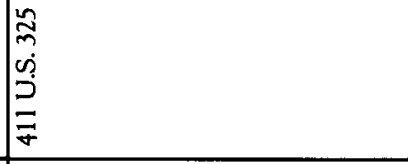 & 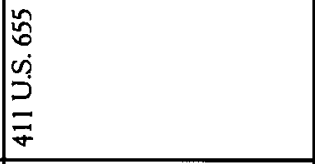 \\
\hline 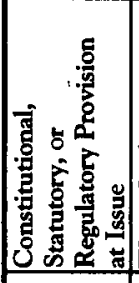 & 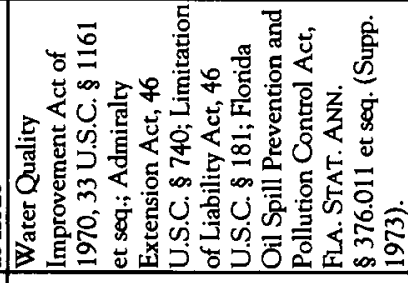 & 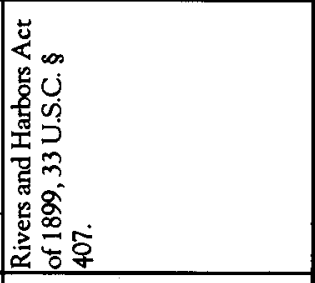 \\
\hline 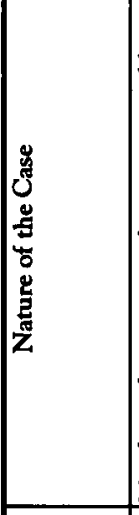 & 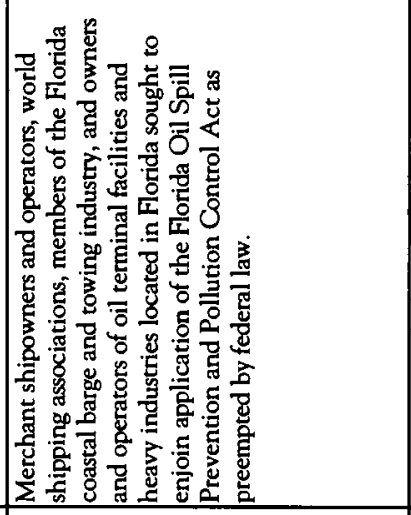 & 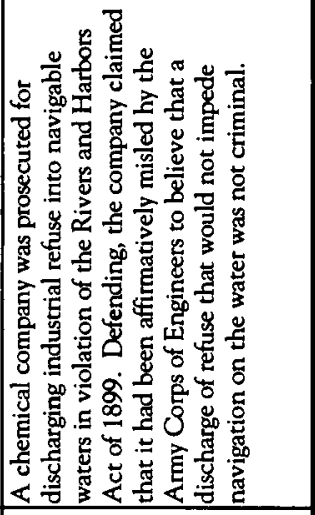 \\
\hline 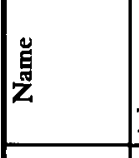 & 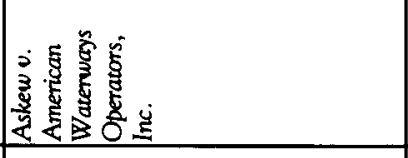 & 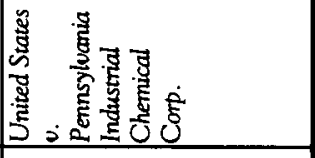 \\
\hline$\mapsto \bullet \leftarrow$ 日 & $\approx$ & $\approx$ \\
\hline
\end{tabular}




\begin{tabular}{|c|c|c|c|c|}
\hline 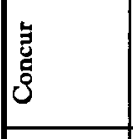 & 品 & & 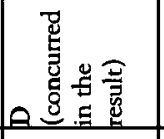 & 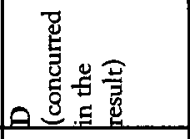 \\
\hline & 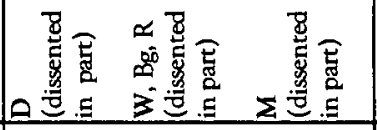 & & & \\
\hline 竞 & 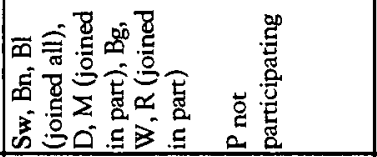 & 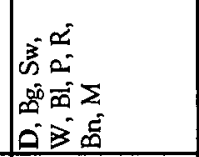 & 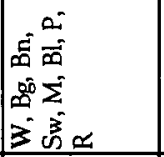 & 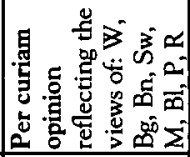 \\
\hline 产 & 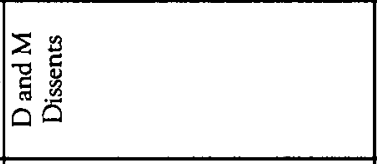 & $\mid \frac{\vec{Z}}{\frac{D}{\pi}}$ & 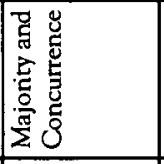 & 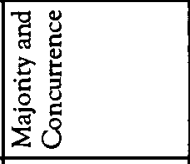 \\
\hline Ё & & 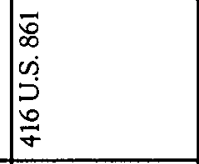 & 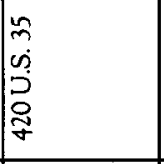 & 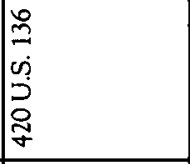 \\
\hline 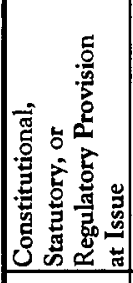 & 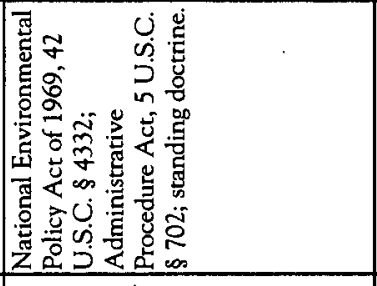 & 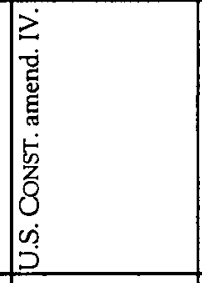 & 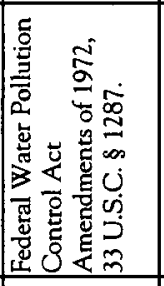 & 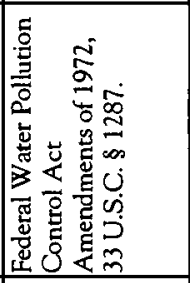 \\
\hline 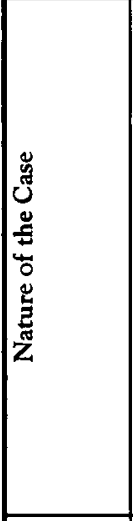 & 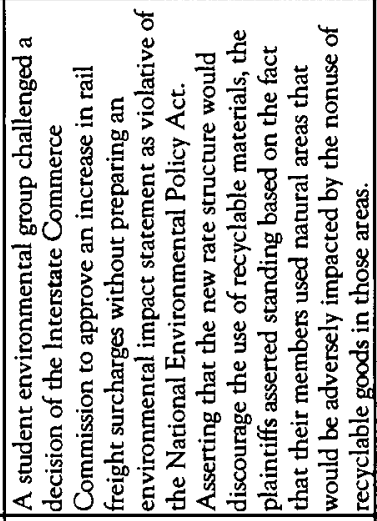 & 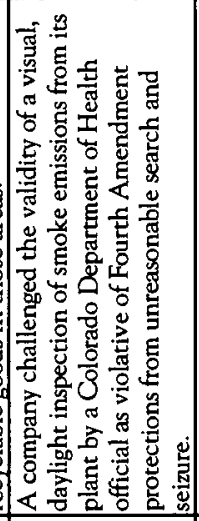 & 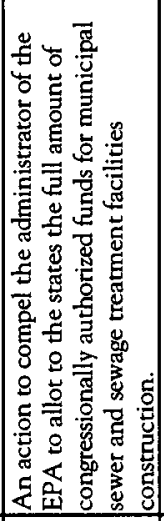 & 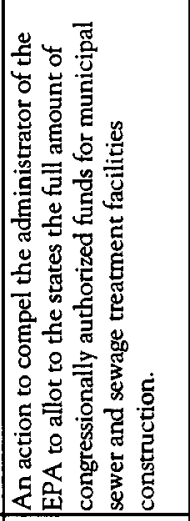 \\
\hline 莺 & 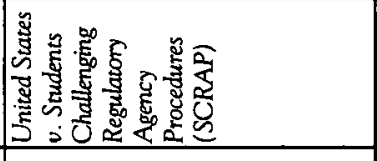 & 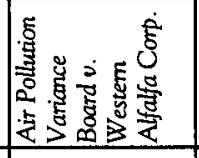 & 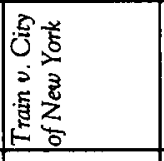 & 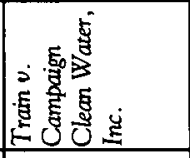 \\
\hline 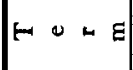 & & $\approx$ & \pm & It \\
\hline
\end{tabular}




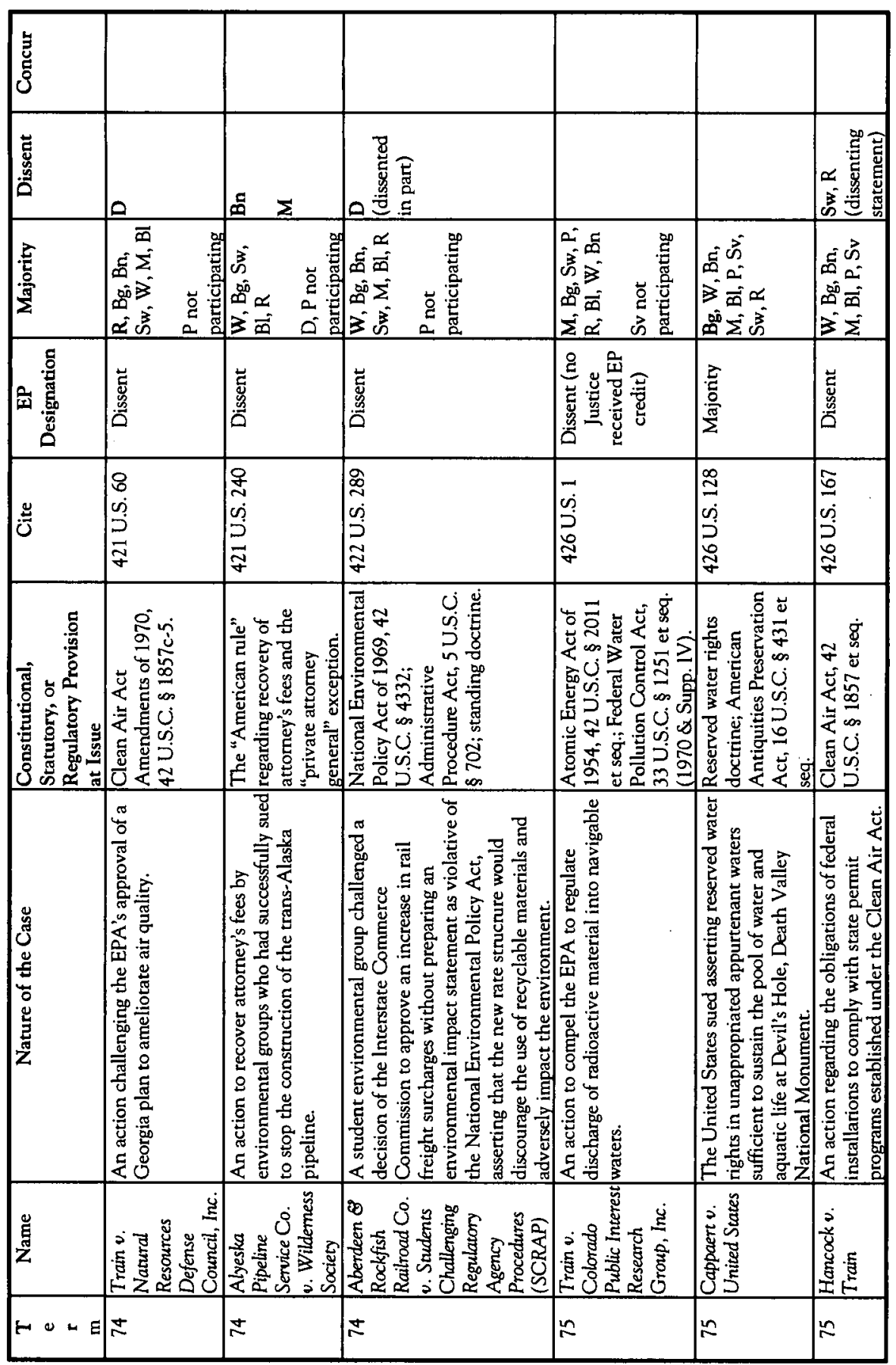




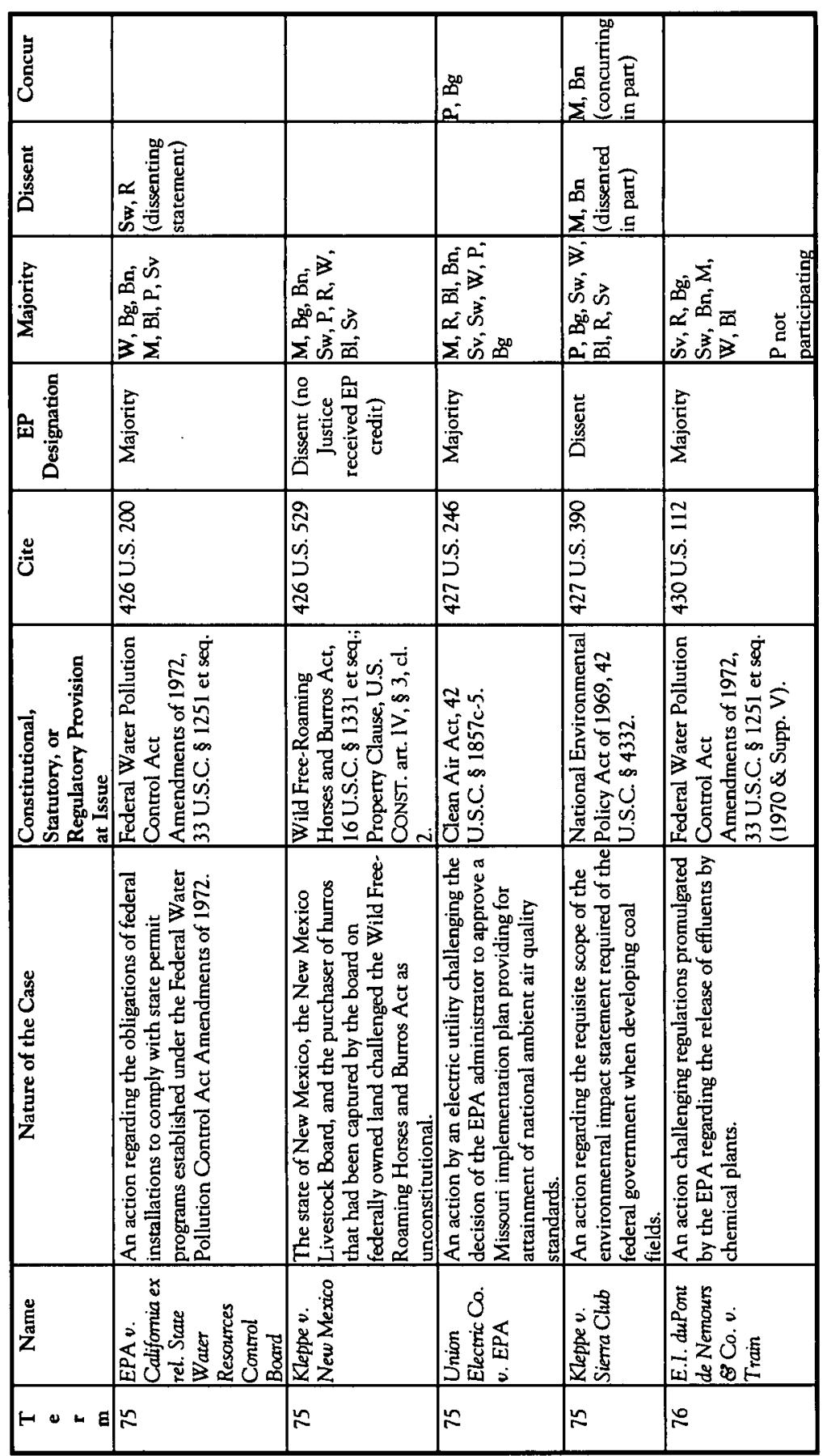




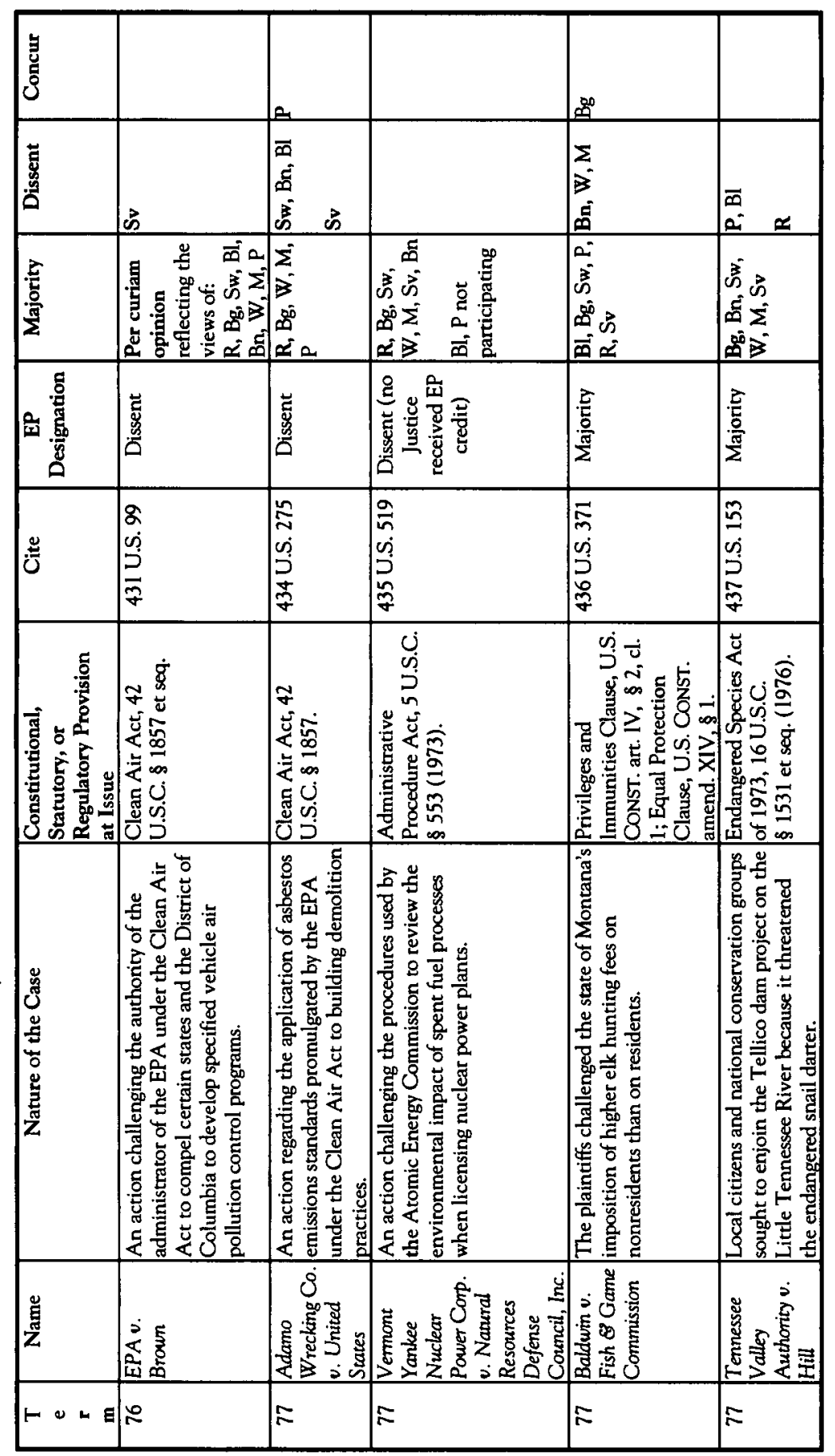




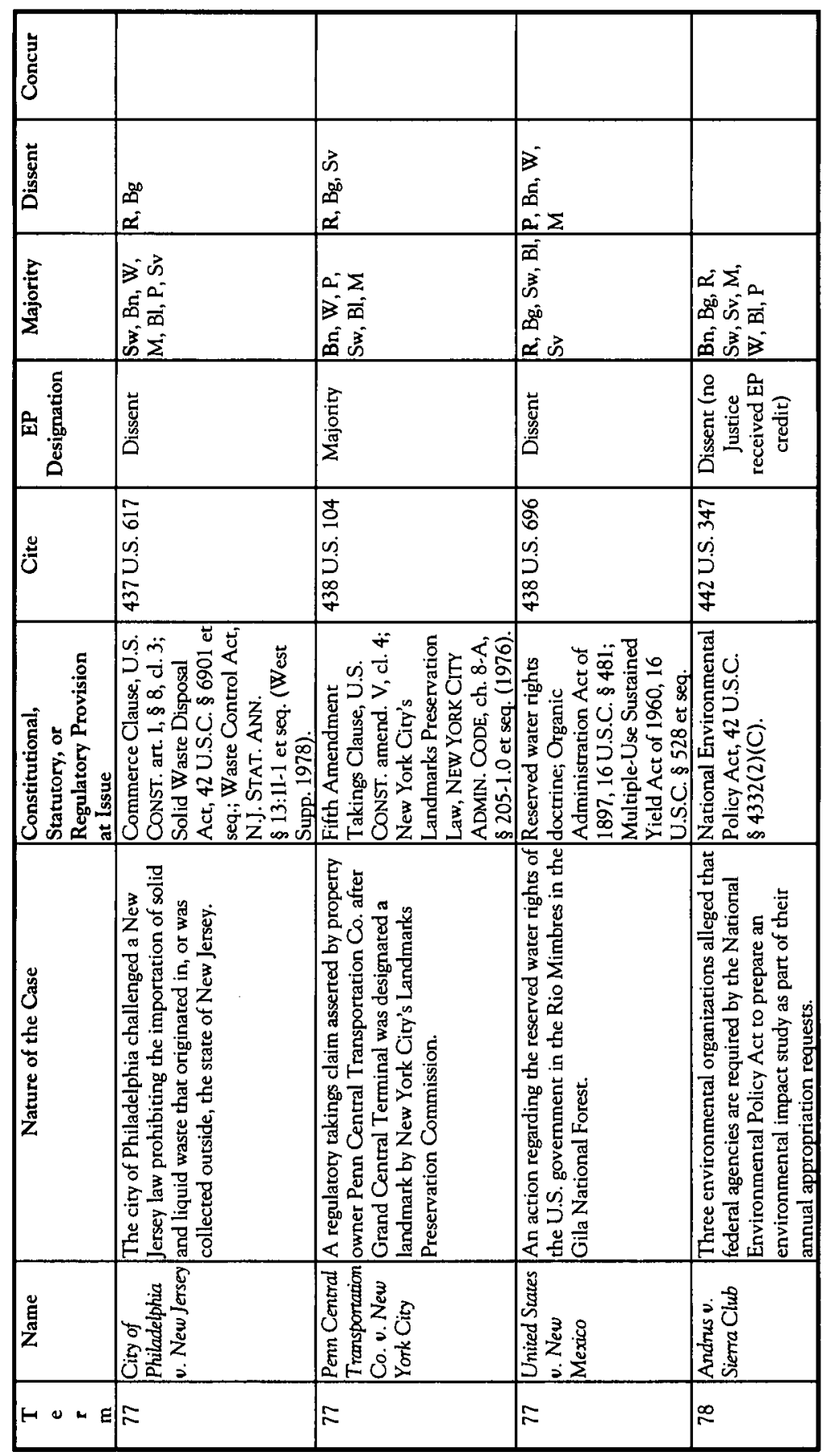




\begin{tabular}{|c|c|c|c|c|c|}
\hline 总 & 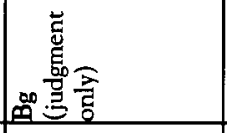 & & & & $\mid \begin{array}{l}\Sigma \\
\overrightarrow{0}\end{array}$ \\
\hline 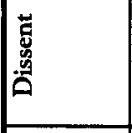 & & 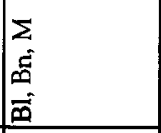 & $\Sigma$ & 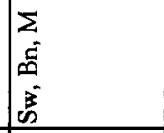 & 3 \\
\hline 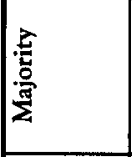 & 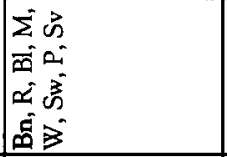 & 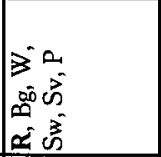 & 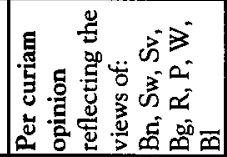 & 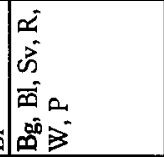 & 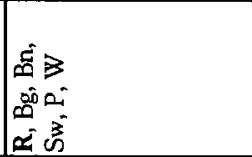 \\
\hline 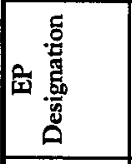 & 竞 & 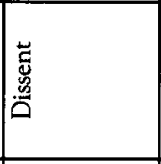 & 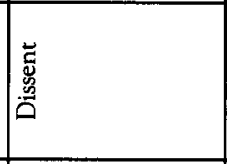 & 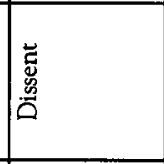 & 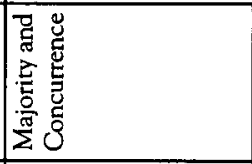 \\
\hline ث̈ & 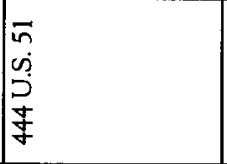 & 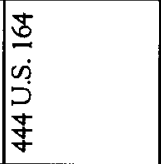 & 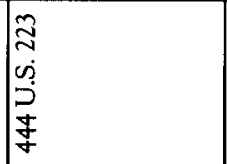 & 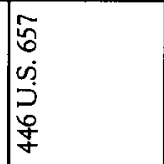 & 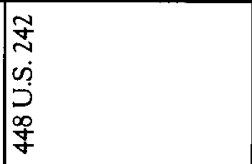 \\
\hline 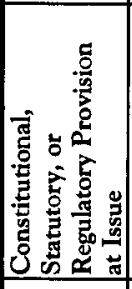 & 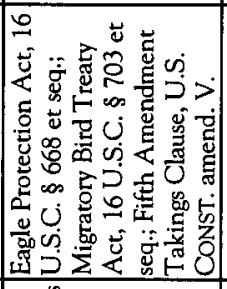 & 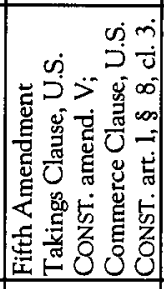 & 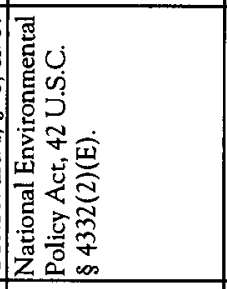 & 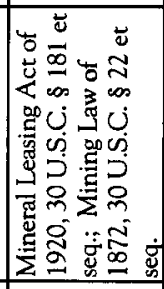 & 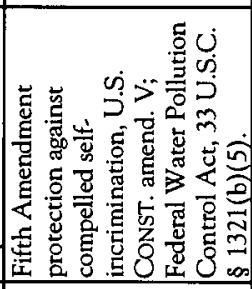 \\
\hline 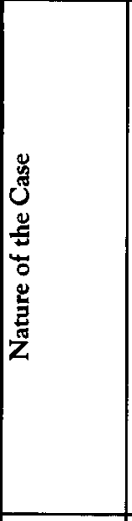 & 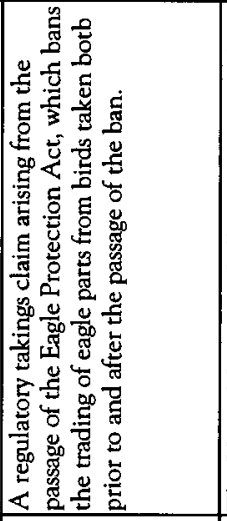 & 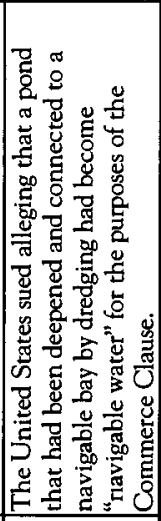 & 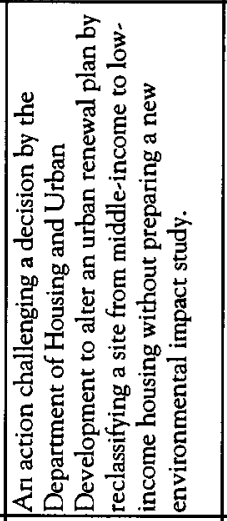 & 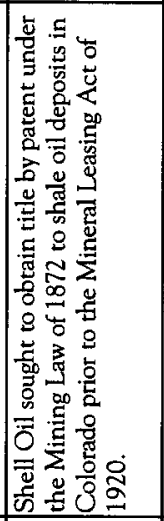 & 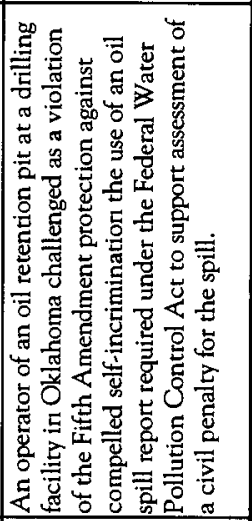 \\
\hline 尝 & 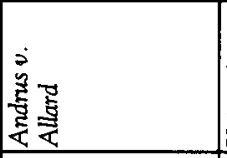 & 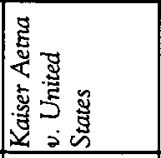 & 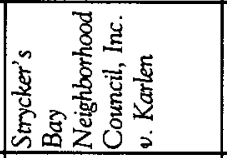 & 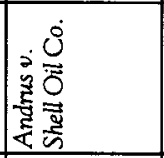 & 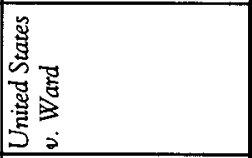 \\
\hline $\mid \begin{array}{lll}1 & 0 & \cdots\end{array}$ & 2 & 2 & 2 & 2 & 2 \\
\hline
\end{tabular}




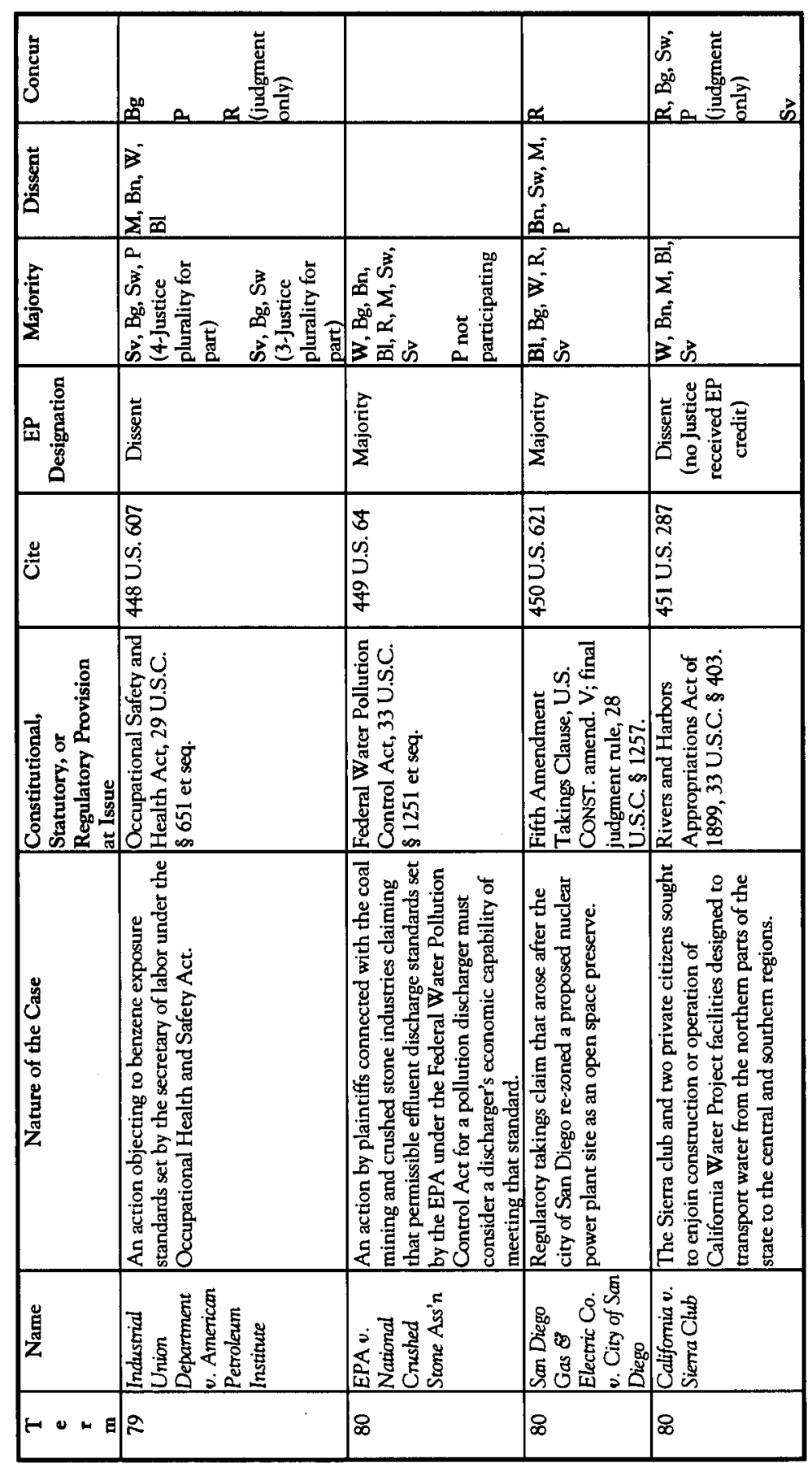




\begin{tabular}{|c|c|c|c|c|}
\hline $\begin{array}{l}\text { 总 } \\
\text { 。 }\end{array}$ & مـ & 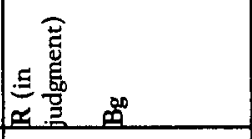 & 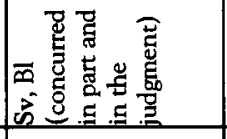 & $z$ \\
\hline & & & & 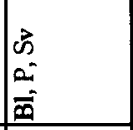 \\
\hline 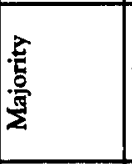 & 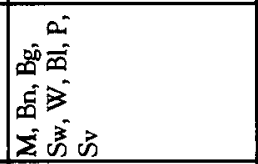 & 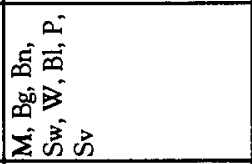 & 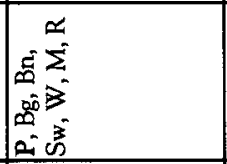 & 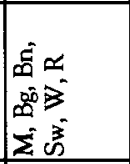 \\
\hline 范 & 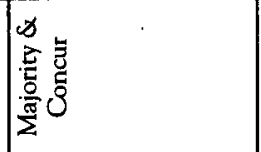 & 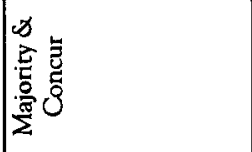 & 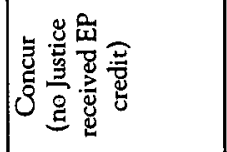 & 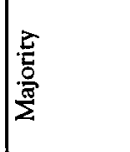 \\
\hline$\stackrel{\Xi}{\tilde{Z}}$ & 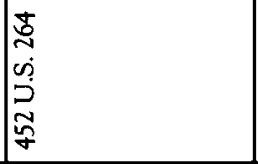 & 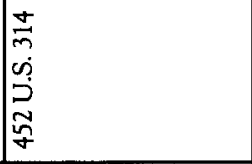 & 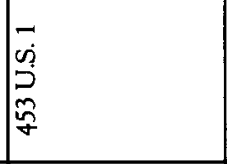 & 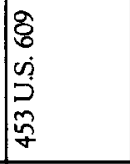 \\
\hline 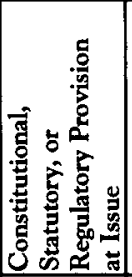 & 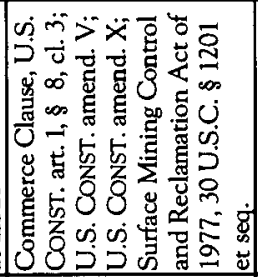 & 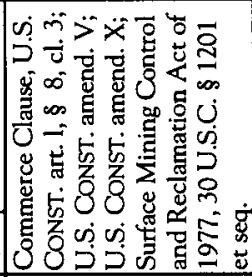 & 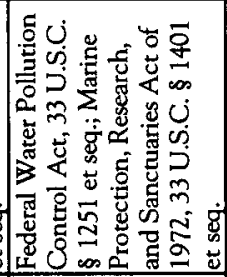 & 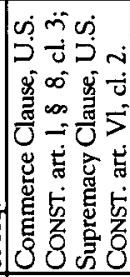 \\
\hline 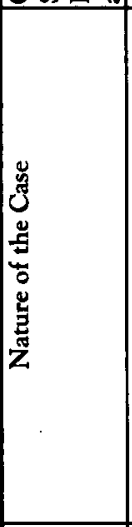 & 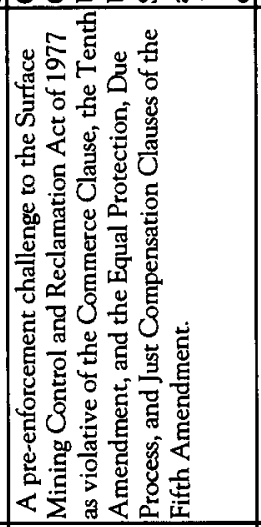 & 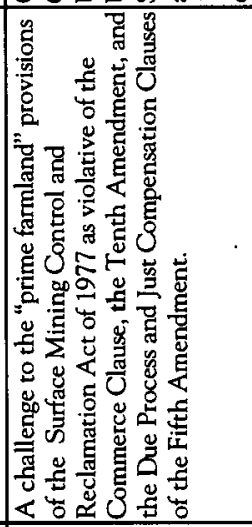 & 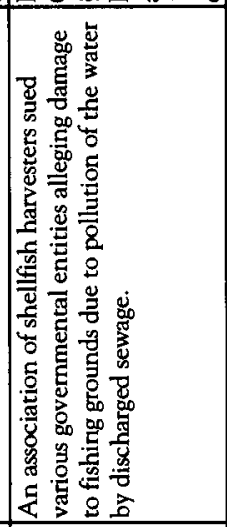 & 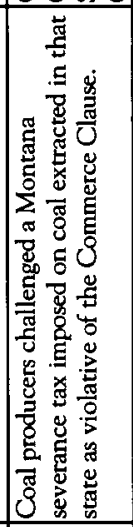 \\
\hline 莺 & 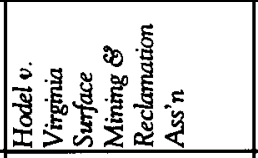 & 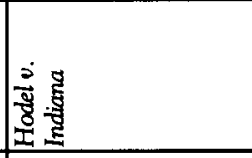 & 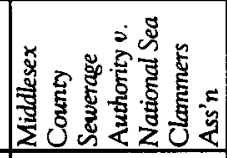 & 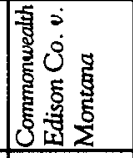 \\
\hline 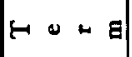 & & $\infty$ & 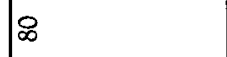 & 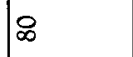 \\
\hline
\end{tabular}




\begin{tabular}{|c|c|c|c|c|c|}
\hline 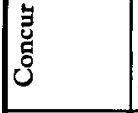 & 品 & & of & & 贵 \\
\hline & & & $B$ & 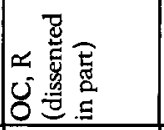 & \\
\hline 产 & 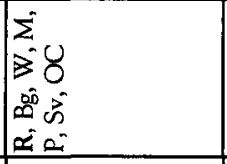 & 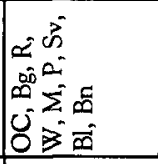 & 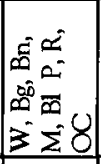 & 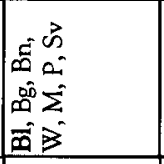 & 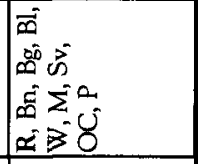 \\
\hline 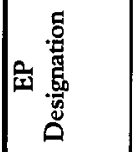 & 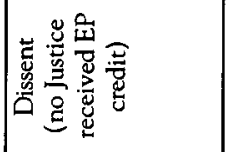 & 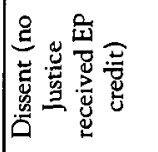 & 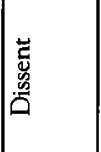 & \begin{tabular}{|l}
$\frac{2}{2}$ \\
$\frac{0}{0}$ \\
$\frac{\pi}{2}$
\end{tabular} & 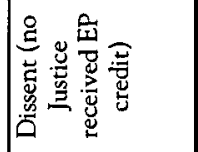 \\
\hline$\ddot{0}$ & 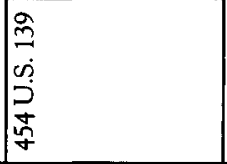 & 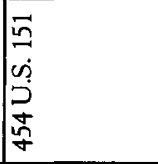 & 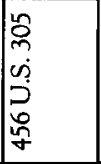 & 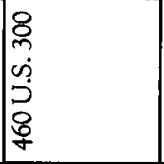 & 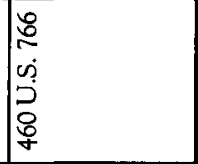 \\
\hline 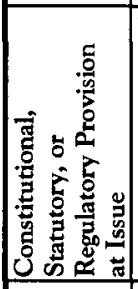 & 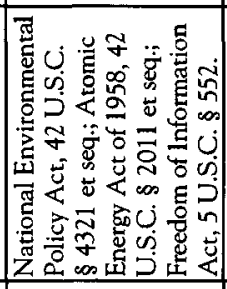 & 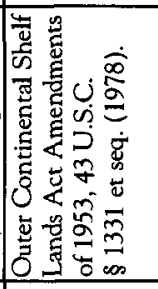 & 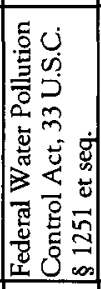 & 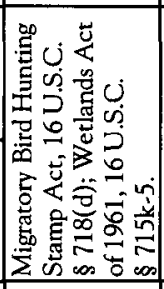 & 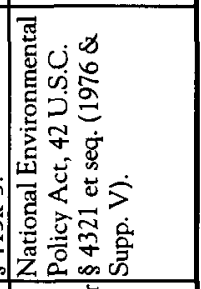 \\
\hline & 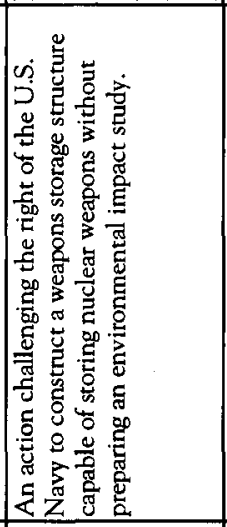 & 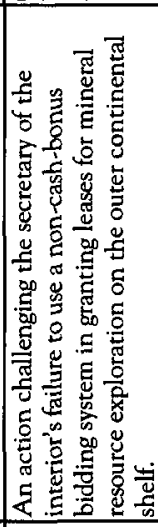 & 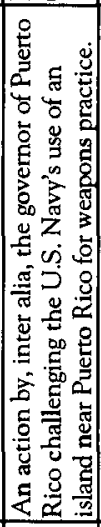 & 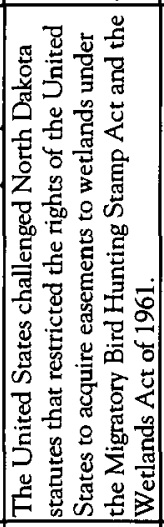 & 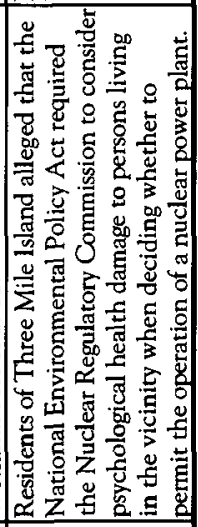 \\
\hline 息 & 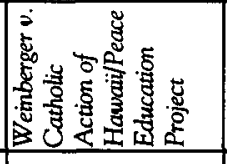 & 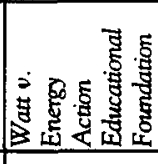 & 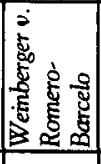 & 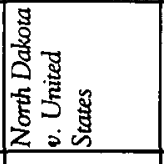 & 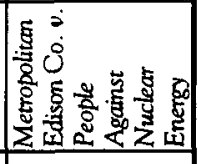 \\
\hline $\begin{array}{llll}H & 0 & \cdots\end{array}$ & $\infty$ & $\vec{\infty}$ & $\infty$ & $\infty$ & $\infty$ \\
\hline
\end{tabular}




\begin{tabular}{|c|c|c|c|c|c|}
\hline 总 & 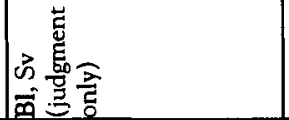 & & & & \\
\hline 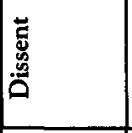 & & & $\begin{array}{ll} & \vec{\infty} \\
\Sigma & \overrightarrow{0} \\
\vec{\infty} & \overrightarrow{0}\end{array}$ & 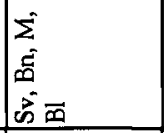 & \\
\hline 焉 & 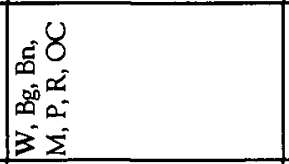 & 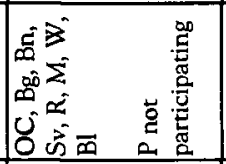 & 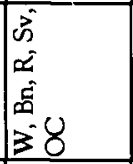 & 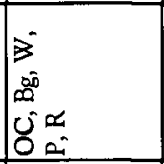 & 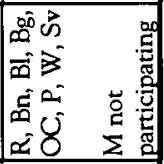 \\
\hline 丞 & 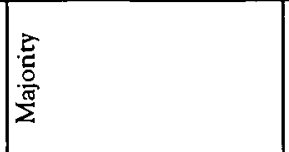 & 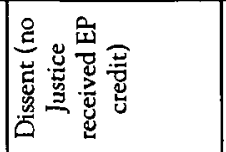 & 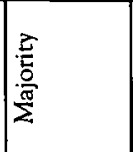 & 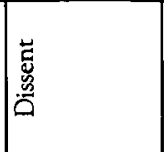 & 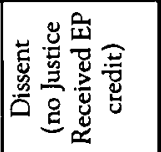 \\
\hline ثّ & 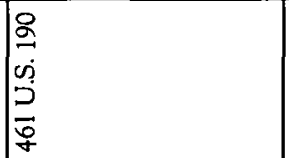 & 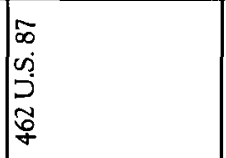 & 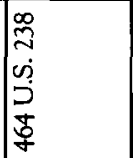 & 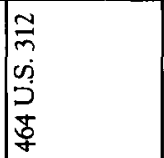 & 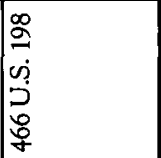 \\
\hline 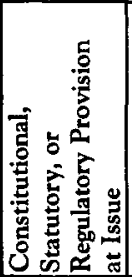 & 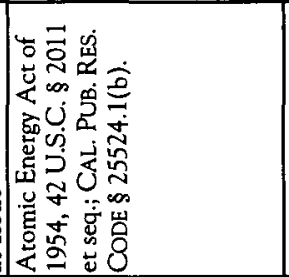 & 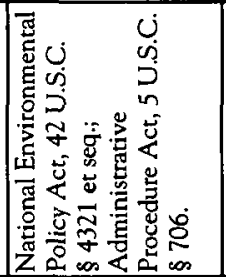 & 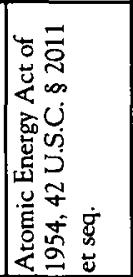 & 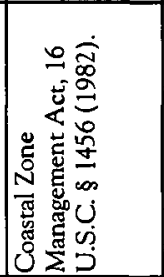 & 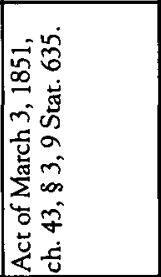 \\
\hline 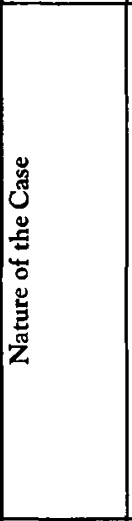 & 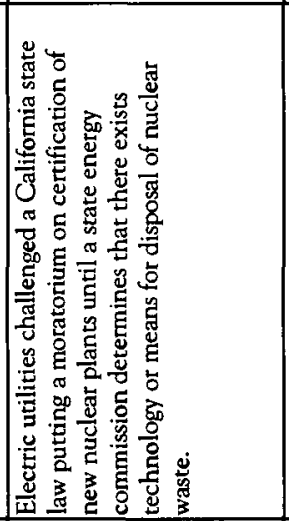 & 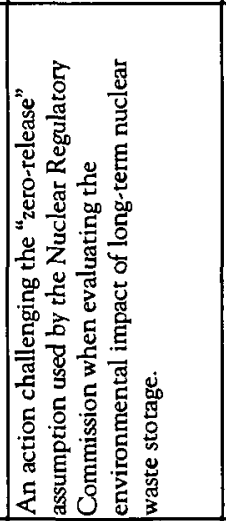 & 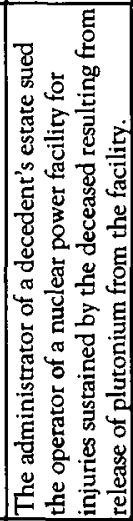 & 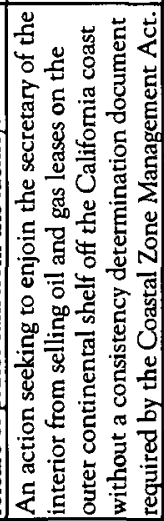 & 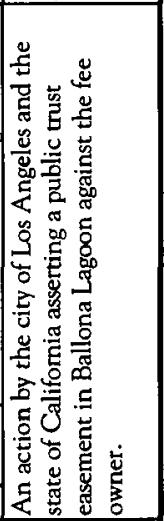 \\
\hline 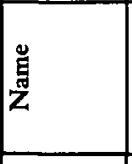 & 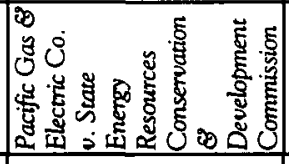 & 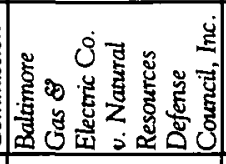 & 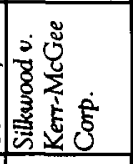 & 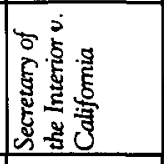 & 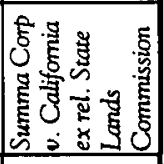 \\
\hline 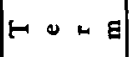 & & $\infty$ & $\infty$ & $\infty$ & $\infty$ \\
\hline
\end{tabular}




\begin{tabular}{|c|c|c|c|c|c|}
\hline 竧 & & & 8 & & \\
\hline 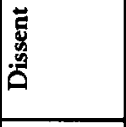 & & & & 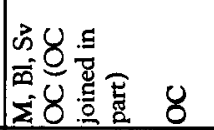 & \\
\hline 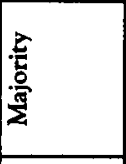 & 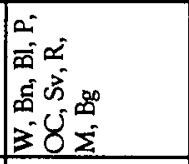 & 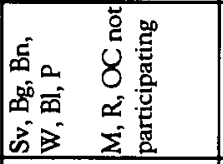 & 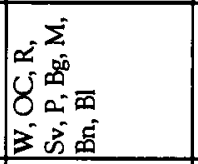 & 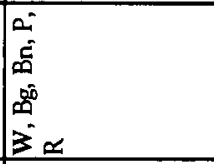 & 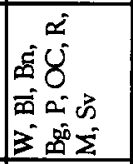 \\
\hline 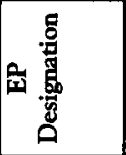 & 总 & 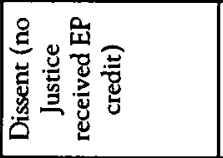 & 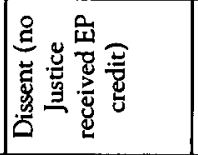 & 军 & $\frac{\sqrt{2}}{\frac{\pi}{5}}$ \\
\hline ث̈ & 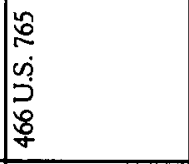 & 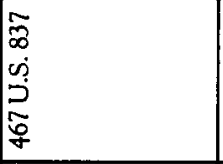 & 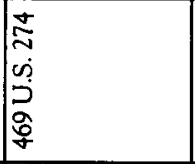 & 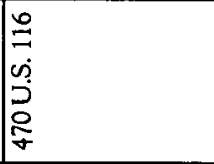 & 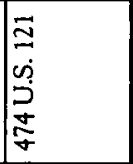 \\
\hline 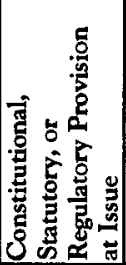 & 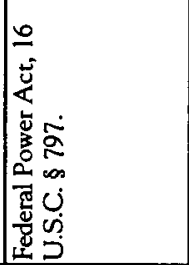 & 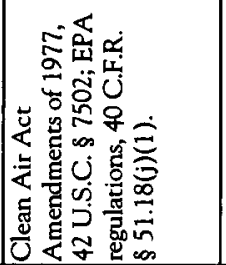 & 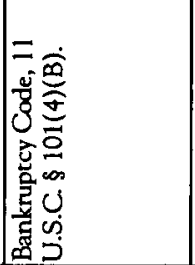 & 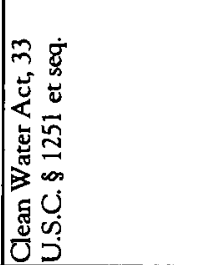 & 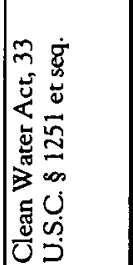 \\
\hline 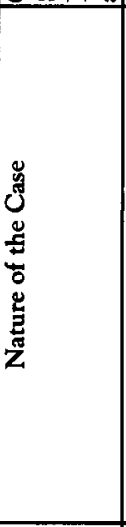 & 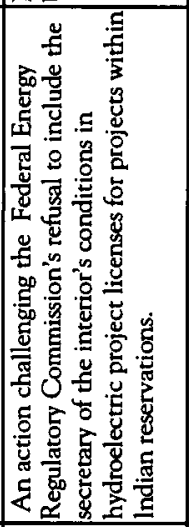 & 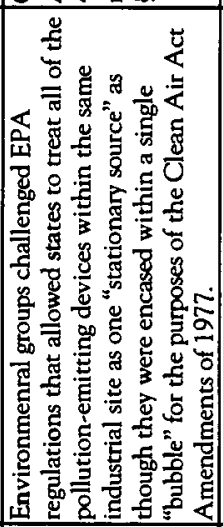 & 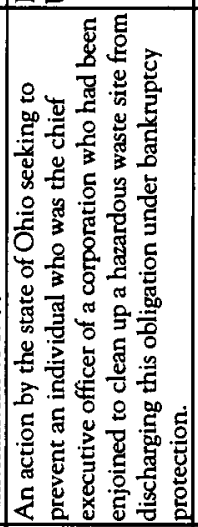 & 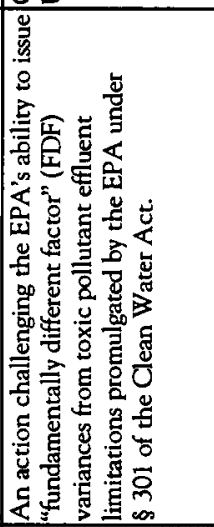 & 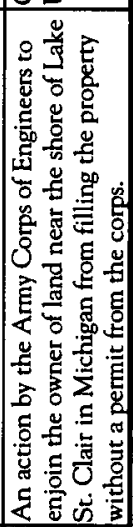 \\
\hline 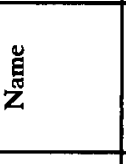 & 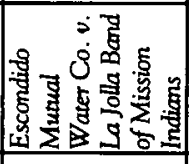 & 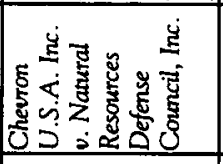 & 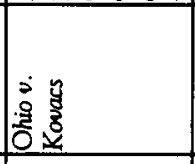 & 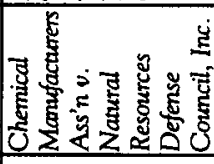 & 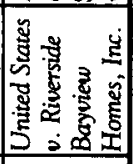 \\
\hline 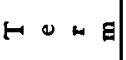 & & $\infty$ & Ф & Б & $\infty$ \\
\hline
\end{tabular}




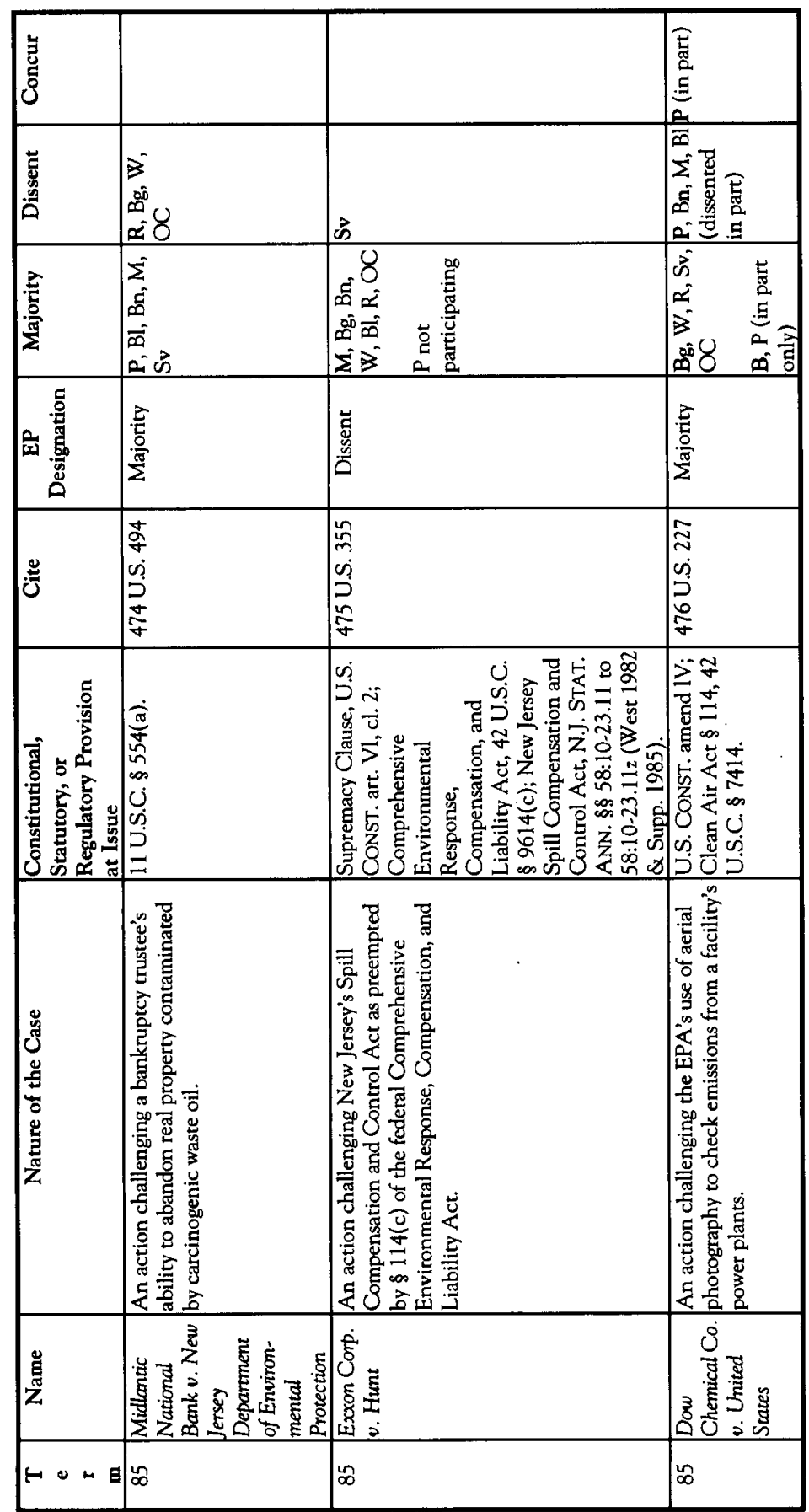




\begin{tabular}{|c|c|c|c|c|}
\hline 急 & & 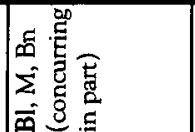 & 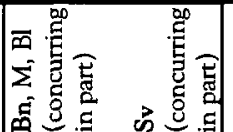 & \\
\hline 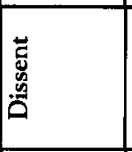 & 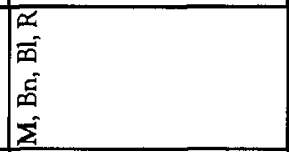 & 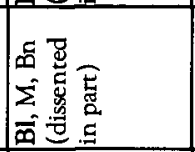 & 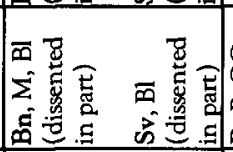 & 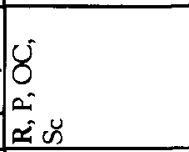 \\
\hline 吾 & $\begin{array}{l}3 \\
n \\
0 \\
0 \\
0 \\
38\end{array}$ & 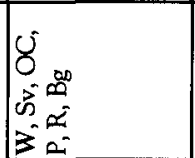 & 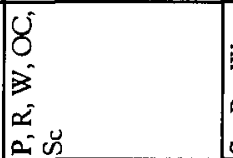 & 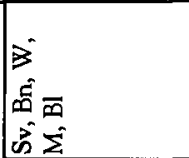 \\
\hline 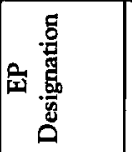 & 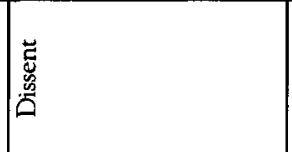 & 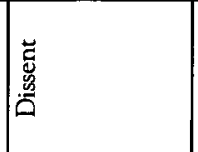 & 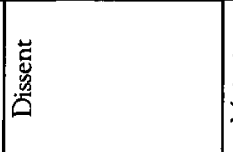 & $\frac{3}{\frac{2}{2}}$ \\
\hline 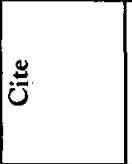 & & 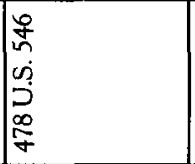 & 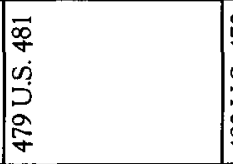 & 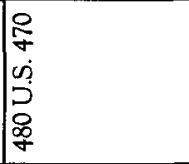 \\
\hline 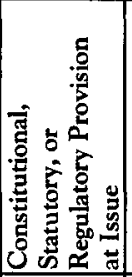 & 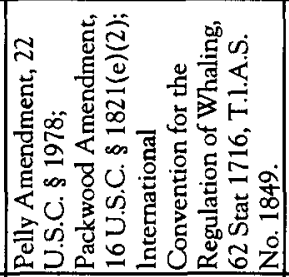 & 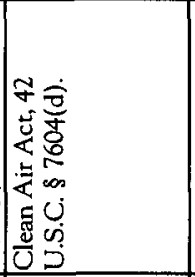 & 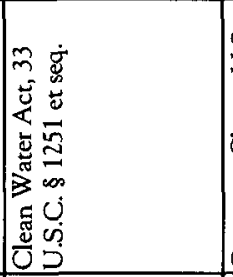 & 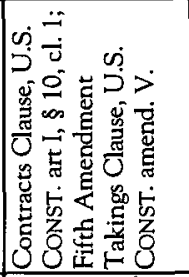 \\
\hline 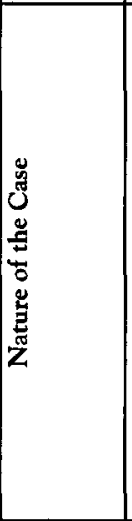 & 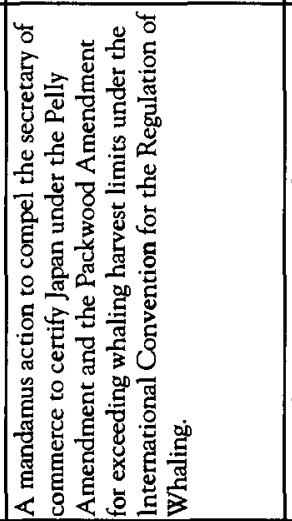 & 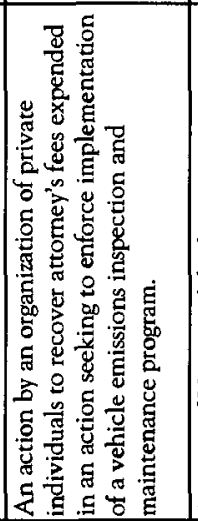 & 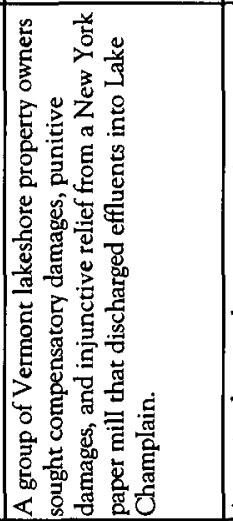 & 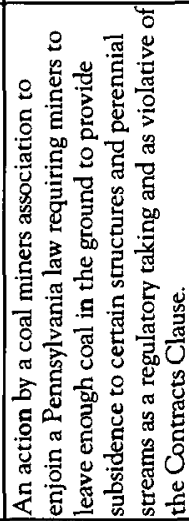 \\
\hline 莺 & 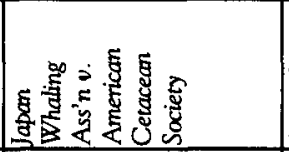 & 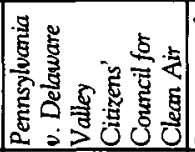 & 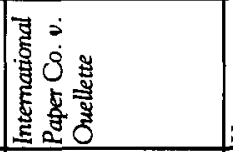 & 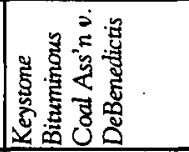 \\
\hline$\mapsto \bullet-E$ & $\infty$ & 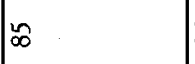 & 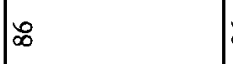 & $\infty$ \\
\hline
\end{tabular}




\begin{tabular}{|c|c|c|c|c|}
\hline $\begin{array}{l}\text { 总 } \\
\text { ठ }\end{array}$ & 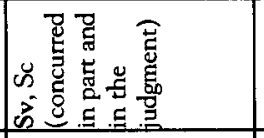 & & & 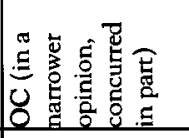 \\
\hline & & 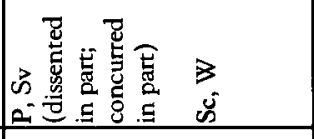 & 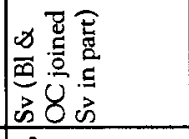 & 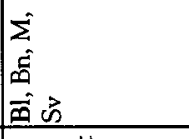 \\
\hline$\frac{E}{\frac{5}{\pi}}$ & 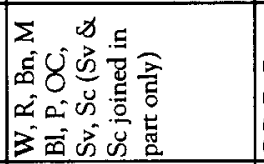 & 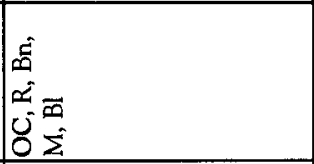 & 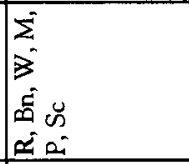 & 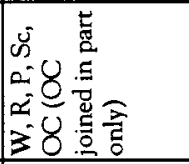 \\
\hline 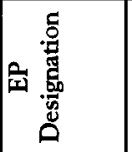 & 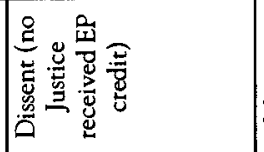 & $\begin{array}{l}\frac{5}{5} \\
\frac{0}{2} \\
\frac{\pi}{2}\end{array}$ & 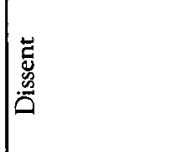 & 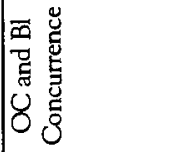 \\
\hline 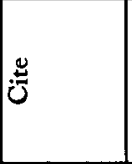 & 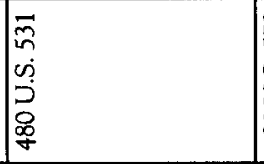 & 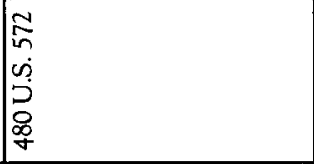 & 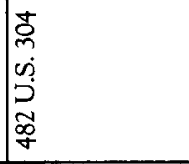 & 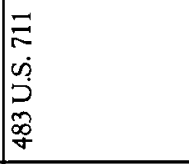 \\
\hline 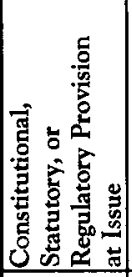 & 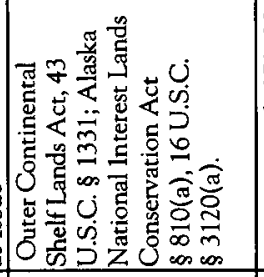 & 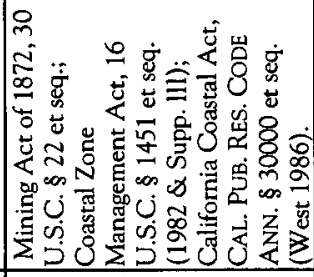 & 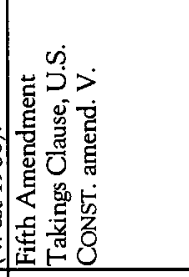 & 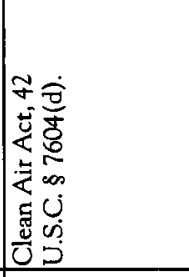 \\
\hline 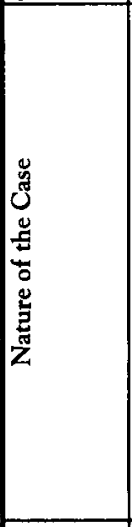 & 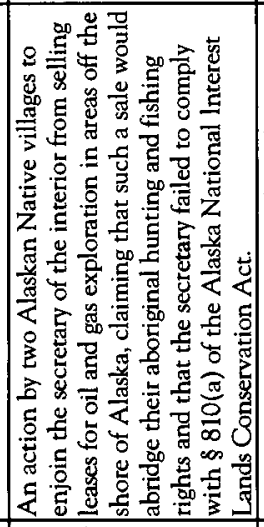 & 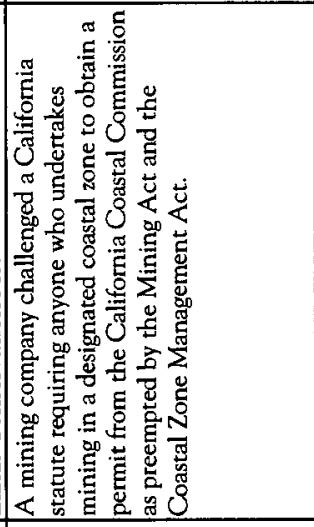 & 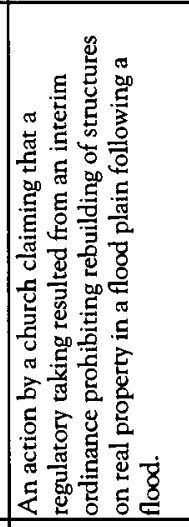 & 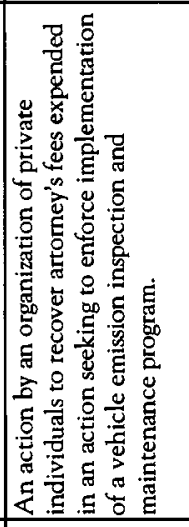 \\
\hline 岁 & 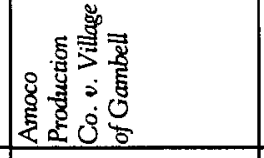 & 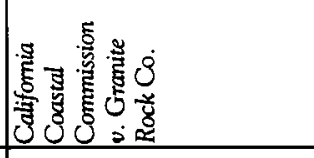 & 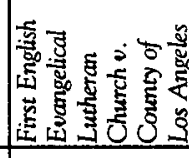 & 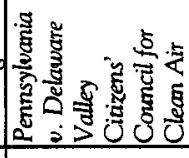 \\
\hline$H \bullet \sim E$ & $1 \infty$ & $\infty$ & $\infty$ & $\infty$ \\
\hline
\end{tabular}




\begin{tabular}{|c|c|c|c|c|c|}
\hline ठ & & 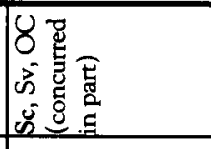 & & E & \\
\hline 蒂 & $\begin{array}{lll}\vec{\infty} & \Sigma & \\
\vec{b} & \bar{\Xi} & \overline{9} \\
\end{array}$ & & 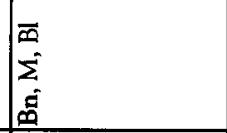 & & \\
\hline $\mid$ & 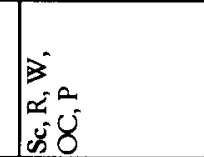 & 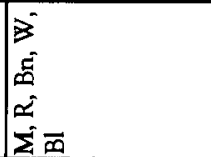 & 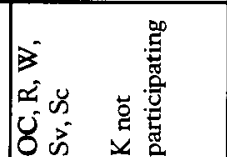 & 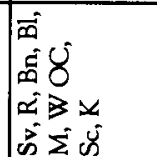 & 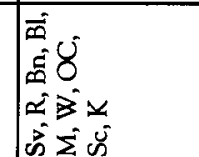 \\
\hline 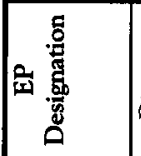 & 菖 & 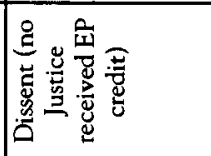 & 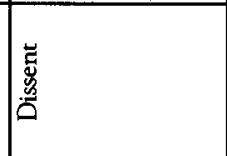 & 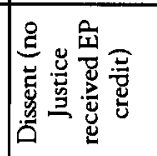 & 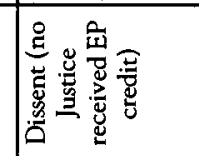 \\
\hline تُ. & 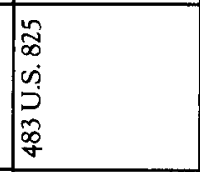 & 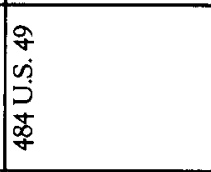 & 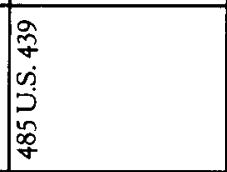 & 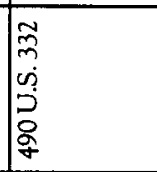 & 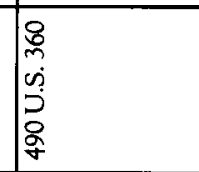 \\
\hline 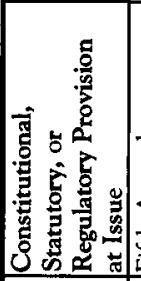 & 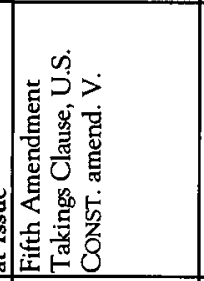 & 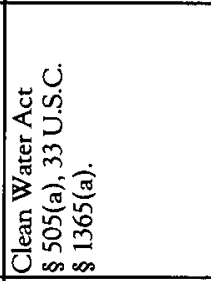 & 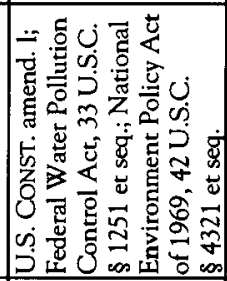 & 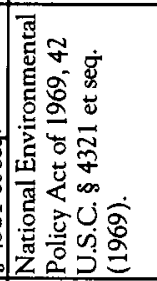 & 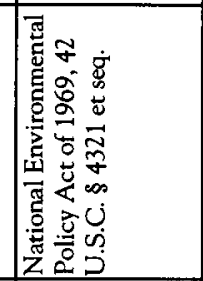 \\
\hline 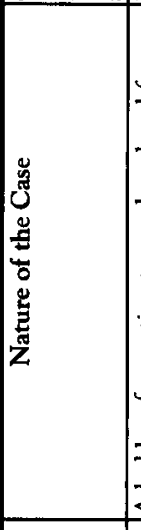 & 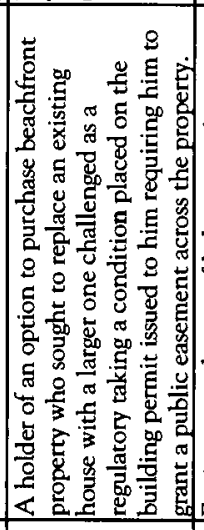 & 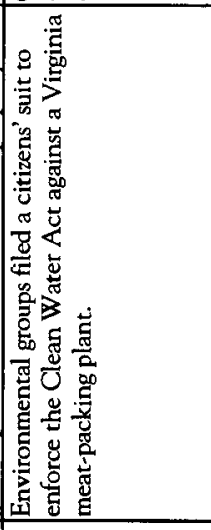 & 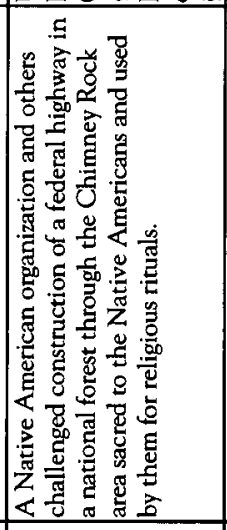 & 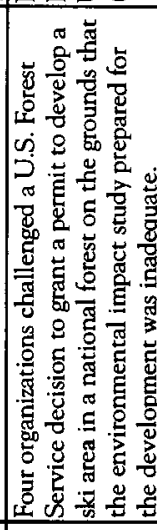 & 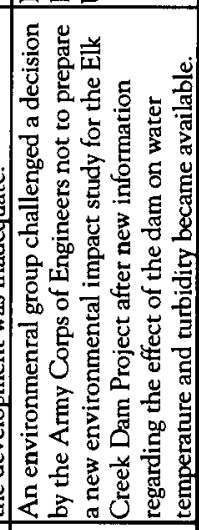 \\
\hline ž & 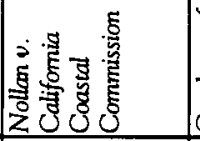 & 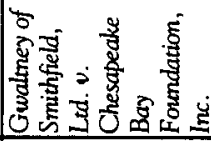 & 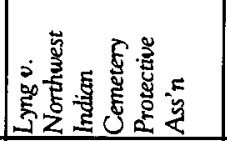 & & है \\
\hline & & & $\infty$ & $1^{\infty}$ & $\infty$ \\
\hline
\end{tabular}




\begin{tabular}{|c|c|c|c|c|}
\hline 描 & 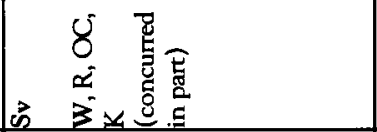 & & & \\
\hline 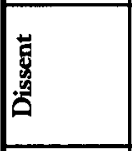 & 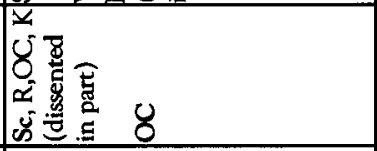 & $\begin{array}{l}\text { D } \\
\Sigma \\
\end{array}$ & & 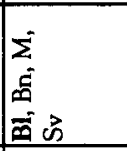 \\
\hline 窇 & 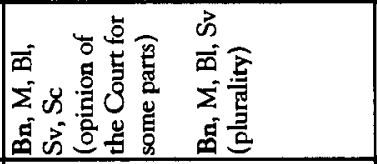 & 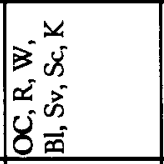 & 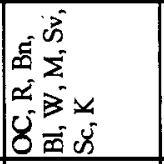 & $\mid \begin{array}{l}3 \\
x-4 \\
58 \\
5 \\
5\end{array}$ \\
\hline 商 & 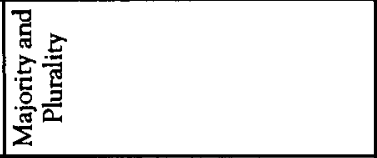 & 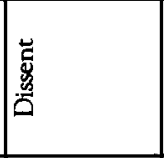 & 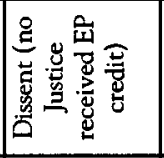 & 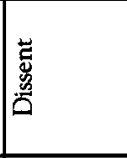 \\
\hline ثِّ & 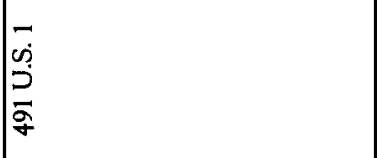 & 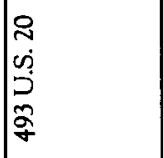 & 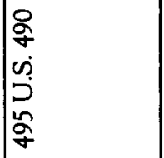 & 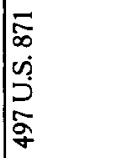 \\
\hline 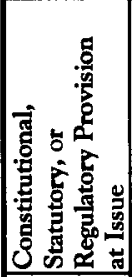 & 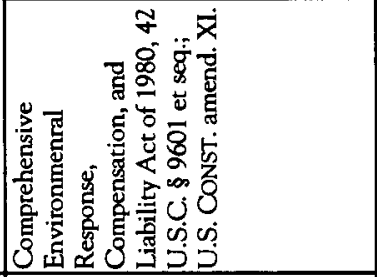 & 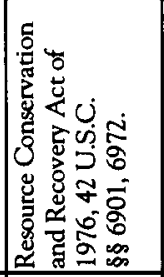 & 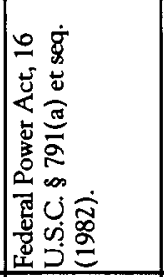 & 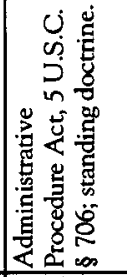 \\
\hline 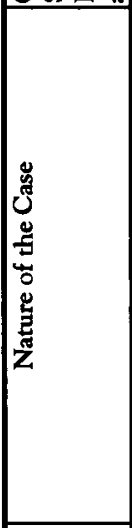 & 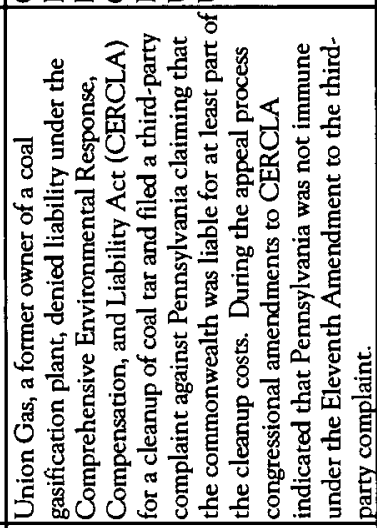 & 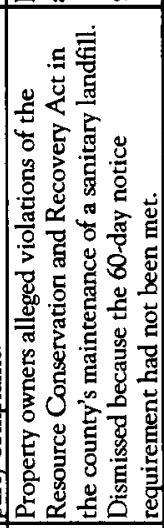 & 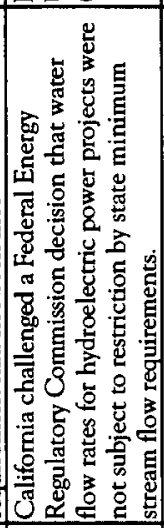 & 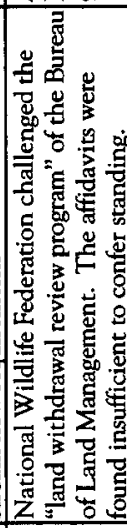 \\
\hline 范 & 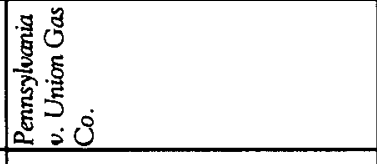 & 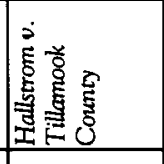 & 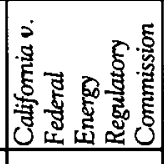 & 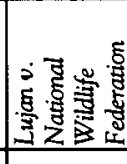 \\
\hline 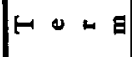 & $\infty$ & $\infty$ & $\infty$ & $\infty$ \\
\hline
\end{tabular}




\begin{tabular}{|c|c|c|c|c|c|}
\hline 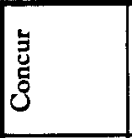 & 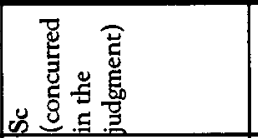 & & & & \\
\hline 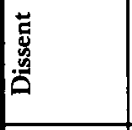 & & & 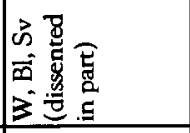 & $\underline{\Omega}$ & $\mid \begin{array}{l}\vec{x} \\
\underline{\alpha}\end{array}$ \\
\hline 产 & 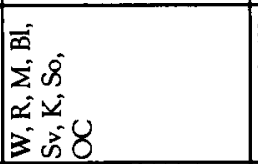 & 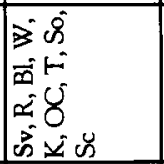 & 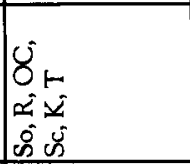 & 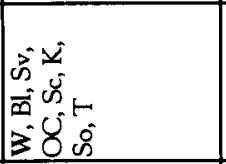 & 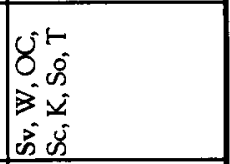 \\
\hline 国 & 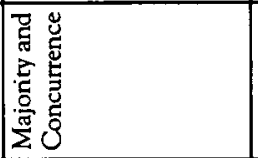 & 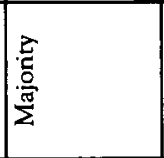 & 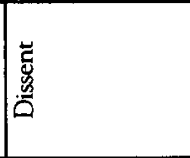 & 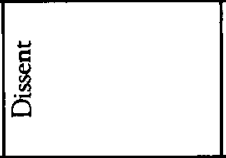 & 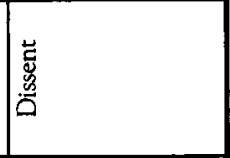 \\
\hline ثّ & 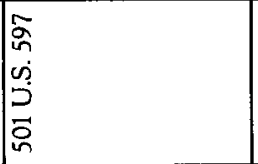 & $\begin{array}{l}\vec{a} \\
\dot{\omega} \\
\dot{p} \\
\ddot{\rho} \\
\dot{n}\end{array}$ & 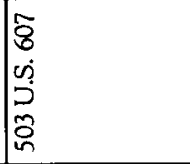 & 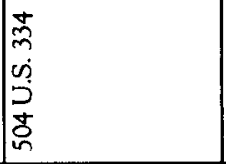 & 位 \\
\hline 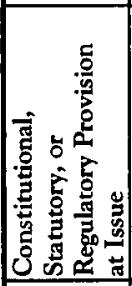 & 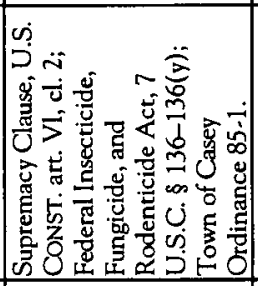 & 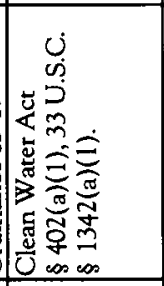 & 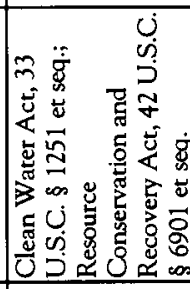 & 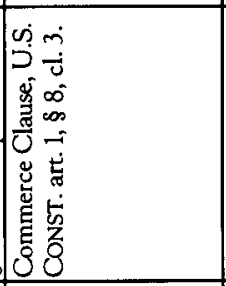 & 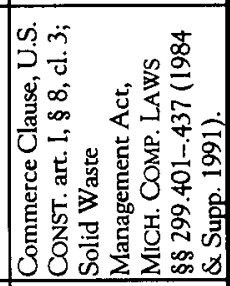 \\
\hline 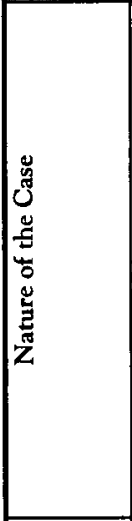 & 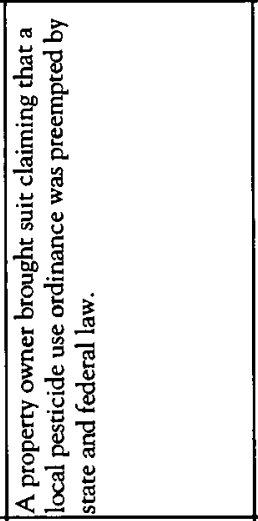 & 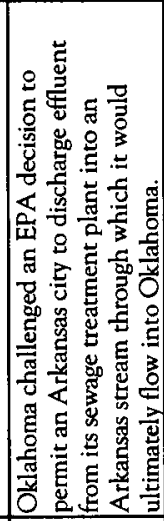 & 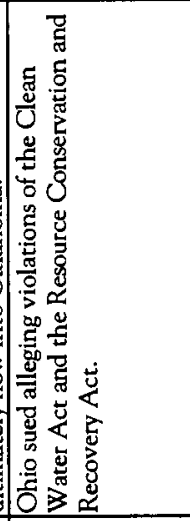 & 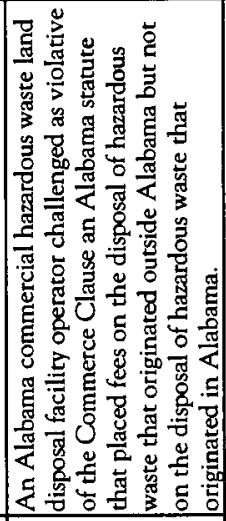 & 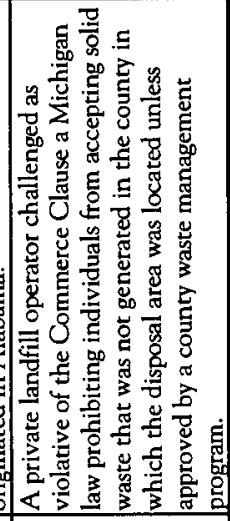 \\
\hline 营 & 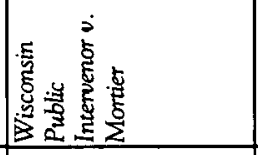 & 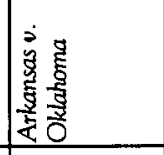 & 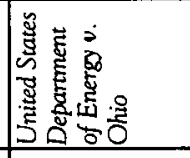 & 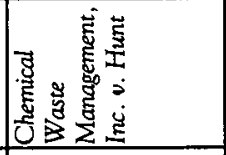 & 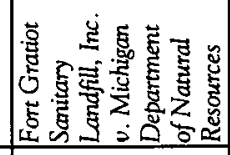 \\
\hline$H \cup \sim z$ & 8 & $\bar{a}$ & $\bar{a}$ & a & $\bar{a}$ \\
\hline
\end{tabular}




\begin{tabular}{|c|c|c|c|}
\hline 急 & 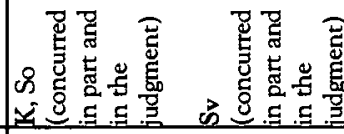 & 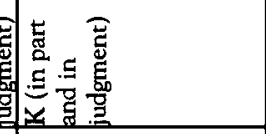 & \\
\hline 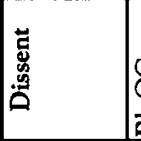 & $\begin{array}{l}8 \\
8 \\
100\end{array}$ & 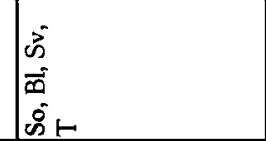 & 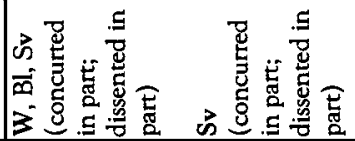 \\
\hline $\begin{array}{l}\frac{2}{2} \\
\frac{5}{2} \\
\frac{\pi}{2}\end{array}$ & 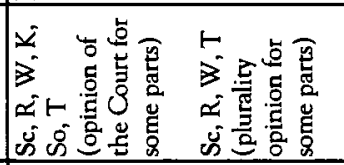 & 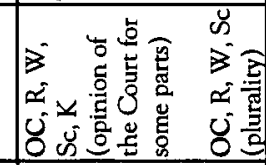 & 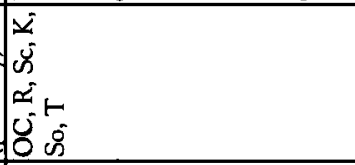 \\
\hline 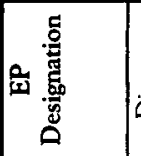 & 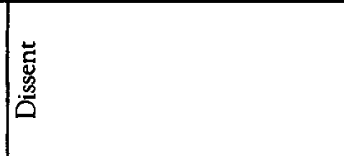 & 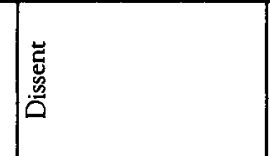 & 总 \\
\hline كُ & 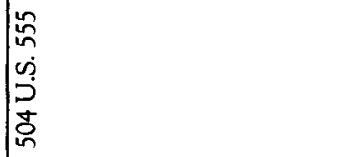 & 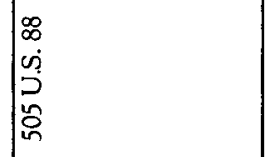 & 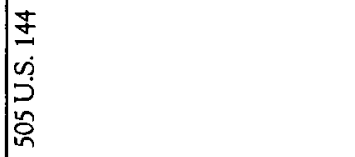 \\
\hline 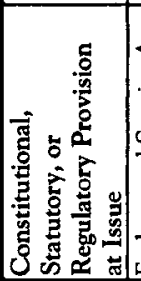 & 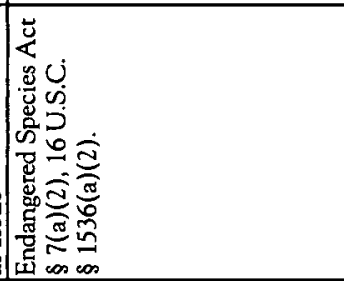 & 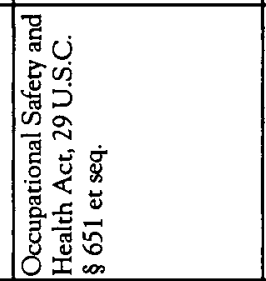 & 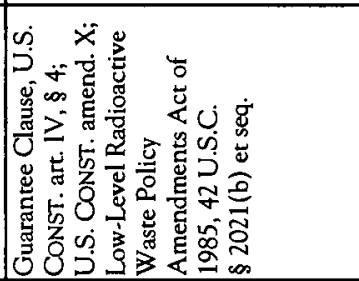 \\
\hline 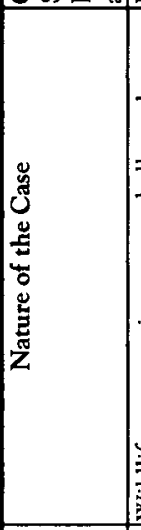 & 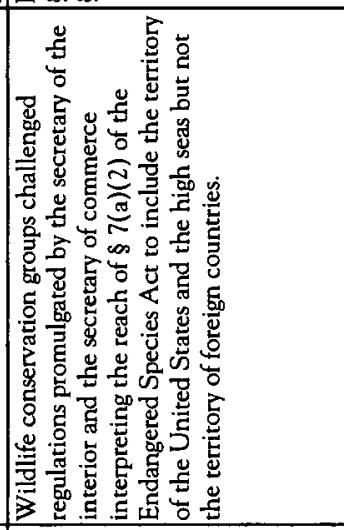 & 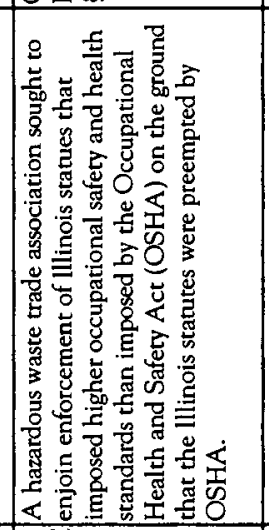 & 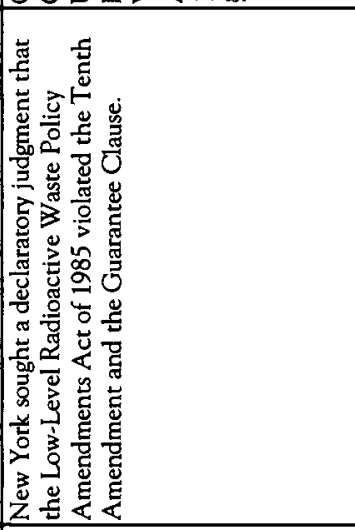 \\
\hline $\begin{array}{l}\text { : } \\
z \\
z\end{array}$ & 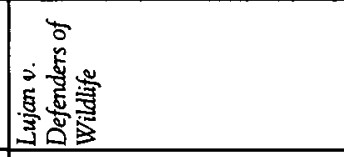 & 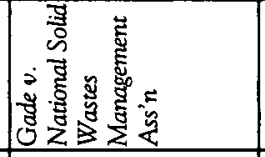 & 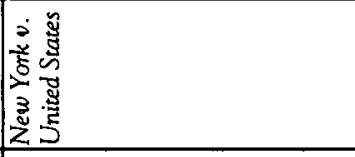 \\
\hline 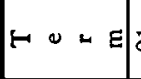 & & $\vec{\sigma}$ & $\bar{\alpha}$ \\
\hline
\end{tabular}




\begin{tabular}{|c|c|c|c|c|c|}
\hline 芑 & & 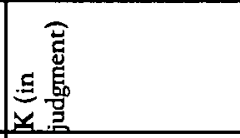 & & & 总 \\
\hline 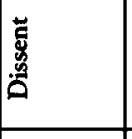 & $\begin{array}{ll}\omega & \\
& \delta \\
\end{array}$ & 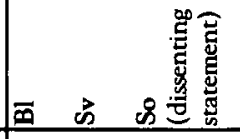 & $\begin{array}{l}\vec{a} \\
\underline{\underline{x}}\end{array}$ & $\begin{array}{l}8 \\
5 \\
5\end{array}$ & 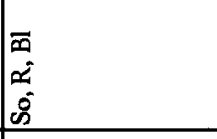 \\
\hline 案 & $\begin{array}{l}x \\
\dot{x} \\
\dot{x}+ \\
\dot{s} \theta\end{array}$ & $\begin{array}{l}1 \\
3 \\
\dot{x} 8 \\
\dot{x} 8\end{array}$ & 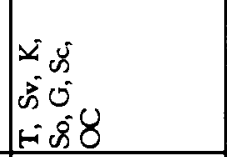 & 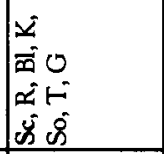 & $\begin{array}{l}1 \\
5 \\
\infty \\
5 \\
5 \\
100 \\
\end{array}$ \\
\hline 突 & 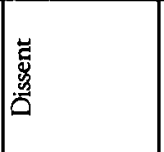 & 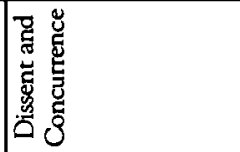 & 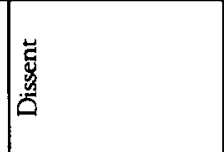 & 胥 & 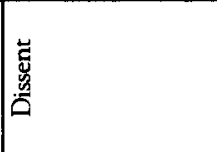 \\
\hline 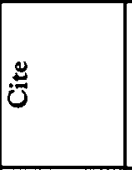 & 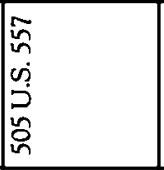 & 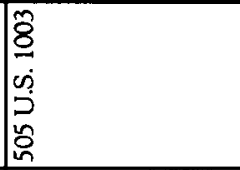 & 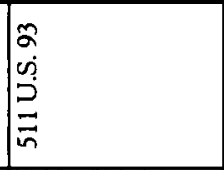 & & $\underset{\infty}{\infty}$ \\
\hline 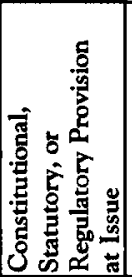 & 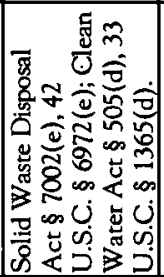 & 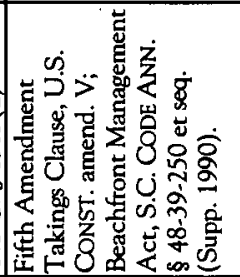 & 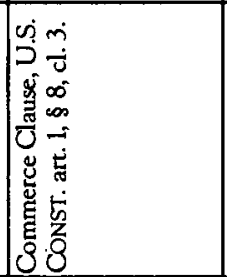 & 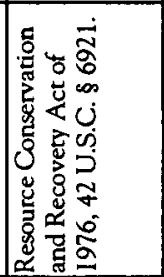 & 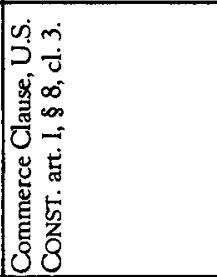 \\
\hline 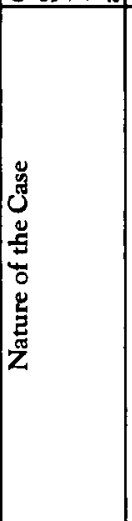 & 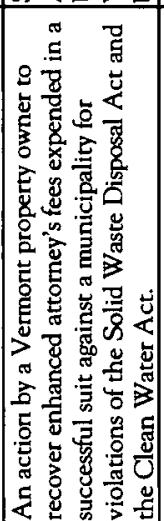 & 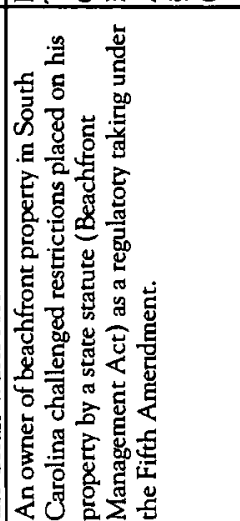 & 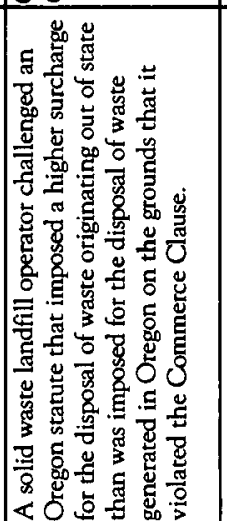 & 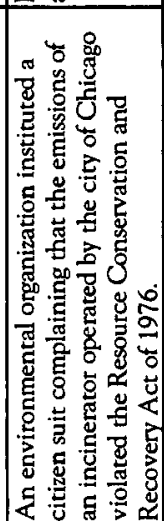 & 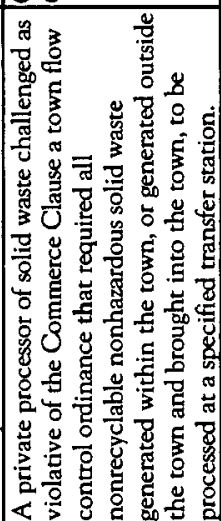 \\
\hline Zू & 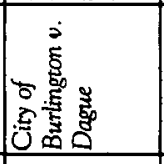 & 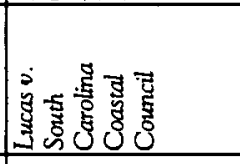 & 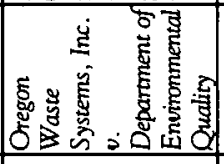 & 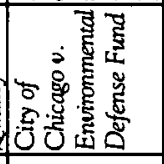 & 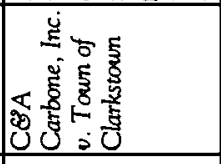 \\
\hline 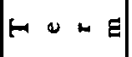 & $\bar{a}$ & $\bar{a}$ & $a$ & 2 & $\hat{\alpha}$ \\
\hline
\end{tabular}




\begin{tabular}{|c|c|c|c|c|}
\hline ठั & 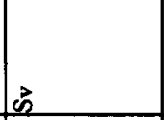 & & 8 & \\
\hline 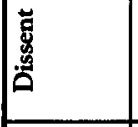 & $\begin{array}{l}\mathscr{y} \\
\hat{H}\end{array}$ & $\begin{array}{ll}0 & \\
\infty & \\
\dot{n} & \\
5 & 8 \\
\end{array}$ & \begin{tabular}{|l}
1 \\
$x$ \\
$x$ \\
$\tilde{x}$ \\
0
\end{tabular} & \\
\hline & 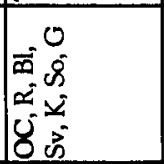 & 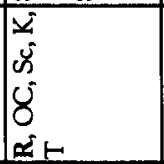 & $\begin{array}{l}5 \\
0 \\
80 \\
0 \\
0 \\
50 \\
8\end{array}$ & 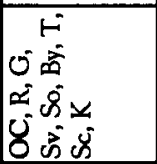 \\
\hline 宝 & 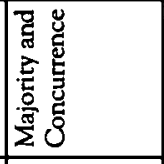 & 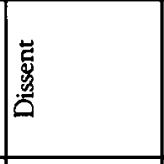 & 㺃 & 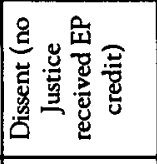 \\
\hline ث̈ & $\begin{array}{l}8 \\
\vdots \\
\infty \\
\vdots \\
\vdots \\
\vdots \\
\text { in } \\
\end{array}$ & 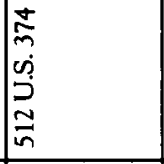 & 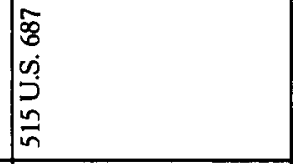 & 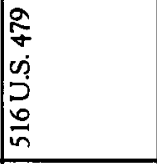 \\
\hline 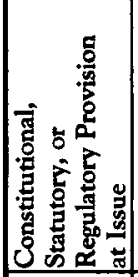 & 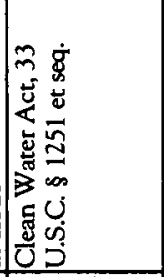 & 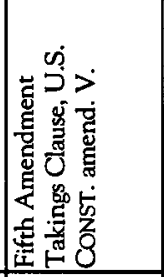 & 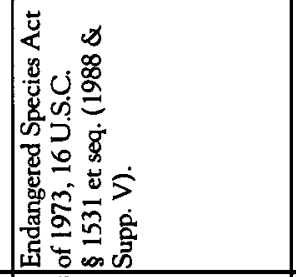 & 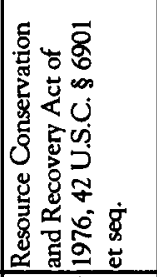 \\
\hline 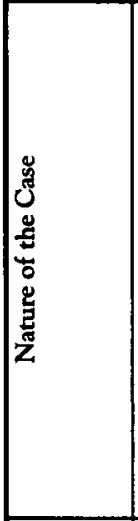 & 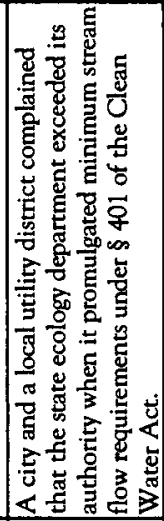 & 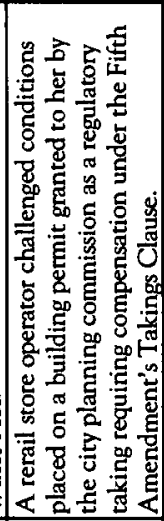 & 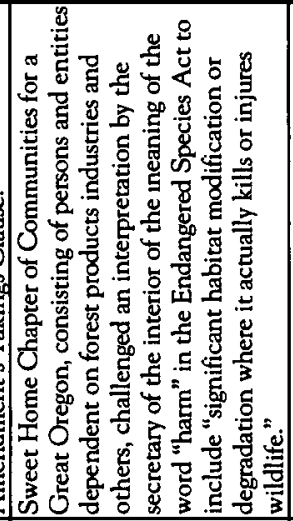 & 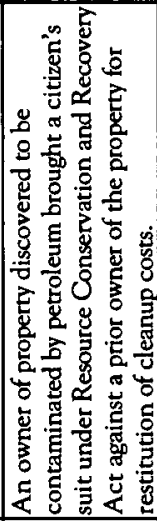 \\
\hline 㐘 & 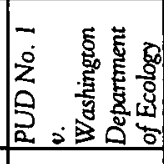 & 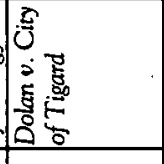 & 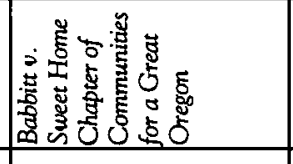 & 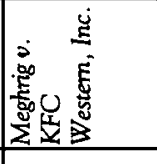 \\
\hline$\mapsto$ & $\approx$ & 2 & \pm & 2 \\
\hline
\end{tabular}




\begin{tabular}{|c|c|c|c|}
\hline 㤣 & 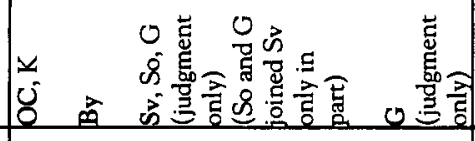 & & \\
\hline & & & \\
\hline & 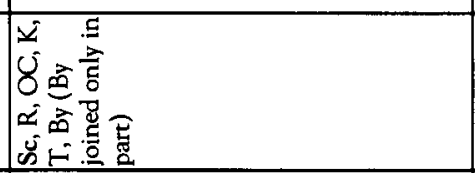 & 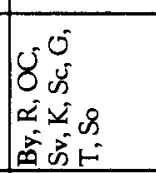 & 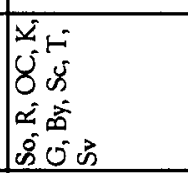 \\
\hline 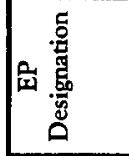 & 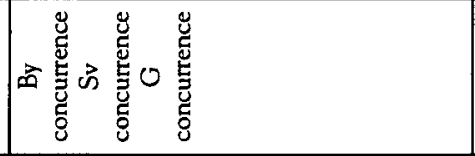 & 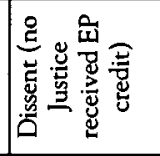 & $\mid \begin{array}{l}\vec{c} \\
\frac{0}{\pi} \\
\frac{\pi}{2}\end{array}$ \\
\hline 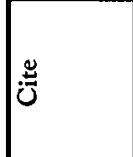 & 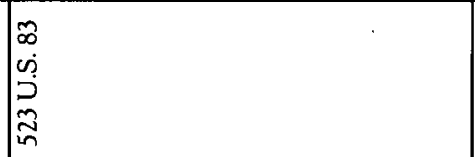 & 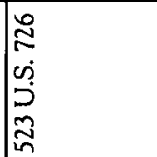 & 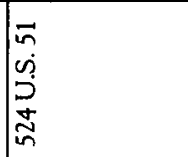 \\
\hline 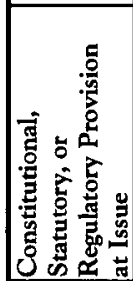 & 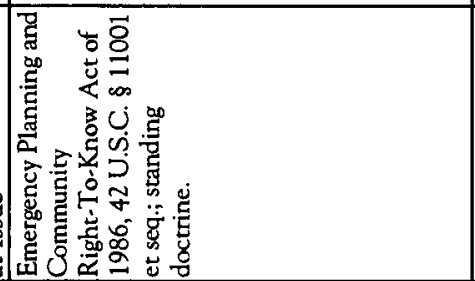 & 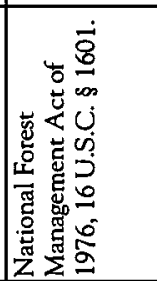 & 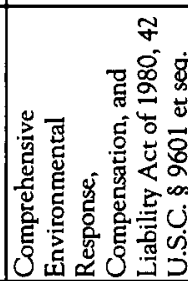 \\
\hline 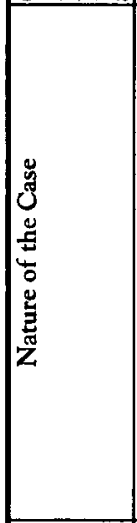 & 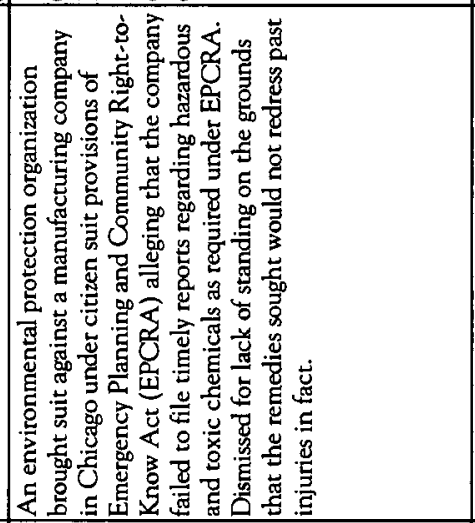 & 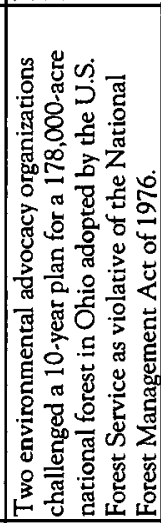 & 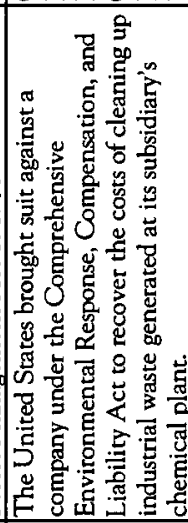 \\
\hline 亗 & 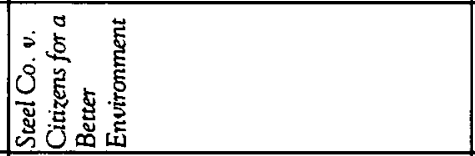 & 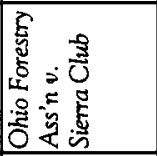 & 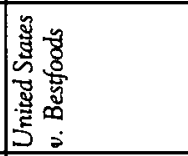 \\
\hline & 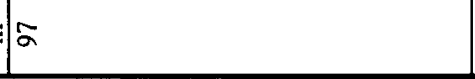 & $\bar{\alpha}$ & a \\
\hline
\end{tabular}




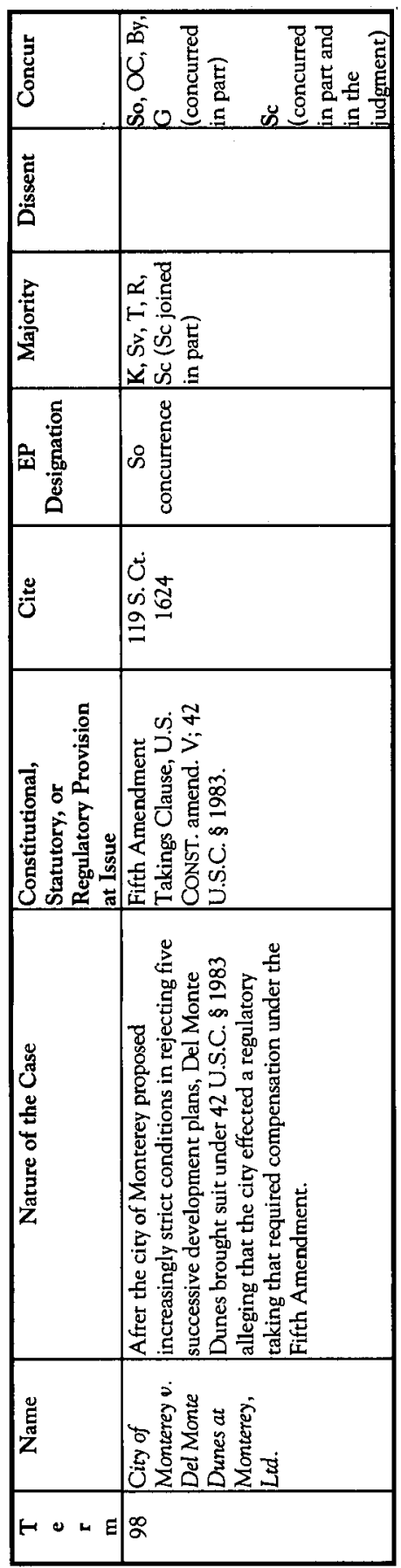




\section{APPENDIX D}

Environmental Cases Decided by the United States Supreme Court October Term 1969-October Term 1998

By Justice-Environmental Protection Scores

\begin{tabular}{|l|c|c|}
\hline \multicolumn{1}{|c|}{ lustice } & $\begin{array}{c}\text { EP Ratio } \\
\text { (\# EP votes/EP cases) }\end{array}$ & $\begin{array}{c}\text { EP Score } \\
\text { (EP Ratio } \times 100)\end{array}$ \\
\hline Black & $3 / 4$ & 75 \\
\hline Blackmun & $56 / 96$ & 58.3 \\
\hline Brennan & $48 / 82$ & 58.5 \\
\hline Breyer & $4 / 6$ & 66.6 \\
\hline Burger & $23 / 67$ & 34.3 \\
\hline Douglas & $15 / 15$ & 100 \\
\hline Ginsburg & $7 / 11$ & 63.6 \\
\hline Harlan & $1 / 3$ & 33.3 \\
\hline Kennedy & $7 / 27$ & 25.9 \\
\hline Marshall & $49 / 80$ & 61.3 \\
\hline O'Connor & $17 / 55$ & 30.9 \\
\hline Powell & $18 / 60$ & 30 \\
\hline Rehnquist & $35 / 96$ & 36.5 \\
\hline Scalia & $5 / 36$ & 13.8 \\
\hline Souter & $12 / 21$ & 57.1 \\
\hline Stevens & $43 / 85$ & 50.6 \\
\hline Stewart & $20 / 47$ & 42.6 \\
\hline Thomas & $4 / 20$ & 20 \\
\hline White & $33 / 91$ & 36.3 \\
\hline
\end{tabular}

